\title{
DEREGULATING LAND USE: AN ALTERNATIVE FREE ENTERPRISE DEVELOPMENT SYSTEM
}

\author{
Douglas W. KMIEC $\dagger$ \\ TABLE OF CONTENTS
}

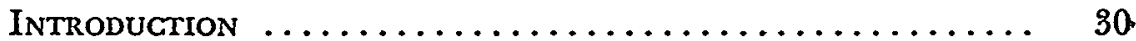

I. The Existing Land Use Allocation System-Structure, Objectives, and Shortcomings .......... 32

A. The Basic Structure of Zoning and Subdivision Law . 34

1. Zoning ........................ 35

2. Subdivision Regulation ............... 36

B. The Objectives of a Land Use Allocation System .... 38

C. The Shortcomings of the Existing System ........ 40

1. Fairness ...................... 40

a. Distributional Fairness .............. 40

b. Procedural Fairness ................ 43

2. Efficiency $\ldots \ldots \ldots \ldots \ldots \ldots \ldots \ldots \ldots \ldots, 46$

3. Flexibility $\ldots \ldots \ldots \ldots \ldots \ldots \ldots \ldots \ldots \ldots \ldots$

a. Zoning in Theory-A Self-Administering System 49

b. Zoning in Practice-Covert Individual Treatment ........................ 51

c. Zoning in Practice-Incapable of Assimilating Rapid Change .................... 52

d. Flexibility Devices Under the Existing System . 53

4. Certainty ..................... 57

a. Existing Uses and Structures Under Zoning ... 58.

b. Uncertain Allocations for Undeveloped Land .. 58

II. An Alternative Free Enterprise Development System 66 .

A. An Outline of the Alternative System .......... 66 -

1. Defining Land Use Intensity ............. 66

2. Selecting LUI Ratings for Specific Parcels ...... 67

3. Public Improvements . . . . . . . . . . . . 69

4. Changing Regulation by Contract ........ 70:

B. An Examination of the Primary Elements of the Alternative System ..................... 70

1. Reclassification of Undeveloped Land to Agricultural/Open Space ................... 71

a. Removal of Hidden Growth Impediments .... 75

b. Increasing Individual Freedom ........... 76

c. Historical Equity .................. 76

d. Additional Benefits of Reclassification ....... 76

๑) Copyright 1981 by Douglas W. Kmiec

† Associate Professor of Law, University of Notre Dame. B.A. 1973, Northwestern University; J.D. 1976, University of Southern California. Member, Illinois. and California Bars. 
2. Redirecting Public Participation Toward Land Use Policy Issues ....................

a. Misuse of Zoning for Private Purposes ........

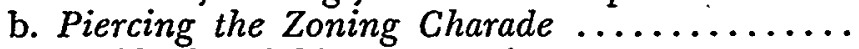

c. Residual Neighbor Protection ...............

d. Protection of the Housing Consumer .........

e. Due Process Objections to Reducing the Neighbor's Role ....................... 87

(i) The Type of Government Proceeding .... 88

(ii) The Nature of the Interest Threatened .. 90

(iii) Judicial Evaluation of Neighbor Property Interests Under the Existing System .....

(iv) Applying Due Process Concepts to the Alternative System ................ 91

3. Regulating Land Use Intensity ........... 93

a. Limiting the Scope of Public Regulation ..... 93

b. Retaining Public Control of Overall Density .. 93

(i) Density Regulation Under the Existing System ..................... 94

(ii) The LUI System ............... 95

(iii) Application of the LUI System to the Alternative System .................. 96

(iv) Landowner Freedom and Influences Thereon $\ldots \ldots \ldots \ldots \ldots \ldots \ldots \ldots \ldots \ldots \ldots$

4. Public Improvement and Intensity Modification Contracts

a. Judicial Hostility to Bargaining Under the Exist-

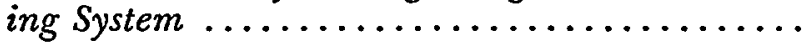

b. Bargained-For Land Use Control Under the Alternative System ....................

(i) Corrupt Behavior ...................

(ii) Improper Contracting Away of the Police

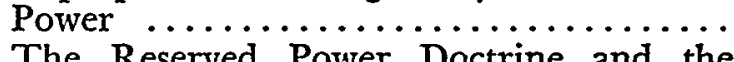

(iii) The Reserved Power Doctrine and the Existing System ...................

(iv) The Reserved Power Doctrine and the Alternative System ................

5. The Unearned Increment: Its Recapture and Use for Public Improvements and General Revenue ..

a. The Property Tax and Public Improvement ...

b. Impact Fees and Construction Taxes .........

c. Arguments Against Unearned Increment Recapture

d. Henry George and the Land Value Tax ......

(i) Recapturing Windfalls and Eliminating

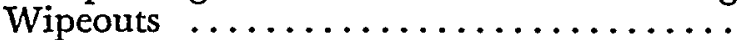

(ii) Land Value Recapture Under the Alterna-

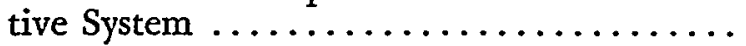




\section{INTRODUCTION}

The satisfaction of human wants has become increasingly dependent upon the use of the land. With special emphasis on undeveloped land, environmentalists advocate preserving land as open space, ${ }^{1}$ farmers demand tax credits and other incentives to keep land in agricultural production, ${ }^{2}$ and families, whose interests often are represented by developers, argue for more and better housing. ${ }^{3}$ Because each use may exclude the others, land use decisions are bitterly fought contests in which the participants expect the end result to be permanent, or in any event, long lasting.

This Article does not focus on the substance of such contests; it advocates neither open space nor farming nor housing. Rather, this Article focuses upon the system through which land use decisions for undeveloped land are made. It posits that a viable system should be fair, efficient, flexible, and certain. The existing land use allocation system founded upon the extensive public control of zoning and subdivision law meets none of these criteria.

In particular, the existing system is procedurally unfair because it unjustifiably accords substantial weight to self-selected samples of neighbors to the detriment of the landowner and the consumers he represents; distributionally unfair ${ }^{5}$ because it arbitrarily

1 On techniques for preserving open space, see Eveleth, An Appraisal of Techniques to Preserve Open Space, 9 VmL. L. Rev. 559 (1964); Krasnowiecki \& Paul, The Preservation of Open Space in Metropolitan Area, 110 U. PA. L. REv. 179 (1961); Note, Techniques for Preserving Open Spaces, 75 HaRv. L. Rev. 1622 (1962). The Supreme Court has sanctioned the use of the police power to preserve open space. See Agins v. City of Tiburon, 447 U.S. 255 (1980).

2 See generally, 5 N. Williams, Amartcan Land Planning Law $\$ 159.10$ (1975); Geier, Agricultural Districts and Zoning: A State-Local Approach to a National Problem, 8 Ecologx L.Q. 655 (1980). For a critique of the benefits of agricultural tax credits, see Roberts, The Big Giveaway Called Differential Assessment: Some Thoughts on the Integration of Tax and Land Use Policy, 2 UnB. L. \& Por'y 65 (1979).

3 The arguments for more housing often are made by developers in the context of attempts to refute the need for local growth control. See Ellickson, Suburban Growth Controls: An Economic and Legal Analysis, 86 YALE L.J. 385 (1977). Both federal and state courts have applied a fairly liberal standing analysis, allowing developers to maintain a suit against restrictive zoning ordinances and outcomes. See, e.g., Village of Arlington Heights v. Metropolitan Hous. Dev. Corp., 429 U.S. 252, 260-64 (1977) (granting developers standing to represent their own interests, but leaving unresolved the question whether developers have standing to represent potential tenants); Home Builders League v. Township of Berlin, 81 N.J. 127, I31-35, 405 A.2d 381, 383-85 (1979) (granting standing to nonprofit developers and to public advocate's office, while rejecting the potentially restrictive view of Arlington Heights).

4 See infra text accompanying notes 57-66.

5 See infra text accompanying notes 46-56. 
favors some landowners while burdening others; inefficient as a mechanism for internalizing harmful spillovers ${ }^{6}$ because it relies upon a system of specific deterrence; inefficient as a mechanism of public control ${ }^{\top}$ because it is fractured among numerous agencies and legislative bodies; inflexible ${ }^{8}$ because it is founded upon predetermined, crude categories of permitted uses unable to accommodate new development techniques, and uncertain ${ }^{\circ}$ because it is subject to changes granted without standards or without adherence to announced standards and without sufficient or consistent regard for investments made in reliance thereon.

Thus, this Article contends that zoning and subdivision controls as presently constituted should be eliminated and replaced by an alternative free enterprise development system ("alternative system") which would allow private decisions to determine the desired type, location, and design of land development. Such an alternative system would confine government to the role of preserving order and fundamental liberties. In the land use context, public control would provide a reasonably safe environment for living and working, but would not impose aesthetic or social preferences.

The alternative system would reduce, but not eliminate, public control over undeveloped land. After consultation with interested members of the public, local governing bodies would establish the overall land use intensity policy for the community.10 Then, by private contract with the developer, an administrative Land Use Control Agency ("LUCA") would define the public-but generally not the private-improvements required for any given development. $^{11}$ Public improvements would be financed largely through the recapture of unearned land value at the time of development. ${ }^{12}$ Beyond this, affirmative public control would not interfere with the personal freedom and private decisions of the individual, except to provide nuisance and other traditional judicial remedies for aberrant private decisions and to enforce private covenants respecting the use of land.

${ }^{6}$ See infra text accompanying notes 67-77.

$\tau$ See infra notes $15-19$ and accompanying text.

8 See infra text accompanying notes 78-101.

- See infra text accompanying notes 102-34.

10 See infra text accompanying notes 135-40.

11 See infra text accompanying notes 141-42.

12 See infra text accompanying notes 304-47. 


\section{The Existing Land Use Allogation System-Structure, OBJectives, AND SHORTcomings}

Land use controls have proliferated within the last fifty years. ${ }^{13}$ Complex land use problems ${ }^{14}$ quickly generated a host of equally complex solutions. Indeed, the progression from the common law of nuisance to detailed building and housing codes, ${ }^{15}$ zoning laws, ${ }^{16}$ subdivision controls, ${ }^{17}$ and environmental impact regulations ${ }^{18}$ has

13 American local municipalities, up until the late nineteenth century, enacted practically no formal land use controls. LaAND Use Controls: Present Problems AND FUTURE REForm 3 (D. Listokin ed. 1974) [hereinafter cited as LaND UsE ControLs]. Unreasonable uses of land were generally regulated through the common law of nuisance. 1 R. ANDERSON, AMERTCAN LAw OF ZONING $\$ 1.02$ (2d ed. 1976).

14 Recognition of the complexity presented by land use issues can be traced to Village of Euclid v. Ambler Realty Co., 272 U.S. 365 (1926), in which Justice Sutherland stated:

Until recent years, urban life was comparatively simple; but with the great increase and concentration of population, problems have developed, and constantly are developing, which require, and will continue to require, additional restrictions in respect of the use and occupation of private lands in urban communities. .. Such regulations are sustained, under the complex conditions of our day....

Id. 386-87.

15 Building and housing codes primarily deal with the material makeup and habitability of a structure; however, they interrelate with other land use controls, such as height and setback provisions, on the issue of safety. See generally 1 P. Rohan, Zoning and LaND USE Controls \$ 1.02[6][c] (1978).

Although building codes can be criticized for excessive specification and inflexibility, the policy of establishing a threshold level of safety cannot be faulted. The alternative system preserves building code regulation, with the general endorsement of the efforts aimed at uniformity and the substitution of performance for specification standards. See infra notes 205-06 and accompanying text.

16 Zoning in America was patterned after the late nineteenth century experience in Germany, and the first comprehensive ordinance was that adopted by New York City in 1916. See I R. Anderson, stpra note 13, \$1.02; 1 J. MetzeNBAUM, LAW OF ZONING 12-15 (1955).

17 Subdivision control began as an attempt to clarify land titles for assessment and conveyancing purposes. See IlLINOIS DEPARTMENT OF LOCAL AFFaIRs, Cittzen's Guide to Subdrvision Regulations 2 (April 1978). Beginning in 1928 with the promulgation of the Standard City Planning Enabling Act (SPEA), U.S. Dep't of Commence, Standard City Planning Enablung Act (1928), reprinted in Moder Land Dev. Code app. B (Tent. Draft No. 1, 1968) [hereinafter cited as SPEA], subdivision control gradually became a substantive land use regulation. Today, subdivision regulation includes a review of site and lot design, street grades, materials, layout, the availability and adequacy of public improvements, and various health matters, such as drainage and waste treatment. See 1 P. Rorin, supra note $15, \$ 1.02[6][a]$.

The major area of controversy in terms of subdivision regulation has been defining what kind of conditions, required dedications, fee payments, and improvements can be imposed for subdivision approval. See D. HaGMan, URBAN PrannING and Land Development Control Law \$138, at 253 \& n.37 (1971). For the alternative system's answer to this thorny problem, see infra text accompanying notes $304-47$.

18 Environmental consciousness in America is often traced to January 1, 1970, the date the National Environmental Policy Act of 1969 (NEPA), Pub. L. No. 
been a staggeringly rapid one. Not surprisingly, many of these controls duplicate, or worse, contradict each other, thus increasing the cost of development. ${ }^{19}$ While the justification and cost of public regulation has frequently been challenged, ${ }^{20}$ land use controls are primarily local in origin, and hence, the challenges themselves have been individual or piecemeal in nature. There have been occasional calls for the total repeal of public controls; ${ }^{21}$ more commonly, how-

91-190, 83 Stat. 852 (codified at 42 U.S.C. $\$ \$ 4321,4331-4335,4341-4347$ (1976)), became effective. Among other things, NEPA requires the preparation of an environmental impact statement (EIS) for major federal actions which may have a significant impact on the environment. Because many major federal actions include construction activity, NEPA is very much a land use control. Moreover, private or state action which involves a federal grant, permit, or decision requires an EIS. See, e.g., Silva v. Romney, 473 F.2d 287 (1st Cir. 1973) (enjoining HUD and private developer from beginning a construction project until an EIS was prepared); Ely v. Velde, 451 F.2d 1130 (4th Cir. 1971) (requiring EIS for award of federal grant to Virginia).

At last count, 19 states have required environmental impact statements under NEPA-like provisions; 7 states have more limited EIS requirements. See CouncI on Envtronmental Quatity, Envtronmental Quality-Eighth AnNual Report 130 (Dec. 1977). While most state statutes are limited to a consideration of government/public works type projects, some have been given broader judicial construction. For example, the California Supreme Court has applied the California Environmental Quality Act to all activities permitted, funded, or regulated by state and local government. Because virtually all private development requires some type of government permit, it now also requires an EIS. See Friends of Mammoth v. Board of Supervisors, 8 Cal. 3d 247, 502 P.2d 1049, 104 Cal. Rptr. 761 (1972) (en banc).

The effect of environmental quality acts has been criticized as taking away limited resources from state and local planning efforts. Moreover, many EIS requirements are viewed as just more "permits" required for development. Thus, EISs are prepared in boiler plate fashion, often redoing much of the work previously incorporated into land use regulation itself. Finally, EIS preparation concentrates on the physical aspects of land development, rather than the social and economic aspects of development which avant-garde planners now think they can identify. See Hagman, Nepa's Progeny Inhabit the States-Were the Genes Defective? 7 URB. L. ANN. 3 (1974).

19 See generally Dowall, Effects of Environmental Regulation on Housing Costs, in D. Hagman, Public Planning and Control of Urban and Land Development 464 (2d ed. 1980).

20 See, e.g., B. StEgaN, LAND USE WrThout Zonang (1972); Ellickson, Alternaitves to Zoning: Covenants, Nuisance Rules, and Fines as Land Use Controls, 40 U. Crr. L. Rev. 681 (1973); Note, Land Use Control in Metropolitan Areas: The Failure of Zoning and a Proposed Alternaitve, 45 S. CAr. L. REv. 335 (1972).

21 Professor Siegan suggests that in the context of undertaking a comprehensive zoning amendment, the zoning ordinance should be repealed in full. "It is common sense, if not planning theory, that if zoning has not worked well in the past and it is not likely to work well in the future, it should be discontinued. Certainly no one would argue that there should be regulation merely for the sake of regulation." B. Stegan, supra note 20, at 232. Similarly, Professor Ellickson has concluded that, "[d]etailed mandatory zoning standards inevitably impair efficient urban growth and discriminate against migrants, lower classes, and landowners with little political influence. The elimination of all mandatory zoning controls on population densities, land use locations, and building bulks is therefore probably desirable." Ellickson, supra note 20 , at 779 . 
ever, efforts have been directed at streamlining or unifying the exist-. ing development control process. ${ }^{22}$

Both approaches are inadequate. So long as land use decisions have spillover or external effects which cannot be internalized through private bargaining, ${ }^{23}$ some form of public control is necessary. To the extent that the manifold existing controls invade areas more properly reserved for private decisionmaking, the streamlining of control addresses merely the cosmetic, rather than the substantive, difficulties of the existing system. Thus, land use reforms have often taken all-or-nothing positions. This Article suggests an alternative system that is not at the extremes. The proposed alternative system would retain public control, but only where private decisionsbecause of inadequate information, transaction costs, or resourceswould not reach an optimal result in terms of an articulated community policy and the maximization of economic resources.

\section{A. The Basic Structure of Zoning and Subdivision Law}

In order to understand when public control should displace private decisionmaking, it is first necessary to examine the structure, objectives, and shortcomings of the existing land use system. Because it would be impossible to analyze the enormous variety of regulation that affects land use, this Article focuses primarily upon the two most important elements of the existing system: zoning and subdivision law.

22 In 1975, the American Law Institute published its Model Land Development Code which attempts to integrate conventional zoning and subdivision control into a unified land development control system. MOder LAND DEv. Code (Proposed Official Draft 1975); see also D. Mandelker \& R. Cunntngram, Plannang and Control of Iland Development 790-91 (1979).

23 All land uses cause positive or negative externalities. An externality is positive when a land use benefits others who do not pay for that benefit; an externality is negative when a land use imposes uncompensated damage or injury on others. Professor Coase has demonstrated that, in the absence of transaction costs, private parties can be expected to eliminate externalities through private bargaining. See Coase, The Problem of Social Cost, 3 J.L. \& Econ. 1 (1960). Whenever private bargaining can occur, the land use that will prevail is determined by the relative value of the competing uses, and not by the assignment of legal rights. See R. Positer, Economic ANALxsis of Law $\$ 3.4$, at 34-35 (2d ed. 1977). An efficient result does not occur in many cases, however, because private bargaining is not costless. ' Specifically, there are frequently substantial organizational, informational, and administrative costs. In this regard, even if the organizational and administrative costs could be overcome, private bargaining often is incapable of reaching an efficient result in respect to resources held in common. See Hardin, The Tragedy of the Commons, 162 ScIENce 1243 (1968); Moore, Why Allow Planners to Do What They Do: A Justification from Economic Theory, $44 \mathrm{~J}$. AM. INST. PlanNers 387 (1978). 


\section{Zoning}

Despite the proliferation of land use regulation, zoning remains the primary element of the system. While there are thousands of local governments exercising the zoning power, ${ }^{24}$ the format of zoning ordinances remains very similar. Most ordinances are based on the Standard State Zoning Enabling Act (SZEA), first issued by the Department of Commerce in 1922 and revised in 1926.25 In general, land uses are geographically separated and placed into categories on a zoning map. The text of a typical zoning ordinance defines permitted and sometimes conditional uses, as well as building size and density of population restrictions, for each category or zoning classification. Usually, zoning ordinances are enforced prospectively by building officials who review specific development plans. To a very limited extent, preexisting land uses which do not conform to the policies stated in the ordinance will be gradually terminated or amortized. ${ }^{26}$

The zoning ordinance is typically drafted by a planning commission, a body of unpaid, unelected, and untrained citizens, which attorney Richard Babcock has described as a "dodo-[which is] neither expert nor responsible." ${ }^{27}$ Public hearings on the draft ordinance are held at the planning stage and again when the local governing body formally considers the draft. The SZEA provides legislative ${ }^{28}$ and administrative ${ }^{29}$ remedies for those disenchanted with the final product.

24 See A. Manvel, Local Land and Bumbing Regulations 23, 31 (National Commission on Urban Problems Research Report No. 6, 1968).

25 U.S. Dep't of Commerce, Standard State Zoning Enabling Act (rev. ed. 1926), reprinted in Modex Land Dev. Code app. A (Tent. Draft No. 1, 1968) [hereinafter cited as SZEA].

26 Frequently, nonconforming uses which predate a zoning ordinance are allowed to continue on restricted terms. See $1 \mathrm{R}$. ANDERson, supra note 13, $\$ \$ 6.32-63$. See infra text accompanying notes 103-06.

27 R. BABCOCK, THE ZoNING GAME 40 (1966).

28 Section 5 of the Standard State Zoning Enabling Act provides for amendment, supplementation, change, modification, or repeal of the regulations, restrictions, and boundaries in the zoning ordinance. SZEA, supra note $25, \S 5$; see $1 \mathrm{R}$. ANDERsoN, supra note $13, \$ \$ 4.25-.37 ; 1$ P. RoHAN, supra note 15 , $\$ 1.02$ [5][b][ii]. For a discussion of zone amendments in relation to the flexibility of the existing system, see infra text following note 88 .

29 The Standard State Zoning Enabling Act authorizes a zoning board of adjustment to grant special exceptions (conditional uses) to the zoning ordinance. SZEA, supra note 25, $\$ 7$; see 3 R. ANDERSON, supra note 13, $\$ 17.07-12 ; 2$ P. RoHAN, supra note 15, $\$ 13.04[2][e]$. For a discussion of the conditional use device in relation to the flexibility of the existing system, see infra text accompanying notes 91-94.

The zoning board of adjustment is also authorized to grant variances from the terms of the zoning ordinance in cases where enforcement would result in un-. 


\section{Subdivision Regulation}

Subdivision regulations have not been enacted with the same uniform character as zoning. Originally, subdivision platting laws were enacted to enhance the accuracy of land descriptions by requiring property to be sold with reference to a recorded plat. ${ }^{30}$ With the drafting of the Standard City Planning Enabling Act (SPEA), ${ }^{31}$ however, subdivision controls began to take on the character of a substantive land use control. Today, subdivision controls are used to specify the quality and extent of on-site improvements such as roads, drainage, and sewage facilities. ${ }^{32}$ In addition, subdivision regulations may require land dedication or equivalent fees for park and school purposes-sometimes without express legislative authorization and generally without compensation..$^{33}$ Off-site dedications, fees, or improvements also may be required if there is some nexus between the proposed subdivision and the improvements. ${ }^{34}$

necessary hardship. SZEA, supra note 25, $\$ 7$; see 3 ANDERSON, supra note 13, $\$ 18.01-04$. For a discussion of the variance mechanism in relation to the flexibility provided by the existing system, see infra text accompanying notes 89-90.

30 Without a plat, property would often be sold informally (and frequently inaccurately) by metes and bounds. See D. Mandelken \& R. CunNingham, supta note 22, at 783; see also supra note 17.

31 SPEA, supra note 17. For a discussion of the SPEA, see D. HAGMAN, supra note $17, \S 21$.

32 In part, the SPEA provides:

Such [subdivision] regulations may provide for the proper arrangement of streets in relation to other existing or planned streets and to the master plan, for adequate and convenient open spaces for traffic, utilities, access of fire fighting apparatus, recreation, light and air, and for the avoidance of congestion of population, including minimum width and areas of lots.

Such regulations may include provisions as to the extent to which streets and other ways shall be graded and improved and to which water and sewer and other utility mains, piping, or other facilities shall be installed as a condition precedent to the approval of the plat.

SPEA, supra note $17, \S 14$ (footnotes omitted).

33 Subdivision regulation has engendered considerable law review commentary. See, e.g., Hanna, Subdivisions: Conditions Imposed by Local Government, 6 SANTA CrARA LAW. 172 (1966); Heyman \& Gilhool, The Constitutionality of Imposing Increased Community Costs on New Suburban Residents Through Subdivision Exactions, 73 YALE L.J. 1119 (1964); Johnston, Constitutionality of Subdivision Contral Exactions: The Quest for a Rationale, 52 Conneli L.Q. 871 (1967); Note, Subdivision Exactions: Where Is the Limit?, 42 Notre Dame Law. 400 (1967).

Where statutory authority is inadequate, the municipality may be able to obtain money for park and school purposes in other ways. For example, a fee may be placed on annexation, City of Colorado Springs v. Kitty Hawk Dev. Co., 154 Colo. 535,392 P.2d 467 (1964) (en banc), or upon the construction business itself, Westfield-Palos Verdes Co. v. City of Rancho Palos Verdes, 73 Cal. App. 3d 486, 141 Cal. Rptr. 36 (1977).

${ }^{34}$ Subdivision dedications and fees may be subject to more than statutory and ordinance limitations. Assuming that one does not accept the fictional notion that subdividing is a privilege upon which a municipality may place any con- 
Finally, subdivision regulations may be used as a mechanism for growth control ${ }^{35}$ or for implementation of a community's master or comprehensive plan. ${ }^{36}$

Subdivision controls are exercised through a series of plat reviews by the local planning commission, the local governing body, or both. Typically, after initial discussions with the planning staff, a developer submits a preliminary plat to the planning commission. The planning commission then circulates the plat to various interested departments for comment. Negotiations between the developer and the planning commission staff at this stage result in approval, disapproval, or conditional approval by the commission. The developer receiving preliminary plat approval must construct any required public improvements, or post a bond guaranteeing construction within a specified time. ${ }^{37}$ When the improvements are certified by the local governing body's engineer, the developer submits a final plat, which must be approved if the preliminary plat requirements have been fulfilled.

dition, see D. HAGMAN, supra note 19, at 904 , subdivision control is an exercise of the police power and, as such, is subject to constitutional limitations.

The courts have considered constitutional limitations on subdivision regulation most often in the context of municipal requirements pertaining to off-site dedications, fees, or improvements-that is, exactions which benefit more than the land subdivided. The courts have developed three tests. In Pioneer Trust \& Sav. Bank v. Village of Mount Prospect, 22 Ill. 2d 375, 176 N.E.2d 799 (1961), the Supreme Court of Illinois invalidated a city-required land dedication of 6.7 acres for an elementary school site and playground because the need for the recreational and educational facilities was not specifically and uniquely attributable to the subdivision. Other courts uphold the off-site exaction if there is a "rational nexus" between the exaction and the "needs created by, and benefits conferred upon, the subdivision." Longridge Builders, Inc. v. Planning Bd., 52 N.J. $348,350,245$ A.2d 336, 337 (1968) (per curiam). Finally, some courts simply defer to the municipal decision concerning how and where to spend subdivision exaction revenue. See, e.g., Associated Home Builders v. City of Walnut Creek, 4 Cal. 3d 633, 484 P.2d 606, 94 Cal. Rptr. 630 (en banc), appeal dismissed, 404 U.S. 878 (1971).

35 See, e.g., N.H. REv. Stat. ANv. \$36:21 (Supp. 1979).

30 See, e.g., Car. Gov't Code $\$ 66418$ (9) (West Supp. 1980); see also Nelson, The Master Plan and Subdivision Control, 16 ME. L. Rev. 107 (1964).

37 See generally Yearwood, Performance Bonding for Subdivision Improvements, 46 J. URB. L. 67 (1968).

In regard to public improvments, the developer may actually be given a number of options. First, the developer may complete construction of all required improvements before submitting a final plat; second, the developer may post a bond guaranteeing such construction; third, the developer may petition a municipality to construct the public improvements and levy the cost against certain lots within the subdivision on a special assessment basis, and fourth, the developer may offer the municipality a mortgage, which will be released as the improvements are constructed. Professors Mandelker and Cunningham suggest that the scope of the range of options made available to the developer will depend upon the community's attitude toward subdivision activity. If the community adopts a no-growth attitude, the options will be limited. See D. Mandenker \& R. CunningHAM, supro note 22 , at 794 . 
The injection of substantive requirements into subdivision controls has bifurcated and lengthened the land use allocation process. Subdivision approval is independent of, and may be inconsistent with, zoning regulation..$^{38}$ Various proposals have been made to integrate the zoning and subdivision process, but to date the trend has been toward adding levels of approvals, rather than toward eliminating or consolidating. ${ }^{39}$

\section{B. The Objectives of a Land Use Allocation System}

Few land use discussions adequately identify the objectives sought to be achieved by proposed allocation systems. Among those questions seldom addressed with sufficient clarity are whether an allocation system should increase public participation at the expense of increased time and costs for development; whether the allocation system minimizes the chance of overlapping regulation; whether the regulation is economically efficient in maximizing the total value of all resources; whether the system can accommodate creative development proposals, and whether the system encourages or at least does not discourage, participation in the development process. This Article will examine all of these questions in detail; it first must be recognized, however, that each of the questions is related to one or more of four ideal characteristics of any land use allocation system: fairness, efficiency, flexibility, and certainty.

An overwhelming amount of scholarly attention has been focused on the fairness issue. ${ }^{40}$ Everyone agrees that the system should

38 D. MANDELKER \& R. CunNinghaM, supra note 22, at 790.

39 There are now numerous local, regional, and state agencies charged with the protection of a specialized aspect of the public weal. Consequently, land development often requires several permits. Moreover, procuring a given permit may be contingent on the completion of the requirements for a previous permit. Regrettably, when development is subjected to multiple permit requirements, economic resources are frequently wasted because compliance with one permit does not vest the right to another. For a particularly dramatic example of wasted resources, see Avco Community Developers, Inc. v. South Coast Regional Comm'n, 17 Cal. 3d 785, 553 P.2d 546, 132 Cal. Rptr. 386 (1976) (en banc), in which the California Coastal Zone Commission denied Avco an exemption from the permit requirement of the California Coastal Zone Conservation Act of 1972, notwithstanding the fact that Avco had spent in excess of $\$ 2$ million in preparatory work, had obtained a grading permit from the county, and had final plat approval. For discussions of the developers dilemma, see Delaney \& Kominers, He Who Rests Less, Vests Best: Acquisition of Vested Rights in Land Development, 23 ST. Lous U.L.J. 219 (1979); Hagman, The Vesting Issue: The Rights of Fetal Development Vis a Vis the Abortions of Public Whimsy, 7 ENvrL. L. 519 (1977) [hereinafter cited as Hagman, The Vesting Issue]; Hagman, Estoppel and Vesting in the Age of Multi-Land Use Permits, 11 Sw. U.L. REv. 545 (1979) [hereinafter cited as Hagman, Estoppel and Vesting].

40 See, e.g., B. Ackerman, Private Property and teee Construtution (1977); Michelman, Property, Utility, and Faimess: Comments on the Ethical Foundations 
be fair or equitable. Few agree, however, on what fairness or equity means in the land use context. Frequently, the issue has been treated as inseparable from the question whether compensation is required for land use regulations which rise to the level of a "taking." 11 While the compensation question is important, it is not the sole determinant of a fair system. As will be seen later, the compensation question is itself merely one aspect of distributional fairness. ${ }^{42}$ In this regard, knowing when a wealth transfer loss precipitated by land use regulation requires compensation is no more, and no less, important than knowing when a wealth transfer gain should be recouped. In addition, even if a system is distributionally fair, it may still be perceived as unfair if the distributional result is arrived at in a procedurally unfair manner.

Efficiency is often considered a desirable end in itself without regard to the objective that is sought to be efficiently obtained. It is important to know what the land use allocation system is expected to do efficiently. As used in this Article, the criteria for efficiency will determine how well the system internalizes harmful spillovers, ameliorates conflicts among neighboring land uses, and reviews land use allocation proposals. In large part, this Article will employ the analysis suggested by Professor Ellickson's groundbreaking article on the subject, characterizing a system as efficient when it minimizes the sum of nuisance, prevention, and administrative costs. ${ }^{43}$

An analysis of a land use allocation system remains incomplete if only fairness and efficiency goals are examined. A land use system must be flexible in order to incorporate new development ideas or policy changes. Recognizing flexibility as an objective of a land use allocation system acknowledges that land development projects increasingly consist of a mixture of theoretically inconsistent land uses. ${ }^{44}$ The series of energy shortages during the past five years

of "Just Compensation" Law, 80 Harv. L. Rev. 1165 (1967); Sax, Takings, Private Property and Public Rights, 81 YALE L.J. 149 (1971) [hereinafter cited as Sax, Takings, Private Property]. Sax, Takings and the Police Power, 74 YAIE L.J. 36 (1964) [hereinafter cited as Sax, Takings and the Police Power].

41 E.g., F. Bosselman, D. Carcies \& J. Banta, The Takms Issue (1973); Berger, A Policy Analysis of the Taking Problem, 49 N.Y.U. L. Rev. 165 (1974); Sax, Takings and the Police Power, supra note 40 .

42 See infra text accompanying notes 46-56.

43 Ellickson, supra note 20, at 688-90.

44 The planned unit development concept under the existing system recognizes this trend. See Babcock, An Introduction to the Model Enabling Act for Planned Residential Development, 114 U. PA. L. Rev. 136 (1965). This type of mixed use development is directly contrary to the rigid districting required by zoning. In a refreshingly honest look at development in the 1980's, Professor Hagman suggests that land use policy include, among other things, mixed use developments. In 
convincingly demonstrates the folly of the traditional land use pattern which totally segregates housing and employment centers. Nonetheless, while mixing business and residential uses may lessen transportation and other energy-related problems, it may accentuate others, such as noise and safety. Thus, an allocation system must be capable of sensitive project-by-project evaluation.

A fourth goal of a land use allocation system should be the provision of certainty. ${ }^{45}$ If land use allocations increase the level of uncertainty, economic resources that ordinarily would be invested in positive production may instead be diverted to adaptive expenditures or not invested at all. For example, when a farmer or housing developer is concerned that his land use allocation will be changed, he may attempt to insure the risk, thereby diverting funds to insurance premiums from farming or housing. Alternatively, because insurance for public regulation is generally unavailable or inadequate, the farmer or housing developer may decide to reduce his investments or, if he is particularly risk averse, may decide not to invest at all.

\section{The Shortcomings of the Existing System}

Having briefly identified the four objectives of the ideal land use allocation system, our focus now turns to an evaluation of how well the existing system, as represented by zoning and subdivision law, accomplishes those objectives.

\section{Fairness}

The fairness issue can be divided into two subissues: distributional fairness and procedural fairness. The division is an analytical one only-if wealth distributions occasioned by the existing system are inherently unfair, then certainly the unfairness is increased if the distribution was derived pursuant to an unfair procedure.

\section{a. Distributional Fairness}

All land use allocations create or destroy land value.48 Two properties with similar physical and locational characteristics may have dramatically different values based solely upon the public designation of a permitted land use. Indeed, landowners often

this regard, Hagman suggests that "[c]ommercial-industrial-residential (CIR) mix facilitates enormous energy savings by making work, shopping and living arrangements less dependent on the automobile." D. HAGMAN, supra note 19 , at 9 .

45 See generally B. Ackerian, supra note 40 , at $44-46$.

46 See infra text accompanying notes 304-47. 
emphasize the existing system's effect on land value to argue for invalidating a particular regulation or to advance a claim for compensation. ${ }^{47}$ Landowner claims of drastic, but not total, diminutions in value, however, have merited neither judicial relief ${ }^{48}$ nor the sympathy of the regulators. ${ }^{49}$

Of course, not all land use designations result in decreased value. More than a few greatly increase land value. This occurs because of the favorable uses or intensity of development permitted under a given land use designation and because participants in the market perceive the scarcity of such designations. ${ }^{50}$

Does the fact that one may just as easily gain as lose as a result of a land use allocation under the existing system mean that the system is distributionally fair? It might, if everyone had an equal chance of gain or loss or if the losers perceived that the particular

47 The landowner's propensity to cite diminution in value as a basis for relief can be traced to the case of Pennsylvania Coal Co. v. Mahon, 260 U.S. 393 (1922), where Justice Holmes stated that "[t]he general rule at least is, that while property may be regulated to a certain extent, if regulation goes too far it will be recognized as a taking." Id. 415.

48 See Village of Euclid v. Ambler Realty Co., 272 U.S. 365 (1926). In Euclid, a 75\% reduction in the value of plaintiff's land caused by a zoning change did not suffice to require the state to compensate plaintiff under the taking clause. U.S. Const. amend. V. The Court has maintained its position that diminution in property value alone cannot justify a taking claim. See Penn Central Transp. Co. v. New York City, 438 U.S. 104, 131 (1978) (citing Euclid); see also HFH, Ltd. v. Superior Court, 15 Cal. 3d 508, 542 P.2d 237, 125 Cal. Rptr. 365 (1975) (en banc) (sustaining a demurrer to an action founded in inverse condemnation when the only alleged effect of the zoning regulation was a diminution in the market value of the property in question), cert. denied, 425 U.S. 904 (1976).

40 Primarily, regulators assert that payment of compensation for the diminution in value caused by police power regulation will have a chilling effect upon the exercise of that authority. One commentator states: "This threat of unanticipated financial liability will intimidate legislative bodies and will discourage the implementation of strict or innovative planning measures in favor of measures which are less stringent, more traditional, and fiscally safe." Note, Eldridge v. City of Palo Alto: Aberration or New Direction in Land Use Law?, 28 Hastings L.J. 1569, 1597 (1977) (footnote omitted). Regulators also assert that a finding of inverse condemnation inappropriately transfers the power of eminent domain from legislatures to the judiciary. See, e.g., Brief for the Califormia Attorney General as Amicus Curiae, Agins v. City of Tiburon, 447 U.S. 255 (1980).

50 See Freeman, Give and Take: Distributing Local Environmental Control Through Land-Use Regulation, 60 MINN. L. REv. 883 (1976). The economic basis for positive externalities, or as Freeman calls them "givings," is a combination of value transfer and supply restriction effects. The value transfer effect derives from the notion that a particular tract of undeveloped land carries with it both a present use value and a component of value equivalent to the discounted value of future development for a particular, more intensive use. Each tract having the potential for more intense development carries a fraction of the total value of one tract already developed for the more intensive use. Thus, "[a] decision to permit development of one of the tracts for the more intensive use would have the effect of removing ... [that fractional value] from the tracts not granted development permission, while at the same time conferring the total of the fractional values on the site designated for development." Id. 965 . 
allocation can reasonably be expected to work out in the long run to the advantage of everyone. ${ }^{51}$ Few land use allocations under the existing system, however, can be characterized as possessing these qualities. Because most land use allocations are legislative matters, ${ }^{52}$ the standard by which they are measured is whether they rationally promote the health, safety, welfare, or morals of the community. This general welfare standard is seldom sufficient to justify why one parcel of land is treated more favorably than another. Absent an adherence to some strict planning methodology, which itself may be neither possible nor desirable, ${ }^{53}$ landowners under the existing system will likely feel that the decisions are arbitrary, or merely the "prizes and penalties of a lottery." $5 \pm$ Thus, the existing system neither requires beneficial property owners to relinquish zoning-created value nor compensates those whose property interests have been devalued. Because the taking jurisprudence of the Supreme Court ${ }^{55}$ and most state courts ${ }^{56}$ ignores the diminution in value caused by land use allocations, absent a showing of

51 This is the fairness test articulated by Professor Michelman. Michelman, supra note 40 , at 1218-24. The suggested fairness standard has been criticized on the basis that few people would have the patience and vision of Michelman's theoretical man. See Berger, supra note 41 , at 185.

52 D. HaGmaN, supra note $17, \S 33$. In order to allow greater judicial scrutiny of the existing system, however, various courts have characterized some zoning actions as "quasi-judicial." See, e.g., Fasano v. Board of County Comm'rs, 264 Or. 574, 507 P.2d 23 (1973) (en banc).

53 Adherence to a planning standard has been required, either judicially or by statute, in a number of states. See, e.g., Baker v. City of Milwaukie, 271 Or. 500, 533 P.2d 772 (1975) (requiring municipalities to implement state comprehensive plan through zoning ordinances); CAI. Gov'T CODE $\$ 65860$ (a)(ii) (West Supp. 1980) (requiring that "[ $t$ ]he various land uses authorized by the [local zoning] ordinance are [to be] compatible with the objectives, policies, general land uses, and programs specified in [the] plan.").

The wisdom of requiring consistency with planning is questionable in view of the inconsistent evidence on the efficacy of planning. In this regard, there is little agreement on the appropriate style of planning, let alone its value. While planning was originally perceived as a way of curing market imperfections, it has seldom been shown to have this effect. Rather, planning "is based upon the assumption that the planner's re-distributive values are superior to those of the market and will result in a net gain to the aggregate welfare . . . [ [P]lanner's choices .... however, risk being arbitrary since planners bear little responsibility for distribution of the costs or benefits of their activity." Tarlock, Consistency with Adopted Land Use Plans as a Standard of Judicial Review: The Case Against, 9 UrB. L. ANN. 69, 76 (1975).

54 Hagman, Windfalls for Wipeouts, in WindFalls For WipeOUTS 20 (D. Hagman \& D. Misczynski eds. 1978).

55 See supra notes 47-48; infra text accompanying notes 149-65.

56 For a discussion of the taking jurisprudence in state courts, see $1 R$. ANDERson, supra note 13, \$3.25; Krasnowiecki \& Strong, Compensible Regulations for Open Space: A Means of Controlling Urban Growth, 29 J. AM. INst. PuANners 87 (1963). 
complete economic nonviability, the distributional unfairness of the existing system is also ignored.

\section{b. Procedural Fairness}

Even though the distributional fairness of land use allocations under the existing system is generally incapable of measurement, the system might be more tolerable if the procedures leading to a "penalty or prize" were fair. Several aspects of the existing system, however, prevent even this modicum of fairness.

Because land use allocations are characterized as legislative in nature, the procedural protections that ensure fairness are limited. While notice is generally provided by statute to affected or interested parties, it seldom is constitutionally required; the members of the hearing body need not be impartial in the sense of having to refrain from ex parte contacts with interested parties or possibly even from being interested themselves; cross-examination is limited, if available at all; most hearing bodies operate without even the loosest set of evidentiary standards, and to compound matters, a record with adequate findings is seldom made to facilitate the limited opportunity for judicial review. ${ }^{57}$

Several jurisdictions have pierced the legislative veil of land use matters, and have found that regulations laying down general policies can be distinguished from regulations affecting the permissible use of a specific parcel of property. ${ }^{58}$ By characterizing these latter

57 See generally Harris, Rezoning-Should it be a Legislative or Judicial Function?, 31 Baycor L. REv. 409 (1979); Sullivan, Araby Revisited: The Evolving Concept of Procedural Due Process Before Land Use Regulatory Bodies, 15 SANTA Crara Law. 50 (1974); Developments in the Law-Zoning, 91 Harv. L. Rev. 1427, 1502-49 (1978); Comment, Zoning Amendments-The Product of Judicial or Quasi-Judicial Action, 33 Ono ST. L.J. 130 (1972).

Neither the SZEA nor the SPEA clearly specifies procedural standards to be used by local governing bodies in making land use decisions. The SZEA specifies certain procedural standards to be followed by local zoning boards of adjustment in the consideration of variances and special exceptions, but the act places virtually no restrictions on the decisionmaking process of the local legislative body. Similarly, the SPEA imposes few procedural restrictions on planning commission determinations.

58 See, e.g., Snyder v. City of Lakewood, 189 Colo. 421, 542 P.2d 371 (1975) (en banc); City of Colorado Springs v. District Court, 184 Colo. 177, 519 P.2d 325 (1974); (en banc); Fasano v. Board of County Comm'rs, 264 Or. 574, 507 P.2d 23 (1973) (en banc); Aldom v. Borough of Roseland, 42 N.J. Super. 495, 127 A.2d 180 (1956).

In Fasano, the Board of County Commissioners rezoned property from single family residential to a planned residential community, which would have allowed the construction of a mobile home park. When this rezoning was challenged by neighboring landowners, the Oregon Supreme Court rejected the previously accepted proposition that judicial review of a zoning amendment was limited to a determination of whether the amendment was arbitrary or capricious. The court distinguished between the exercise of legislative authority involving the laying down of general policies and the judicial determination whether the permissible use of a 
actions as quasi-judicial, these jurisdictions have required some of the due process protections normally associated with judicial proceedings. In addition, the quasi-judicial finding has encouraged the courts to exercise more stringent review of the land use process. ${ }^{59}$

Even if the extension of due process protections to the landowner becomes the prevalent rule, procedural fairness may not be enhanced. As will be discussed later in detail, notions of due process have been used to enlarge public participation in land use matters to include neighbors, policy groups, general taxpayers, and many others only remotely connected with a given property. ${ }^{60}$

specific piece of property should be changed. Having determined that rezoning procedures are judicial in character, the Fasano court concluded that:

Parties at the hearing before the county governing body are entitled to an opportunity to be heard, to an opportunity to present and rebut evidence, to a tribunal which is impartial in the matter-i.e., having had no prehearing or ex parte contacts concerning the question at issue-and to a record made and adequate findings executed.

264 Or. at 588, 507 P.2d at 30; see also Oregon Attorney General's Opinion on Fasano v. Board of County Commissioners, Washington County, No. 7062 (Mar. 26, 1974). In order to carry out the Fasano/due process requirements, two Oregon cities, Eugene and Portland, have shifted responsibility for rezoning hearings from the planning commission to a hearing examiner. The use of a hearing examiner is believed to be beneficial insofar as it lowers the chance of legislative caprice and it promotes the preparation of adequate findings of fact and conclusions of law. See Curtin \& Shirk, Land Use, Planning and Zoning, 9 URB. LAw. 724, 740 (1977).

Nevertheless, "[m]ost courts have been unwilling to treat rezoning decisions as quasi-judicial acts." Sullivan, supra note 57, at 60 . There is some indication, however, that courts in other jurisdictions have created various makeshift devices for informally controlling legislative power, such as the "change or mistake" rule, which invalidates any rezoning unless a change in the physical character of the neighborhood or a mistake in the original zoning can be proved. See $1 \mathrm{R}$. ANDERson, supra note 13, \$5.07; Linowes \& Delaney, The Maryland ChangeMistake Rule: A Mistake That Should Be Changed, 1971 LAND Use Controls ANN. 117.

59 In Fasano v. Board of County Comm'rs, 264 Or. 574, 507 P.2d 23 (1973) (en banc), the court adopted the comprehensive plan as the basic standard for review of land use regulations. In contrast, the SZEA merely requires that zoning regulations be made in accordance with a comprehensive plan. SZEA, supra note $25, \S 3$. The courts have construed that provision "as meaning nothing more than that zoning ordinances shall be comprehensive-that is to say, uniform and broad in scope of coverage. ... [C]ourts have found it difficult to assign any independent meaning to the term." Haar, "In Accordance With A Comprehensive Plan", 68 HARv. L. REv. 1154, 1157 (1955). Thus, for the Fasano court to require substantive corformance with a planning document was a significant judicial departure from prior practice. Moreover, the conformity requirement established by the Fasano court was rigorous:

In proving that the change is in conformance with the comprehensive plan in this case, the proof, at a minimum, should show (1) there is a public need for a change of the kind in question, and (2) that need will be best served by changing the classification of the particular piece of property in question as compared with other available property.

264 Or. at 583-84, $507 \mathrm{P} .2 \mathrm{~d}$ at 28.

${ }^{60}$ See infra text accompanying notes 174-98. 
Under the existing system, then, remote interests are often given the same or more weight as the landowner himself. From the standpoint of democratic theory, widespread public participation may appear salutary, until one realizes that the participating groups are frequently those who have benefited (as homeowners or businessmen) from the existing system in the past, and they are trying to .enhance their "prize" by making sure others are "penalized." Often because the participating groups are residents, and the landowner is not, the participating groups have a decided political advantage regardless of the objective merits of the landowner's proposal. ${ }^{61}$

Finally, the distributional unfairness of the existing system tends to exacerbate the system's procedural unfairness. The effect - of land use allocations on land is often tremendous. The decision may determine the success or failure of a particular project and, perhaps, the economic fate of the landowner himself. Because the - existing system confers the land value prizes and penalties under a standardless lottery, predicting the outcome of a land use controversy is frequently a matter for fortune tellers rather than lawyers. In an effort to reduce the level of investment risk and the chances .of a disastrous penalty, the landowner may be willing to share his land value prize with the decisionmakers. In other words, the . existing system may be corrupt or subject to special influence. ${ }^{62}$

A recently completed study sponsored by the National Institute .of Law Enforcement and Criminal Justice found local government corruption in land use and building regulation to be a significant problem in many areas of the United States. ${ }^{63}$ The study found that land use decisions were particularly susceptible to corruption because of the significant financial losses and gains which are imposed as a consequence of zoning. ${ }^{64}$ Other corruption incentives . cited by the study included the confused treatment of zoning as both a legislative and administrative matter, the increasing complexity of land use procedures, and the lack of standards guiding zoning decisions. ${ }^{65}$ While the study's recommendation that land

61 R. Nelson, Zoning and Property Rrghts 191 (1977). For a discussion of legal remedies available to politically disadvantaged outsiders, see Ellickson, supra -note 3.

62 See Ellickson, supra note 3, at 407-08.

63 Nat'l Institute of Law Enforcement and Crmminal Justice, Law ENForcement Assistance Administratton, U.S. Dep't of Justice, Corruption in LAND USE AND BUILDING REgULATION (1979).

64 Nat'l Institute of Law ENForcement and CrImTnat Justice, Law ENForcement Assistance Admintstration, U.S. Dep't of Justice, An Analysis of ZONIng Reforms: Minamizing the Incentive for Corruption 13 (1979).

65 Id. 7. 
use matters be decided pursuant to a defined administrative procedure and established planning standards may be questioned, little doubt remains that zoning frequently results in untaxed windfalls. or uncompensated wipeouts, where the "friends of the house" enjoy a definite advantage on an imperfectly warped roulette wheel.66

\section{Efficiency}

Strong evidence suggests that the existing system is no more efficient than it is fair. ${ }^{67}$ Any successful reduction in nuisance costs precipitated by the existing system is generally outweighed by increased prevention and administrative costs. ${ }^{68}$ While zoning may reduce nuisance costs by segregating incompatible land uses, the available research indicates that the operation of the land market itself would have accomplished a similar segregation without the corresponding administrative costs. ${ }^{69}$

Several reasons can be cited for the existing system's inefficiency. First, public regulators frequently address only the nuisance cost of the efficiency equation. Consequently, public regulation may attempt to eliminate every conceivable negative aspect of a particular land use, even though such practice may be undesirable from the standpoint of overall economic efficiency. ${ }^{70}$ To use Professor Ellickson's terminology, public regulators seek to minimize

60 Ellickson, supra note 20 , at 701.

67 A prevalent justification for the existing system is to correct market failure. It has been noted that "the existence of market failure is a necessary condition for government intervention." Moore, supra note 23, at 393. As Moore points out, however, the existence of market failure is not a sufficient condition for government intervention, because if the market is operating inefficiently, government intervention may only reduce efficiency. Moreover, even in the presence of market failure, there is little assurance that government intervention will eliminate inefficiency: regulatory intervention may be as flawed as the market.

Economic regulation has been criticized because it is often undertaken without a clear idea of how regulation works. For example, "[m]arket transactions in an unsafe product will often harm third parties without compensation, but the potential for uncompensated, unforeseen harm to consumers, workers, stockholders and other third parties resulting from uninformed economy-wide or industry-wide regulations may be far greater." Schuck, Regulation: Asking the Right Questions, Il NAr'工 J. 711 (1979), reprinted in D. HAGMAN, supra note 19, at 80, 81. Regulatory failure or inefficiency may be even greater in the land use context than in other areas of economic regulation because of the tendency of the existing system to group different land uses into crude, unrefined categories (zoning districts) and to discourage investment and innovation.

68 Ellickson, supra note 20, at 693-99.

e9 Siegan, Regulating the Use of Land, in THE INTERACTION OF ECONOMTCS AND THE LAW 159 (B. Siegan ed. 1977).

70 This is the basic economics notion of diminishing returns. See P. SAMUELson, Economics 21-25 (11th ed. 1980). For a discussion of the concept in the context of environmental regulation, see R. StEWart \& J. KREER, ENVrRonMENTaI. LAW AND POLICX 556-57 (2d ed. 1978). 
-nuisance costs, ignoring the fact that in order to maximize the value of land resources, it is necessary to minimize the "sum of nuisance, prevention, and administrative costs." 71

A second source of the existing system's inefficiency is its reliance upon mandatory specification standards. ${ }^{72}$ For example, zoning frequently mandates that each house in a residential district be set back a specified distance from the street or that certain -commercial establishments, such as all-night grocery stores, be absolutely prohibited in residential zones. While this type of highly collectivized regulation may keep residents free from bothersome noise, lights, and traffic, it also makes it impossible for the landowner to experiment with more creative, and perhaps efficient, solutions to the stated problems. In this regard, the clustering of dwellings to reduce street noise or the use of hedges or lightscreens to reduce the grocery's drawbacks are solutions made impossible by the zoning ordinance. The impossibility of individualized solutions under the existing system is heightened by the system's emphasis upon mandatory compliance orders, rather than fines or taxes, which at least would afford the landowner the freedom of paying a penalty rather than adhering to inefficient standards. Be-cause the design of the existing system is legislative in nature, the courts also have been reluctant to permit zoning by contractual means. $^{73}$

71 Ellickson, supra note 20, at 694 (emphasis added).

72 Performance standards are superior to specification standards for several reasons. First, performance standards prescribe only desired results, leaving to the -discretion of the party being regulated how best to achieve that result. In this regard, the regulator who uses a performance standard recognizes that the regulated party is more likely to have knowledge of efficient solutions than the outside regulator. Second, the use of performance standards prevents regulators from becoming enmeshed in technical subjects for which they do not have any particular expertise. Lastly, performance standards allow for the direct evaluation of both the regulator and the regulated party. The success of specification standards is often measured in indirect terms. For example, zoning is touted as necessary for the .community's "general welfare"; but "general welfare" is too vague to be measured. Consequently, the existing system evaluates its success at increasing welfare through the achievement of specification or process and design requirements-for example, that certain zoning procedures be undertaken or that a subdivision be designed in a particular way. In contrast, performance standards measure the success of the regulation in terms of the actual underlying purpose of the regulation. Perhaps the existing system relies upon specification standards to cloud the fact that its actual underlying purpose may be economic and racial segregation. In this regard, Pro:fessor Hagman's personal prescription for land use policy in the 1980's suggests that: "[I]t will be necessary to purge it from the influence of environmental imposters. These include the elitists, the excluders, the protectors of the status quo, the pseudopantheists and the open spacists (in our backyard at your expense)." D. HAGMAN, supra note 19 , at 6 .

73 For a discussion of contract and conditional zoning, see infra text accompanying notes 250-61. 
The efficiency of the existing system is also undercut by the delays associated with zoning and subdivision administration. ${ }^{44}$ Zoning officials tend to exhibit a lack of concern for permit processing delays. Public regulators are often content to postpone the processing of an application, or debate the merits of a proposed use, or continue discussion from one meeting to the next, seemingly oblivious to the landowner's ever-increasing carrying costs and the impact those costs have on the ultimate quantity and quality of the development.

Theoretically, permit issuance is mandatory if the proposed development is permitted by the existing zoning classifications; however, few developments can proceed today without a zoning variance, amendment, or conditional use permit. ${ }^{\text {T5 }}$ Especially in the case of undeveloped land, zoning officials frequently employ low density holding zones to ensure their ability to exercise discretion over the project. ${ }^{76}$ Subdivision regulations directly afford

i4 Administrative delay has been cited as a significant factor in the cost of housing. See L. Sagalyn \& G. Sternlieb, Zoning and Housing Costs (1973). The response of the existing system to delay has been either to coordinate permit requirements or specify a time limit for decisionmaking. With the advent of state and federal land use controls, however, and the multiplication of permit requirements, especially in the coastal, wetland, and environmentally sensitive areas, coordination has become quite difficult. In addition, local governments may refrain from the coordination procedure if they view it as an attempt by the state to intrude upon local prerogatives. Nevertheless, coordinated hearing legislation has been enacted in Maryland, Alaska, Minnesota, Oregon, and Washington. For an evaluation of such legislation, see F. Bosselman, D. Feurer \& C. Siemon, The Permit Explosion (1976). The Model Land Development Code also provides for joint hearings where multiple permits are required. MODEL LAND DEv. Code, supra note $22, \$ \$ 2-401$ to -403 .

75 Natronal Commission on URban Problems, Lano-Use Controls: Zoninc and Subdivision Regulations, excerpted in LaNd Use Contrors, supta note 13, at 19, 26. The National Commission calls this the "wait and see" approach:

The community obtains de facto control over land development by zoning undeveloped areas for very low densities and then waiting for landowners to seek a map change. The real decisions-perhaps in accordance with an approved plan or prestated policies but more often not-are then taken by the local governing body when each application for rezoning is filed.

Id. 26-27.

76 Professor Nelson states:

Communities have very often held large supplies of land idle or in a relatively low-value use while waiting long periods for high-quality development to be proposed in accordance with their ultimate community design. The cumulative consequence of community zoning in a metropolitan area is a public rationing system for undeveloped metropolitan land. ...

Because of community zoning practices, the supply of metropolitan land made available for high-quality uses has tended far to exceed the demand for these uses, and the supply of land made available for lowerquality uses to be far less than the demand for them. These large im- 
both the planning commission and the governing body considerable discretion in the processing of subdivision plats.

Some states have tried to address the delay costs imposed by the existing system through legislatively defined process times; that is, an application may be deemed approved if not acted on within a specified time unless a continuance is granted with the consent of the landowner. ${ }^{77}$ As a practical matter, however, it is likely that landowners are reluctant to withhold their consent to a continuance for fear that pressing for a reasonable response time may result in outright rejection of their proposed land use.

The efficiency of the existing system is undermined as well by high administrative costs. Public administrative costs include the salaries of zoning and subdivision officials as well as the judiciary involved in reviewing land use decisions. Private administrative costs may be even more extensive. The preparation of a zoning or subdivision application often requires the expensive services of lawyers who specialize in land use law, civil and traffic engineers, architects, planners, consultants, and influence peddlers. Moreover, to the extent that the existing system is subject to special influence, legal campaign contributions or their illegal equivalents must also be counted as administrative costs.

\section{Flexibility}

\section{a. Zoning in Theory-A Self-Administering System}

Zoning was not designed as a flexible land use allocation system. ${ }^{78}$ The Standard State Zoning Enabling Act originally provided for a few zone classifications with large quantities of land within each zone. With the exception of single family zones, zones were cumulative, and zoning architects believed that virtually any use could be accommodated within an existing zone map. At most, the zoning architects thought, extraordinary cases or cases of particular

balances between supplies and demands have caused very serious social inequities and major inefficiencies in the use of metropolitan land.

R. NELSON, supra note 61 , at 187 .

77 For example, California has legislation mandating decisions on development projects within time periods ranging from six to eighteen months. Car. Gov'T CODE $\$ \$ 65950-65954$ (West Supp. 1980).

${ }^{78}$ See Krasnowiecki, Planned Unit Development: A Challenge to Established Theory and Practice of Land Use Control, 114 U. PA. L. Rev. 47, 63 (1965) [hereinafter cited as Krasnowiecki, PUD]; see also Krasnowiecki, The Basic System of Land Use Control: Legislative Preregulation v. Administrative Discretion, in The New Zoning: Legal, Admonistrative, and Economic Concepts and TeghaIQUES 3 (N. Marcus \& M. Groves eds. 1970) [hereinafter cited as Krasnowiecki, The Basic System]. 
hardship could be handled with a minimum of legislative or administrative discretion with a rare zone amendment or variance.

Zoning's inflexibility resulted not only out of a naive optimism concerning the system's workability, but also from the fear that toomuch discretion would lead to unbridled legislative or administrative interference with the land market. While the advent of zoning was certainly part of the trend toward increasing government regulation of economic activity, ${ }^{79}$ its formulation occurred at the beginning of that trend,,$^{80}$ and thus reflects a type of transitional hesitancy against intruding too greatly into areas previously viewed as matters. of private concern. ${ }^{81}$

The desire for a self-administering zoning system coincided well with the low profile of the judiciary in the post-Lochner $v$. New York ${ }^{82}$ era. Most courts have no desire to become enmeshed in land use controversies as a super-zoning body. ${ }^{83}$ Thus, courts look with favor upon a prestated system of regulations which can be easily assessed as to its minimum rationality; conversely, courts have invalidated zoning systems which overtly permit discretion that increases or complicates judicial review. ${ }^{84}$

79 Early zoning can be traced to Los Angeles. In 1909, Los Angeles adopted an ordinance dividing the city into industrial and residential districts. Another Los Angeles ordinance was passed in 1910 which excluded brick factories from one or two of the existing industrial districts. The 1910 ordinance was upheld in Hadacheck v. Sebastian, 239 U.S. 394 (1915). As in most land use matters, the east ultimately caught up with the west, and New York City enacted a zoning ordinance in 1916, which established three separate classes of districts regulating the use, height, and percentage of lot occupied. The three use districts were residential, business, and unrestricted. See S. Tolr, Zoned AMerican 74-187 (1969); supra note 16.

80 See generally J. Nowak, R. Rotunda \& J. Young, Constitutionar Law (1978), in which the authors state: "Beginning in the Spring of 1937 the Court began to defer to the other branches of government in matters of economics and social welfare. No longer would substantive due process and equal protection be used to overturn laws which interfered with traditional views of economic freedom." Id. 149 (footnote omitted). Zoning, of course, was upheld as constitutional in Euclid v. Ambler Realty Co., 272 U.S. 365 (1926).

81 The traditional hesitancy is reflected by the omission of any reference to nonconforming uses in the SZEA. The draftsmen of the early enabling statutes apparently feared that state legislatures would enact zoning provisions which intruded too greatly upon the rights and practices of existing property owners. See E. BAssetr, Zoning 108 \& n.1 (rev, ed. 1940).

82198 U.S. 45 (1905). Lochner invalidated maximum hour legislation and is often cited as the high-water mark of the Court's use of substantive due process analysis to invalidate economic and social regulation.

83 Krasnowiecki, PUD, supra note 78 , at 64 .

84 See Rockhill v. Township of Chesterfield, 23 N.J. 117, 128 A.2d 473 (1957), in which the court invalidated a zoning ordinance that provided for normal agricultural and residential uses and the balance of other uses as special uses, subject to administrative discretion. The court found the "nondistrict" zoning ordinance to be ultra vires of the enabling statute and the very antithesis of zoning, 
While trading flexibility for self-administration might have been acceptable in a world where land use was not the subject of intense social conflict and pressure, that trade-off is hardly acceptable today. The energy, environmental, and housing demands placed upon a land use allocation system today highlight the folly of attempting to reconcile these conflicting and ever-changing demands with any set of prestated rules.

\section{b. Zoning in Practice-Covert Individual Treatment}

Zoning in actual practice has never really been self-administering. In spite of what courts may believe, most zoning of undeveloped land is not a realistic appraisal of what land use is planned, likely, or even compatible with surrounding existing uses. Rather, zoning is used as a device for deferring these difficult decisions. Undeveloped land is either underzoned in unintensive, and generally uneconomic, uses or overzoned in economic, but unrealistic, uses. ${ }^{85}$ For example, substantial undeveloped land is zoned agricultural, not because the land is adequate, or even suitable, for farming, but because the classification represents a nondecision-a choice less controversial than a classification favoring housing over the environment or vice versa. Similarly, undeveloped land may be zoned industrial, which if so developed would enhance the locality's tax base or employment opportunities, but which will not be developed industrially because the land is located far from transportation centers or water resources.

This under/over zoning charade serves to perpetrate the myth that zoning is self-administering. As noted earlier, so long as the land use regulations appear to be predefined, courts are less likely to interfere with the zoning system. Thus, unrealistic classifications not only keep bothersome constituents at bay, but also ensure that the courts will not be too quick to lend an ear to issues that have been "deafly" treated by the zoning body.

notwithstanding the fact that the enabling statute in New Jersey did not require dividing the municipality into districts. Accord Marshall v. Village of Wappingers Falls, 28 A.D.2d 542, 279 N.Y.S.2d 654 (1967); Eves. v. Zoning Bd. of Adjustment, $401 \mathrm{~Pa} .211,164$ A.2d 7 (1960); see also Haar \& Hering, The Lower Gwynedd Township Case: Too Flexible Zoning or an Inflexible Judiciary?, 74 HARv. L. REv. 1552 (1961).

85 See generally D. HAGMAN, supra note 17, $\$ 57,64$; Comment, Stop-Gap and Interim Legislation, A Device to Maintain the Status Quo of an Area Pending the Adoption of a Comprehensive Zoning Ordinance or Amendment Thereto, 18 Syracuse L. REv. 837 (1967). For a discussion of the economic effects precipitated by zoning's inconsistency with market forces, see B. SIEGAN, supra note 20, at 121. For a case illustrating overzoning to bar residential development, see Corthouts v. Town of Newington, 140 Conn. 284, 99 A.2d 112 (1953). 
A more charitable explanation of the under/over zoning phenomenon suggests that it is a mechanism by which zoning officials. "individualize" land use regulations. While individualized land use allocation is desirable, a sub rosa system of individualized land. use standards is unsatisfactory because it almost certainly leads to unfair and inefficient allocation practices; these practices, in turn, are immune from judicial review because of the artificial appearance of a self-administering set of zone classifications. ${ }^{86}$ Under the existing zoning system, covert individualized standards may also be inadequate because zoning officials are fearful of the exercise of individual control in a covert manner.

\section{c. Zoning in Practice-Incapable of Assimilating Rapid Change}

Insofar as the existing system is premised on predesignated zones, it quickly becomes obsolete and inaccurate as an allocation basis. Moreover, any planning that is antecedent to zoning also is likely to form a static constitution incapable of assimilating rapid changes in design, technology, or community preferences. ${ }^{87}$ Planners themselves have perceived the inflexibility of comprehensive plans and zoning maps and have suggested greater reliance upon dynamic planning. ${ }^{88}$ While dynamic planning may prove to be more re-

86 See Krasnowiecki, The Basic System, supra note 78, at 5-6.

87 Siegan cites the development of the fast food franchise industry as an example. Today, these franchises are a major source of demand for strip commercial property. But " $[i] \mathrm{n} 1946$, or 1957 , or 1965 , when the last comprehensive zoning amendments were adopted in Los Angeles, Chicago, and Dallas, respectively, the food franchise operation was either unknown to many or of minor significance." B. SIEGAN, supra note 20 , at 124 . Siegan concludes that " '[u]nderzoning" or 'overzoning' is a normal product of land use regulation, since it is impossible for the amalgamation of planners, politicians, citizens, and courts to determine for any one or more periods the 'right' amount of zoning allocations over the large territories involved." Id.

Professor Freilich has observed that the inability of zoning to remain current and flexible has resulted in the widespread use of interim zoning controls. See Freilich, Interim Development Controls: Essential Tools for Implementing. Flexible Planning and Zoning, excerpted in LAND USE ConTrous, supra note 13, at 213.

88 For example, the Model Land Development Code places greater reliance upon dynamic rather than end-state planning. Section 2-211 prevents development of areas specially planned until a precise plan has been adopted. MODEL LAND DEv. CoDE, supra note $22, \$ 2-211$. Although planners have employed a great variety of styles over time, from end-state master planners to policy and advocate planners to technocratic planners, there is considerable emphasis today on strategic incrementalism-that is, concern with short range strategies and special purpose plans. See Bowden, Hurdles in the Path of Coastal Plan Implementation, 49 S. CAx. L. REv. 759 (1976); see also Reps, The Future of American Planning: Requiem or Renaissance?, 1 LAND-UsE CoNTROLs 1 (1967).

While planners have changed their methods to reflect their inability to predict the future, most statutory planning requirements have not made a similar revelation. See, e.g., GaI. Gov'T CoDE $\$ 65300$ (West 1966) (mandating the preparation of general plans at the local level); Fra. Stat. ANN. $\$ 163.3177$ (West Supp. 
sponsive to preference changes, it is hard to see how a continuously updated plan or zoning map will be any more capable of evaluating new construction techniques or materials or unusual designs that are particularly well-suited to the specific topographical features of a given parcel. Moreover, because planning on an individual or dynamic basis admits that the future is unpredictable, there seems little reason to prefer it over the individual decisions of the marketplace.

\section{d. Flexibility Devices Under the Existing System}

Once zoning classifications are established, they are presumed valid. As noted earlier, the presumption of validity accorded zoning classifications frequently shields zoning from any meaningful judicial review. Thus, a judicial challenge to a zone classification on the basis of its inflexibility is almost certain to fail.

The traditional method for infusing flexibility into the existing system is to seek one of the standard forms of zoning relief, such as a zone amendment, variance, or conditional use. Less traditional methods, such as the planned unit development or contract zoning. may also exist.

Limited flexibility is provided by the zone amendment device largely because the preconditions of amendment accept as valid the prestated nature of the zoning system. Moreover, zone amendments, like zoning itself, are generalizations: apartments in general detract from the value of single family homes; strip commercial development in general is ugly and a source of traffic hazards. The fact that a particular development proposal for an apartment complex may preserve open space and thereby enhance a surrounding single family neighborhood is ignored by the zoning process. The fact that a strip commercial development utilizes an attractive design and may reduce energy consumption cannot be factored into. a zoning system, either initially, or by subsequent amendment.

Variances also supply limited flexibility to the existing system. By express design, ${ }^{89}$ however, variances are intended to permit only

1981) (same). The political difficulty in switching from the master plan concept to a planning process is discussed in Catanese, Plan? or Process?, Planning, June 1974, at 14. The article describes the considerable opposition to proposed Hawaiian legislation that would have provided planners with the freedom necessary to undertake the planning process without being constrained by specific legal descriptions of the plan and its contents. Although consistent with contemporary planning theory, the Hawaiian legislation was opposed because it would not have bound the government to a fixed set of policies and rules.

89 The SZEA provides that variances are to be granted only when the overall purposes of the zoning ordinance can be observed and where exceptional circum- 
minor departures from the building size, and more rarely, the use requirements of a zoning ordinance. While originally intended for cases of unreasonable hardship or practical difficulty, variances often are freely granted by lay administrators without adequate findings supporting the grant. ${ }^{90}$ Nevertheless, the variance is incapable of supplying the flexibility needed for mixed-use projects or other creative development proposals unanticipated by the zoning ordinance.

Another mechanism which provides some zoning flexibility is the conditional use or special exception. Unlike the zone amendment or variance, the conditional use does not provide "relief" from the zoning ordinance in a technical sense. Rather, particular types of uses are expressly made conditional on certain standards contained in the ordinance because they are believed to pose unusual regulatory problems. ${ }^{01}$ For example, nursing homes, hospitals, churches, schools, and other institutional uses are often treated as conditional uses because they are desirable in or near residential areas, but may possess features that are believed to be incompatible with residential use.

The flexibility provided by the conditional use obviously is limited in a number of ways. First, it only applies to a few selected uses. Second, even these uses are only permitted if the specific

stances exist. SZEA, supra note $25, \oint 7$. Because the statutory language suggests that variances are only appropriate for "minor departures," some courts refuse to allow use variances or variances for large parcels. See, e.g., Josephson v. Autrey, 96 So. 2d 784 (Fla. 1957) (en banc).

00 See, e.g., Dukeminier \& Stapleton, The Zoning Board of Adiustment: A Case Study in Misrule, $50 \mathrm{KY}$. L.J. 273 (1962); Shapiro, The Zoning Variance Power-Constructive in Theory, Destructive in Practice, 29 MD. L. REv. 3 (1969); Note, The Effect of Statutory Prerequisites on Decisions of Boards of Zoning Appeals, I IND. LEGAL F. 398 (1968).

Professor Hagman states that "an attorney should seek [a variance] for a client if practice dictates it will be approved, regardless of the law." D. HAGMAN, supra note $17, \$ 106$, at 197 .

${ }^{01}$ A good explanation of the conditional or special use can be found in the opinion written by Judge Hall in Tullo v. Township of Millburn:

The theory is that certain uses, considered by the local legislative body to be essential or desirable for the welfare of the community and its citizenry or substantial segments of it, are entirely appropriate and not essentially incompatible with the basic uses in any zone (or in certain particular zones), but not at every or any location therein or without restrictions or conditions being imposed by reason of special problems the use or its particular location in relation to neighboring properties presents from a zoning standpoint, such as traffic congestion, safety, health, noise, and the like. ... Without intending here to be inclusive or to prescribe limits, the uses ... treated [as conditional uses or special exceptions] are generally those serving considerable numbers of people, such as private schools, clubs, hospitals and even churches, as distinguished 
conditions of the zoning ordinance are met. Third, the location of these uses is frequently limited to a few preconceived zones. Thus, the conditional use is really nothing more than tentative zoning.

This limited flexibility is illustrated by the unsuccessful attempts of communities to make the device the centerpiece of a zoning ordinance. ${ }^{92}$ In one case, a New Jersey township zoned the entire township residential or agricultural, with other uses permitted by conditional use or special exception..$^{98}$ The court found this to be an abuse of the special exception device contrary to the districting requirement of the New Jersey Zoning Enabling Act. Regrettably, the court overlooked that the enabling act permitted, but did not require, districting. ${ }^{94}$ The court was so committed to normal district zoning that it could not conceive of any other way in which development could take place.

The amendment, variance, and conditional use are zoning's traditional mechanisms for providing flexibility. Because these have failed to provide the flexibility needed to evaluate development proposals, other devices have been fashioned. Only one, the planned unit development (PUD), has provided any meaningful departure from zoning's rigid framework. ${ }^{95}$ The PUD is a technique that allows particular consideration of an entire development project, rather than the application of generalized standards to individual lots. As a result, traditional notions of lot setback, side yard, and minimum lot size give way to a more sensitive evaluation of physical relationships.

from governmental structures or activities on the one hand and strictly individual residences or businesses on the other.

54 N.J. Super. 483, 490-91, 149 A.2d $620,624-25$ (1959). The alternative system proposed in this Article retains the conditional or special use mechanism for uses like those described by Judge Hall.

92 See generally Amebergh, The Functions and Duties of $a$ Board of Zoning Adjustment, I INst. ON PLAN. \& ZoNING 109 (1960); Craig, Particularized Zoning: Alterations While You Wait, I Inst. on Pran. \& Zonang 153 (1960); Mandelker, Delegation of Power and Function in Zoning Administration, 1963 WASE. U.L.Q. 60 .

93 Rockhill v. Township of Chesterfield, 23 N.J. 117, 128 A.2d 473 (1957); see also People v. Perez, 214 Cal. App. 2d Supp. 881, 29 Cal. Rptr. 781 (1963).

94 At the time of the case, the New Jersey Zoning and Enabling Act, N.J. STAT. ANN. \$40:55-30 (West 1967) (repealed 1975), was practically identical to the Standard State Zoning Enabling Act providing that "the Iocal legislative body may divide the municipality into districts of such number, shape, and area as may be deemed best suited to carry out the purposes of this act." SZEA, supra note $25, \$ 2$ (emphasis added) (footnotes omitted).

95 Babcock, supra note 44; Craig, Planned Unit Development as Seen From City Hall, 114 U. PA. L. Rev. 127 (1965); see Krasnowiecki, Legal Aspects of Planned Unit Development in Theory and Practice, in Frontrens of PLanned Untr Deveropment 99 (R. Burchell ed. 1973). 
Developers have been attracted by the PUD's flexibility. ${ }^{96} \mathrm{~A}$ PUD permits a developer to plan and market a development as a cohesive neighborhood, often resulting in utility and road extension cost-savings as well as a greater allowance for common open space and recreational areas. In addition, PUD flexibility may extend beyond density and design to the type of permitted use, allowing not only a mixture of housing types, but also a controlled mixture of residential, commercial, and industrial uses.

Why, then, has not the PUD process become the main road with traditonal zoning the less encountered by-way? Primarily, this is because the PUD process in most cases was grafted onto the incompatible zoning system.97 That the two allocation systems were incompatible was recognized early by a number of state courts that found the PUD to be beyond a state's enabling legislation. ${ }^{88}$ Courts were uncomfortable approving the PUD concept because it was difficult to characterize the system as a zone amendment, conditional use, or variance. ${ }^{90}$ None of these traditional zoning procedures, however, was particularly well-suited to the PUD concept. Developers found that because several zoning functions were involved, no single body had the authority under the existing system to approve a given PUD proposal. ${ }^{100}$ Moreover, because zoning

96 See Lloyd, A Developer Looks at Planned Unit Development, 114 U. PA. L. Rev. 3 (1965); see also Clark, Unified Development Controls, or Greater Flexibility in Zoning, 16 Zonswg Dig. 265 (1964).

97 See generally Aloi, Legal Problems in Planned Unit Development: Uniformity, Comprehensive Planning, Conditions, and the Floating Zone, 1 REAL EsT. L.J. 5 (1972).

9s See D. Hagman, supra note 17, $\$ 236$ (citing cases). Particularly troublesome to the courts that first considered the planned unit development was the traditional requirement that zoning be uniform within a given zone. A number of courts inferred that uniform regulation meant only one type of use within any given district. Hence, mixed uses seemed inconceivable. See F. So, D. MosenA \& F. Bangs, Planned Untr Development Ordinances 48 (American Society of Planning Officials Report No. 291, 1973). Other courts had little difficulty in overcoming the uniformity requirement. See, e.g., Orinda Homeowners Comm. v. Board of Supervisors, 11 Cal. App. $3 d$ 768, 90 Cal. Rptr. 88 (1970).

99 See D. Mandelker \& R. Cunningham, supra note 22, at 863.

100 By its very nature, PUD is a discretionary, flexible device. Hence, it is not unusual to find a considerable amount of bargaining in the PUD process. When more than one local land use control agency superintends PUD approval, however, the bargaining process can become complicated. For example, the bargain that appeased the planning commission may not be acceptable to the legislative body or vice versa. The courts are divided on the respective roles of the local legislature and the planning commission in the PUD process. Compare Millbrae Ass'n for Residential Survival v. City of Millbrae, 262 Cal. App. 2d 222, 69 Cal. Rptr. 251 (1968) (substantial changes in a planned development zone cannot be made without legislative action) with Cheney v. Village 2 at New Hope, Inc., 
-officials often perceive the PUD as a gift of regulatory freedom, it is not unusual to find detailed design and improvement standards imposed.101 Thus, PUD flexibility tends to exist in theory, but not in practice. Futhermore, it should not be forgotten that treating the PUD within the standard zoning framework infects the PUD concept with all the unfairness and inefficiency of the existing system.

\section{Certainty}

The fourth goal of a land use allocation system should be certainty. Certain or stable land use allocations encourage initial investment as well as the recoupment of that investment. In addition, certainty may act as an incentive to more extensive planning and design by eliminating the fear that the applicable land use regulations will be altered in an adverse manner..$^{102}$

$429 \mathrm{~Pa} .626,241$ A.2d 81 (1968) (the planning commission is the singularly appropriate body to make PUD decisions).

Some of the difficulties in handling planned unit developments under conventional enabling legislation prompted the drafting of a Model Planned Unit Development statute. See Babcock, Krasnowiecki \& McBride, The Model State Statute, 114 U. PA. L. Rev. 140 (1965). The model statute authorized a single approving agency at the local level to issue a unitary permit for PUDs. The model act has not received overwhelming acceptance among the states. Professor Mandelker notes that six states, including Connecticut, New Jersey, and Pennsylvania, have enacted legislation based on the model act. D. MANDELKer \& R. CunNongham, supra note 22, at 885. For a discussion of the problems associated with drafting planned unit development ordinances, see Sternlieb, Burchell, Hughes \& Listokin, Planned Unit Development Legislation: A Summary of Necessary Considerations, 7 Unb. L. ANN. 71 (1974).

101 To the extent that PUDs become laden with detailed requirements, the mechanism becomes as, or more, inflexible than traditional land use controls under the existing system. Krasnowiecki, Legal Aspects of Planned Unit Development in Theory and Practice, in Land Use Controls, supra note 13, at 185, 192. In fact, the discretion inherent in the PUD concept can be used as a device to exclude unwelcome racial or economic groups. See, e.g., Oakwood at Madison, Inc. v. Township of Madison, 72 N.J. 481, 371 A.2d 1192 (1977) (township directed to remove all cost generating features of the PUD ordinance).

Professor Williams has commented that:

The existence of such a bargaining system [under the PUD concept] may prove to be a heaven-sent opportunity for a municipality to evade judicial strictures against exclusionary zoning, and to strike a cooperative pose, always ready to do something about critical needs-if only the perfect proposal would come along-but always in fact retaining a veto, and so always able to avoid any real action.

$2 \mathrm{~N}$. WILLIAMS, supra note $2, \$ 48.02$, at 229 . Moreover, whether the details added on PUD approval have any substantive merit is questionable. Today the laymen of the planning commission define the details of development to an extent never contemplated as part of the zoning function. See B. SIEGAN, supra note 20 , at 156 .

102 Hagman, The Vesting Issue, supra note 39. Professor Hagman attributes much of the uncertainty in the existing system to the late vesting rule. The concept of vesting refers to the point in the development process when the developer is immune from a change in land use regulation. In general, a developer is not 


\section{a. Existing Uses and Structures Under Zoning}

The existing system attempts to advance the certainty goal insofar as zoning applies prospectively to existing uses and structures. For example, most zoning ordinances contain a provision exempting, either totally or in part, land uses that predate the

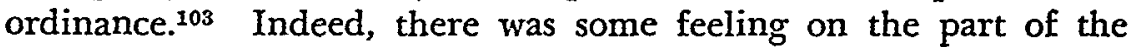
drafters of the SZEA that any attempt to apply zoning to existing land uses and structures without compensation would have been found unconstitutional. ${ }^{104}$ Whether or not that opinion was accurate, the protection of pre-existing nonconforming uses and structures today is not absolute. Generally, ordinances limit the growth of nonconforming uses by placing limits on the owner's ability to. extend the nonconforming use to other parcels, to repair or modify nonconforming structures, or to continue the nonconforming use after it has been abandoned. ${ }^{105}$ Recognizing that noconforming uses. have not "withered away," some communities have limited the nonconforming use even more by enacting amortization provisions that terminate such uses and structures without compensation after a given period of time..$^{108}$

\section{b. Uncertain Allocations for Undeveloped Land}

Thus far, the analysis has concentrated on the certainty provided by the zoning system to owners of existing uses and structures. When the focus shifts to prospective development, the existing system provides even less certainty. It has become axiomatic that an

safe until substantial work has been performed, or liabilities incurred, in good faith reliance upon a building permit. Professor Hagman criticizes this late vesting: rule:

[W]hile the present late vesting rule may eliminate development starts, such elimination is not without a "chilling" effect on desirable development which might otherwise occur and the opportunity for reconsideration of such matters is costly. Furthermore, starts may not actually be eliminated, and even if they are, the starts may be more, rather than less intensive, thus making restoration more difficult while wasting investment dollars.

Id. 539 .

1031 R. ANDERSON, supra note $13, \$ 6.04 \&$ n.43.

104 'Thus, the drafters' intent was not to provide certainty, but to insure the legitimacy of zoning. Indeed, it was expected that nonconforming existing uses ultimately would disappear, rather than continue. See Young, City Planning and Restrictions on the Use of Property, 9 MINN. L. Rev. 593, 628 (1925).

105 D. MANDELEJER \& R. CunNINGHAM, supra note 22, at 292.

106 See Katarincic, Elimination of Non-Conforming Uses, Buildings, and Structures By Amortization-Concept versus Law, 2 DuQ. L. REv, 1 (1963); Norton, Elimination of Incompatible Uses and Structures, 20 LAw \& CoNTEMP. PROBS. 305 (1955); Wood, Zoning Ordinances Requiring the Termination of a Nonconforming Use, 1973 Inst. on Plan. ZonIng \& EMINENT Doman 65. 
owner does not have a vested right in the zoning classification existing at the time of acquisition. ${ }^{107}$ Obviously, this axiom runs directly counter to the prestated nature of the zoning map and any notion that the zoning ordinance should be self-executing. Nevertheless, the axiom has been tolerated in order that zoning officials not be "chilled" in the exercise of their authority, ${ }^{108}$ even if that means the promulgation of an entirely different or inconsistent policy from that reflected in the zoning ordinance. The frequency with which zone amendments, conditional uses, and variances are granted undermines any notion that zoning officials have been "chilled." 109 In fact, these frequent departures from the zoning ordinance often are granted improvidently because of the absence of meaningful standards or a clear understanding of the standards. ${ }^{110}$ As a result, any certainty believed to be provided to the owner of undeveloped land by the zoning ordinance is almost always illusory.

Any purchaser who acquires undeveloped land and calculates its fair market value solely on the basis of its existing zoning is apt to be very disappointed.111 Zoning changes producing staggering decreases in value consistently have been upheld by the courts. As

1071 R. ANDERSON, supra note $13, \$ 4.27$ (citing cases).

108 Hagman, The Vesting Issue, supra note 39, at 533.

109 Ellickson, supra note 20, at 694. Professor Ellickson states that "[n]ationally, about three-quarters of all rezoning applications are approved by governing bodies, and a slightly greater fraction of variance requests are approved by the boards of zoning appeals." Id. (footnote omitted). See also A. MANVEL, supra note 24, at 23, 31. The National Commission on Urban Problems found that in the 47 largest cities surveyed, an average of 1,030 rezoning positions were acted upon per city per year with an approval rate of $72 \%$. Id. 17 .

110 One Los Angeles study found:

[T] he term "zoning" has lost much of its significance in the City of Los Angeles, for it has come to mean promiscuous changes in the zoning pattern rather than adherence to consistent, comprehensive zoning. Procedures in actual practice have frequently become so loose that even the limited requirements of the City Charter have not been met in numerous variance cases. ...

$\cdots$

... Since [1946] there have been over 300 amendments to the text of the Code and several thousand changes in the Zoning Map, mainly as a result of individual requests and specific problems.

Crmizens' Committee on Zontng Practices and Procedures: A Program to Imoprove Planning and Zoning in Los ANgeles, First Report to the Mayor and Crty Councer, Summary Report 3, 5, 6 (1968), reprinted in B. Siegan, supra note 20, at 12; see also R. NELson, supra note 61 , at 169; B. SIEGan, supra note 20 , at 16 .

111 Neighbors also make a reliance argument wtih respect to zoning, although with greater success than the landowner. See, e.g., O'Brien v. City of St. Paul, 285 Minn. 378, 387, 173 N.W.2d 462, 467 (1969) (upholding a statute requiring neighborhood approval of a rezoning because "numberless homeowners have purchased and improved property relying on the protection of the statute"). 
early as Village of Euclid v. Ambler Realty Co., ${ }^{112}$ the SupremeCourt validated a zone classification which reduced the value of property seventy-five percent. Not facetiously, it recently has been suggested that among the "rights" that a purchaser obtains upon. acquisition of land is the "right' to have the municipality change the uses allowed in the existing classification." 113

The loss that may be suffered as a result of a change in zone classification, or the enactment of a law that overrides the classification, is compounded if the landowner has invested more than the purchase price. If a landowner makes pre-construction expenditures. for architectural drawings, engineering studies, soil tests, subdivision platting, lot filling, and road widening, he might expect courts to be wary of sanctioning a zoning change that would render these activities economically useless. Unfortunately, the landowner's expectations. are likely to be disappointed. For example, in one California case, ${ }^{114}$ after the approval of a final subdivision plat and a gradingpermit, but before the effective date of the Coastal Zone Conservation Act, the landowner spent over $\$ 2,000,000$ for the construction of streets and drains, and incurred additional liabilities. in excess of $\$ 700,000$. The California Supreme Court found that these expenditures did not provide the landowner with a vested right to complete the development. While this case may be an extreme example, it is by no means an isolated one.115

112272 U.S. 365 (1926).

113 Delaney \& Kominers, supra note 39, at 219.

114 Avco Community Developers, Inc. v. South Coast Regional Comm'n, $17 \mathrm{Cal}$. 3d 785, 553 P.2d 546, 132 Cal. Rptr. 386 (1976) (en banc), appeal dismissed, 429U.S. 1083 (1977).

115 See, e.g., Strong v. County of Santa Crux, 15 Cal. 3d 720, 543 P.2d 264, 125 Cal. Rptr. 896 (1975) (en banc) (developer prevented from completing the construction of a mobile home park when the building permit expired, notwithstanding an estoppel claim based on the county's prior practice of allowing completion pursuant to an expired permit so long as the project was diligently carried forward); Aries Dev. Co. v. California Coastal Zone Conservation Comm'n, 48 Cal. App. 3d 534, 122 Cal. Rptr. 315 (1975) (developer who had received the use permit, site plan approval, tentative tract map approval, demolition permit, grading permit, environmental impact report approval, and building permit for an apartment complex was denied the right to construct a condominium, because the court construed the developer's strident advocacy for prompt permit action to be in "bad faith," and because no actual construction of the condominium itself had begun prior to an anticondominium change in law); County Council v. District Land Corp., 274 Md. 691, 337 A.2d 712 (1975) (A building permit was issued for a 420 unit apartment complex but construction could not proceed until sewer permits had been issued from a separate sanitary commission. When the landowner obtained the sewer permits via a mandamus action, the zoning body rezoned the landowner's property to rural residential. No vested right was found, notwithstanding that the landownerhad expended in excess of one million dollars on architectural studies and design plans for the development).

This is not to suggest that all courts are antideveloper. Both Professor Williams and Professor Hagman have classified courts with respect to zoning matters. See I 
In the face of these cases, landowners have argued vigorously

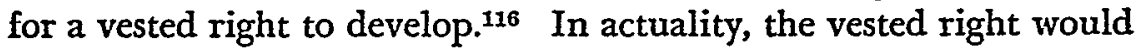
amount to an extension of the nonconforming use concept from existing uses to intended uses. To a very limited extent, courts have responded by developing a rule that a vested right may be found if the landowner has completed substantial work in good faith reliance upon a building permit. ${ }^{117}$

The very statement of the rule should illustrate that it confers little certainty on the development process. For example, there is considerable disagreement as to what amount or type of work is substantial. Some courts employ a proportionality test measuring the amount expended at the time of the zoning change against the total cost of the project.118 Other courts decide the issue on a caseby-case basis. ${ }^{119}$ Still other courts will disregard all expenditures until there is some manifest construction activity, such as excavation and foundation work. ${ }^{120}$ Because all of these formulations involve ad hoc judicial decisionmaking, the landowner is still left guessing as to whether his investment is subject to a change in public regulation.

Given the unpredictable nature of the vested rights concept, landowners have sought alternative theories for bringing certainty to the development process. The equitable analogue to the common

N. WrLLrams, supra note 2, $\S \S 6.01-.43$; Hagman, Estoppel and Vesting, supra note 39 , at 548 \& n.5. Joining California in the antideveloper or prozoning category are New Jersey, Massachusetts, Maryland, Arizona, and North Carolina. A fair number of states, including Michigan, Florida, and New York, are classified as either "erratic" or in the "good gray middle." An even larger number merely have "trends." Finally, a few states are prodeveloper, including Illinois, Rhode Island, and possibly Montana, Utah, and Puerto Rico.

116 See supra note 39 (citing articles).

117 Hagman, The Vesting Issue, supra note 39, at 522.

118 See, e.g., Gruber v. Mayor and Township Comm. of Rariton, 39 N.J. 1, 186 A.2d 489 (1962); Molino v. Mayor and Council of Glassboro, 116 N.J. Super. 195, 281 A.2d 401 (197I); Miller v. Dassler, 155 N.Y.S.2d 975 (Sup. Ct. 1956). 110 See, e.g., Nott v. Wolff, 18 Ill. $2 \mathrm{~d}$ 362, 163 N.E.2d 809 (1960); Smith v. City of Macomb, 40 Ill. App. 3d 658, 352 N.E.2d 697 (1976).

120 See, e.g., Emerald Home Builders, Inc. v. Kolton, 11 Ill. App. 3d 888, 298 N.E.2d 275 (1973) (vested right following site excavation and placement of footings); Glenel Realty Corp. v. Worthington, 4 A.D.2d 702, 164 N.Y.S.2d 635, appeal dismissed, 3 N.Y.2d 924, 145 N.E.2d 880, 167 N.Y.S.2d 939 (1957) (placement of concrete foundation affords vested right against adverse zoning ordinance).

What constitutes manifest construction activity will often be difficult for a developer to determine. The developer's quandary is obvious. He has been told often enough that he has no vested right to a permit, and hence, he reduces his construction activity until all permits are secured. Ironically, reducing the amount of construction activity directly reduces the developer's chances of claiming a vested right. Moreover, requiring manifest construction activity ignores the reality that modern development requires substantial expenditures for planning and design well in advance of the foundation work. 
law vested right is estoppel. ${ }^{121}$ While courts are usually reluctant to apply estoppel principles to the government, ${ }^{122}$ there is a growing body of case law in which the government has been estopped in zoning matters. ${ }^{123}$

The estoppel theory, however, cannot be said to provide any more certainty than the vested right theory. Indeed, estoppel may provide even less certainty because courts frequently balance the harm to the landowner if estoppel is not invoked against the effect invoking estoppel would have on zoning policy. ${ }^{124}$ Thus, it has been asserted that the traditional elements of estoppel are merely a "threshold inquiry," with the decisive factor being a judicial assessment of the importance of the public policy involved..$^{125}$

The introduction of balancing to the estoppel theory not only increases uncertainty under the existing system, but also allows the judiciary to intrude into the substance of land use regulation. It has been suggested, for example, that a rezoning which has been "carefully studied" should tip the balance in favor of the government. ${ }^{126}$ How does a court determine whether a matter has been

121 The traditional elements of equitable estoppel are:

a. The party to be estopped must be apprised of the facts;

b. He must intend that his conduct shall be acted upon, or must so act that the party asserting the estoppel had a right to believe it was so intended;

c. The other party must be ignorant of the true state of facts; and

d. He must rely upon the conduct to his injury.

Practisnge Law Institute, Modern Controc of Land Deveropment 260 (1980). 122 D. MaNDEXKER \& R. Cunningham, supra note 22, at 680. For a discussion of the concept of zoning estoppel, see Heeter, Zoning Estoppel: Application of the Principles of Equitable Estoppel and Vested Rights to Zoning Disputes, 4 UnB. L. ANN. 63 (1971).

123 See City of Long Beach v. Mansell, 3 Cal. 3d 462, 476 P.2d 423, 91 Cal. Rptr. 23 (1970) (en banc) (finding a pattern of development as well as local and state approvals sufficient to invoke estoppel).

124 The California Supreme Court in Mansell stated:

After a thorough review of the many California decisions in this area, as well as a consideration of various out-of-state decisions, "we have concluded that the proper rule governing equitable estoppel against the government is the following: The government may be bound by an equitable estoppel in the same manner as a private party when the elements requisite to such an estoppel against a private party are present and, in the considered view of a court of equity, the injustice which would result from a failure to uphold an estoppel is of sufficient dimension to justify any effect upon public interest or policy which would result from the raising of an estoppel.

Id. at 496-97, 476 P.2d at $448,91 \mathrm{Cal}$. Rptr. at 48.

125 Holliman, Development Agreements and Vested Rights in California, 13 URB. LAw. 44, 60 (1981).

126 Heeter, supra note 122 , at $94-95$. 
carefully studied? The number of hours the zoning people ruminated over the matter? Whether the change reflects the master plan? Whether the change reflects the court's conception of good zoning policy? Admittedly, courts in equity matters engage in the weighing of public and private interest, and in an extraordinary case, this type of judicial behavior may be singularly appropriate. But cases of uncertainty in the land development process are not extraordinary. Often landowners expend funds for planning, engineering, street, and utility work only to face a change in zoning regulation that prevents the completion of the project. A more certain and consistent method of resolving these land use disputes, without the delay of a judicial balancing of the equities in each case, is necessary. The current handling of these matters is clearly unsatisfactory. The landowner runs the risk of wrongly predicting the outcome of complex litigation; the zoning body runs the risk of having its latest policy deemed unimportant or ill-conceived by the judiciary, and the community loses the benefits that otherwise would have accrued had private and public expenditures been directed at productive, rather than adaptive, behavior.

Dissatisfaction with the level of certainty provided by the judiciary has led to the enactment of various statutory vesting provisions which afford some protection to the landowner from a change in land use regulation. ${ }^{127}$ For example, savings clauses occasionally have been included in local ordinance amendments expressly providing for the completion of any building or use for which a permit has been lawfully granted prior to the effective date of the amendment. ${ }^{128}$ These clauses frequently track the language of judiciallycreated vesting or estoppel theories, but leave out vague requirements calling for substantial work or good faith reliance. ${ }^{129}$

127 For a detailed analysis of such clauses and their purposes and effects, see Annot., 49 A.L.R.3d 1150 (1973).

128 See, e.g., Rockshire Civic Ass'n, Inc. v. Mayor and Council of Rockville, 32 Md. App. 22, 358 A.2d 570 (1976), in which the court upheld a developer's right to six acres of commercial zoning within a 286-acre planned unit development, notwithstanding a change in the zoning regulations limiting commercial development in planned zones to five acres. The zoning regulation change contained a saving clause which provided that previously approved applications should continue in full force and effect. Id. 579 .

129 See Cunningham \& Kremer, Vested Rights, Estoppel, and the Land Development Process, 28 Hastings L.J. 625, 626 (1978); Hagman, Estoppel and Vesting, supra note 39 , at 575 .

Cunningham and Kremer's proposed vesting rule is as follows:

The rule of irrevocable commitment protects from new laws any project to which the developer has made a reasonable and irrevocable commitment of resources. The scope of the protection granted, however, 
Statutory vesting provisions also may provide protection for the developer earlier in the development process. ${ }^{130}$

Perhaps the most common statutory vesting provision under the existing system is found not in zoning, but in subdivision regulation. Subdivision regulation is growing in importance, especially with regard to undeveloped land. It is not uncommon for statutes and ordinances to provide that once a preliminary plat is approved, land use officials are precluded from disapproving the final plat if it is timely submitted and meets the conditions appended to the preliminary plat.131 Unfortunately, this seemingly broad protection has been undermined by narrow judicial interpretation. ${ }^{132}$

is determined by a detailed analysis of the resource commitments, the

planned objectives of the project, and the concerns of the general welfare. Cunningham \& Kremer, supra, at 715. Under this test, not all development contemplated is necessarily vested. For example, Cunningham and Kremer suggest that the government permit involved be evaluated on the basis of how much of the development project detail was approved by the government. If the government approved the specifics of the project, they are bound by it, so long as such a vested right is "necessary to recover the investment represented by the reasonable irrevocable commitments of resources." Id. 726. This rule is also tempered by a balancing of the general welfare against the interest of the developer.

Professor Hagman's similar, and earlier, proposal also adopts a balancing approach. Specifically, Hagman would provide a developer with a vested right if the court finds "( 1 ) substantial construction pursuant to any permit; (2) which construction would either be wasted, or would not have been undertaken if completion of the project was known to be precluded; and (3) if compliance with any changed law is not required in order to protect fundamental public health or safety." Hagman, The Vesting Issue, supra note 39, at 558. Importantly, Professor Hagman's rule recognizes that the modern land use process is dependent upon multiple permits, and not a single building permit. In addition, the rule implicitly requires the jurisdiction to justify the change of law with respect to issues of fundamental public health or safety, rather than merely relying upon "whimsy." Finally, while Professor Hagman's proposed rule may be characterized as "prodeveloper," it is directed more at avoiding the senseless waste of economic resources that results from the arbitrary change of land use regulations than at favoring one party over another. For an interesting comparison of the Cunningham and Kremer proposal with the Hagman proposal, see Hagman, Estoppel and Vesting, supra note 39 , at $582-84$.

130 See, e.g., CAL. Pư. Res. Code $\$ \$ 25000-25903$ (West 1977). This statute created a State Energy Resources Conservation and Development Commission, and gave the commission control to preempt all state and local agencies with respect to electric transmission lines and thermal power plants. Id. $\S 25500$. Power plant developers with construction plans "to commence within three years from the effective date" of the Act do not have to comply with the new law. Id. $\$ 25501$. This is a much more liberal vested rights provision than the traditional vested rights rule which would have required compliance with the new law absent substantial construction pursuant to a building permit.

131 See, e.g., CAL. Gov'r CoDE $\$ 66474.1$ (West Supp. 1980) (requiring the approval of a final map if submitted in substantial compliance with an approved tentative map); N.J. STAT. ANN. $\$ 40: 55 D-49$ (West Supp. 1981) (providing that tentative plat approval shall confer upon the applicant assurance for a three year period that the "general terms and conditions" upon which tentative approval was granted will not be changed).

132 See Save El Toro Ass'n v. Days, 74 Cal. App. 3d 64, 141 Cal. Rptr. 282 (1977) (approval of a final map found to be a discretionary act under local law). 
More detrimental to the certainty provided by statutory vesting provisions in subdivision cases is that the statutes themselves may provide no assurance that other applicable land use regulations will not render the subdivision approval valueless. For instance, if a subdivision is approved with one-half acre lots, such approval may not prevent zoning officials from rezoning the parcel to two-acre lots. ${ }^{133}$

While statutory vesting mechanisms hold the promise of greater certainty, they have remained either unenacted, infrequently used, or frequently overridden by an existing land use allocation system that has been unsympathetic, if not oblivious, to the waste of economic resources. ${ }^{134}$

But see Youngblood v. Board of Supervisors, 22 Cal. 3d 644, 586 P.2d 556, 150 Cal. Rptr. 242 (1978) (public interest found to require a local government to exercise its discretion regarding approval of a proposed subdivision when acting on the tentative map). Thus, while California requires that subdivision maps be consistent with general plans, if the general plans change after approval of a tentative map, the subdivider is nevertheless entitled to final map approval. Of course, the local governing body may still undo the protection given the developer by changing other applicable land use regulation. See infra note 133. A court may also strictly interpret the protection afforded the developer by the subdivision control. See Levin v. Township of Livingston, 35 N.J. 500, 173 A.2d 391 (1961), in which the court construed a New Jersey statute that protected a developer from change in the general terms and conditions of tentative approval to mean that a municipality was nevertheless free to change the specifications for street pavement. The Levin case appears to have been overruled by a subsequent change in New Jersey statute. See N.J. STAT. ANN. $\$ 40: 55 D-49$ (a) (West Supp. 1981) (defining "general terms and conditions" to include the "layout and design standards for streets, curbs and sidewalks").

133 This is the fate that befell the developer in the case of Youngblood v. Board of Supervisors, 22 Cal. 3d 644, 586 P.2d 556, 150 Cal. Rptr. 242 (1978). Thus, although Youngblood held that the developer had a vested right in final subdivision approval for one acre lots, the zoning change to two acre minimums meant that "one will have to buy two adjacent lots to build a house in the subdivision." Hagman, The Metamorphosis of Justices Mosk and Tobriner and the California Supreme Court, LAND UsE L. \& ZonIng Dig., March 1979, at $10,11$.

134 Professor Hagman's proposal was submitted to the California legislature for consideration, but it became the bridesmaid to a rival suitor in the form of a development agreement statute. This statute facially provides more certainty to developers who successfully enter into agreements with cities and counties that immunize a development project from any change in general or specific plans, zoning, subdivision, or building regulation. Compare Cal. Ass. Bill No. 3545, 1977-78 Sess., reprinted in Hagman, Estoppel and Vesting, supra note 39, at 592-96 (Hagman's proposal) with CAL. Gov'T CoDE \$\$65864-65869.5 (West Supp. 1980) (the enacted development agreement statute).

The certainty provided by the development agreement statute, however, may be illusory. First, it is not entirely clear that a local government can contract away its authority to regulate in the future. See infra text accompanying notes 267-303. Second, the statute only provides for certainty with respect to rules and regulations promulgated by cities and counties. Thus, the agreement may be partially defeated by an inconsistent rule or regulation promulgated by a specialized government agency, such as the California Coastal Zone Commission. Not being a sore loser, Professor Hagman has thoughtfully analyzed the development 


\section{An Alternative Free Enterprise Development System}

A land use allocation system that is unfair, inefficient, inflexible, and uncertain has little to recommend it. What immediately follows is an outline of an alternative land use allocation system for undeveloped land that attempts to remedy the multiple shortcomings of the existing system. The alternative system reduces public control through the repeal of existing zoning and subdivision enabling legislation as applied to undeveloped land. New enabling legislation would be drafted to authorize limited public control, principally in the areas of development intensity and public improvements, while at the same time maximizing individual freedom and private decisionmaking in the land development process. After outlining the alternative system, the discussion will focus upon the primary elements of the alternative system and the legal and policy issues raised by its implementation.

\section{A. An Outline of the Alternative System}

\section{Defining Land Use Intensity}

First, all undeveloped land would be reclassified agricultural open space. ${ }^{135}$ Second, local legislative bodies and their planning staffs or consultants, together with interested citizens, would then define the land use intensity (LUI) policy ${ }^{136}$ for a specified period of time ${ }^{137}$ for the undeveloped land within the entire community.

agreement statute. See Hagman, Development Agreements, 3 ZoNING \& PLAN. L. REP. 65,73 (1980).

135 Given the initial urban orientation of zoning, there was some uncertainty as to the ability to zone agricultural or undeveloped land. See Reps, The Zoning of Undeveloped Areas, 3 Syracuse L. REv. 292 (1952); Warp, The Legal Status of Rural Zoning, 36 IrL. L. Rev. 153 (1941); Comment, Colorado Cases on Zoning-Validity of Zoning Undeveloped Areas, 29 RockY MTN. L. REv. 202 (1957). For the most part, doubts about the applicability of zoning to rural areas have been removed, see, e.g., Zahn v. Board of Pub. Works, $195 \mathrm{Cal}$. 497, 234 P. 388 (1925), aff'd, 274 U.S. 325 (1927), and there never was any real question that the SZEA was intended to extend to both developed and undeveloped land, SZEA, supra note 25 , at $\$ 1$.

138 See infra text accompanying notes $232-49$.

137 Comprehensive amendment of zoning ordinances under the existing system is rare. The ordinances are not so amended because of the practical and political difficulty inherent in redefining the exact uses permitted for each particular parcel within a sizable community. Because the alternative system avoids the pre-set nature of the existing system, and any specific policy application, it should be easier to revise the LUI schedule on a more frequent basis. Revision of LUI schedules on a fairly frequent basis would coincide well with the planning profession's notions of "strategic incrementalism." See supra note 88. Of course, revisions should not be made so frequently that they undermine the certainty provided by the system itself. Thus, it may be wise for a community to establish a. 
Third, the LUI would be expressed in four separate schedules for residential, commercial, industrial, and mixed-use projects. Each schedule would disclose the maximum density permitted for each type of development. To preserve absolute procedural fairness, however, the legislative body would not specify which land could be developed at any given intensity. Moreover, to prevent the legislature from misusing the LUI schedules in the same manner as the holding zones under the existing system, the legislative body would not be enabled to allocate any specified portion of the community's undeveloped land to a particular use schedule. Thus, the legislative body can indirectly control the growth of the community by setting appropriate limits on project density and by periodically revising those limits, but not directly through the predetermined allocation of land into specific use categories.

\section{Selecting LUI Ratings for Specific Parcels}

Prior to development, any landowner would be able to select the intensity desired, up to but not exceeding the maximum allowed under any of the use schedules, by filing written notice with an administrative body, the Land Use Control Agency (LUCA). Once made, an LUI rating selection would be valid for 180 days, after which time it would lapse, unless the landowner entered into a Public Improvement Contract with LUCA within that period. If the LUI rating selection lapses, the landowner, or anyone else having an interest in the property for which the lapsed LUI rating was selected, would be disqualified from seeking the same LUI rating for the same property for one year. It should be noted that after the selection and the successful negotiation of a Public Improvement Contract, ${ }^{138}$ the LUI rating could not be changed or altered uni-

minimum period of time during which an LUI schedule will be effective, such as one year.

In devising the LUI schedules, it is most important that the local legislative body have at its command every piece of information concerning the community that it can assemble. With this information, the members of the legislative body will be able to make projections as to the future development of the community. If the projections meet with legislative and public approval, existing LUI schedules can be continued. If the projections prove to be unsatisfactory, however, the legislative body, with citizen and planner advice, can revise LUI schedules in a manner that it believes will produce a more satisfactory result. Thus, initial definition and revision of LUI schedules resembles, to a certain extent, Professor Hagman's conception of what planning can legitimately hope to be. In this regard, Professor Hagman's suggestion that planning engage in projections of no longer than 20 months should be bome in mind when the period for revising LUI schedules under the alternative system is determined. See D. HAGMaN, supre note 19, at 209-12.

138 See infra text accompanying notes 262-65. 
laterally by either LUCA or the landowner; the LUI could only be changed or altered by mutual agreement pursuant to an Intensity Modification Contract, ${ }^{139}$ privately negotiated by and between LUCA and the landowner.

Just as the selection of the LUI rating would be determined solely by the landowner, the use of a specific parcel of land, or the development of private improvements, would be essentially a private decision. The landowner would be free to develop his land for any residential, commercial, or industrial use, or any combination thereof, permitted by the selected LUI range. Neither LUGA nor any other local ${ }^{140}$ legislative or administrative body could dictate permitted use, structural height, or design. These matters of private improvement would be determined solely by the landowner in response to market demand. Of course, the landowner would remain subject to the common law of nuisance and certain other public laws, such as building, health, and sanitation codes, which would be administered by LUGA in order to promote a unified land use policy.

139 See infra text accompanying notes 266-67.

140 Regional, state, interstate, and federal land use control is largely a product of the environmental decade and what has come to be known as the "quiet revolution" in land use controls. See F. Bosserman \& D. Callines, The Qunet RevoLUTION IN LAND USE CONTROL (1972). The underlying notion for this type of land use control is that local entities are too parochial to consider the impact of large dimensional projects, certain types of specialized development (such as shopping centers, airports, and hospitals), and what have become known as areas of "critical state concern," such as areas of particular scenic value. Frequently, the advent of state involvement in land use matters has meant the development of a "double-veto system"; that is, a system requiring that a developer obtain permits not only from the local community, but also from a state or regional commission. For an opinion favorable to the increase in state, regional, and federal involvement in land use matters, see R. HEALY, LAND USE AND THE STATES 6-13 (1976).

While a detailed examination of regional, state, and federal land use controls is beyond the scope of this Article, the alternative system disfavors such controls. The underlying premise of the alternative system is that land use decisions generally should be made individually in the marketplace and only minimally controlled in those cases where the market has not demonstrated an ability to produce an optimal decision-for example, with respect to density and public improvement. Only minimal public control should exist on a local level in order to avoid the unnecessary lengthening of the development process and the elimination of diversity which generally results from state and federal involvement in land use matters. This is not to suggest that the state or federal government may not have a legitimate interest in protecting specific areas, such as wetlands, shorelines, and floodplains; it does suggest, however, that such protection should be accomplished, not by positive regulation, but by the outright public purchase of property interests (whether of a fee, scenic easement, or development rights nature), subsidization, or direct public development. It is an incidental advantage of the alternative system that the cost of such purchases would be within the realm of possible government expenditure, because all speculative use value is conceded to belong to the public in the first place. See infra note 142 and accompanying text. Purchases of land in fee simple for environmental purposes would thus be made at the open space valuation. 


\section{Public Improvements}

While the alternative system acknowledges that private improvement decisions are best made privately, it also xecognizes that public improvement decisions are best handled püblicly. In this regard, LUCA is given complete authority over the location, quantity, and quality of public improvements such as streets, sewers, parks, and schools. In most cases, the landowner will propose a public improvement plan, but in all cases LUCA's decision on these matters will prevail. The final decision will be embodied in the Public Improvement Contract.

Under existing law, it is decidedly unclear what public control bodies can require of a landowner in the way of infrastructure and on-site and off-site public improvements. ${ }^{141}$ The alternative system eliminates this lack of clarity with a clear rule: as a condition of development at the selected LUI rating, the landowner shall undertake all on-site and off-site public improvements required by LUCA so long as the cost of these improvements do not exceed an agreed amount.

What amount will the landowner and LUCA treat as the public improvement "agreed amount"? Under the alternative system, the "agreed amount for public improvement" shall be equal to the difference between the fair market value of the property at the landowner-selected LUI rating and the fair market value of the property in its agricultural/open space use-that is, fair market value after LUI selection minus fair market value before. It is no accident that the agreed amount equals what Henry George defined as the unearned increment of land value-the value a given parcel of land has because of adjacent beneficial improvements not attributable to the landowner, be they private or public in origin. ${ }^{142}$

The direct relationship between the unearned increment available for public improvement and other community purposes and the selected LUI rating should ensure that LUI ratings are rationally established by the local legislative body. The existing system is often permeated by a "no growth" attitude, largely because de-

141 See infra text accompanying notes 306-17.

142 H. George, Progress and Poverty 358-67 (1962). Essentially, George advocated the recoupment of economic rents associated with unimproved landthat is, the amount in excess of the amount necessary to induce a factor's participation in the production process. Thus, because virtually everything paid to the owner of unimproved land, except perhaps the cost of negotiating and signing a lease, is unnecessary to keep the owner invested, increasing a land value tax (which decreases land value) will not induce the owner to withdraw his land from a competitive market. 
velopment is viewed as imposing economic costs on the community and economic benefits on the private landowner. Thus, the existing system provides little incentive to the community to permit any development. In contrast, the alternative system offers the community the economic value of the unearned increment for public improvement or general revenue, but the community must establish a rational set of possible LUI ratings (and hence a reasonable level of development) in order to obtain it.

\section{Changing Regulation by Contract}

While the alternative system has incentives that favor reasonable levels of development, there may be occasions when either the landowner or LUCA will wish to depart from the selected LUI rating for a specific property. Under the existing system, such departures would be treated as zone amendments, variances, or special exceptions; however, because of the abuses and inadequacies associated with these mechanisms, they would be abandoned under the alternative system.

Under the alternative system, if the landowner and LUCA want to alter the LUI rating selected for a given parcel, they must bargain with each other for such a change. For example, if the landowner desires to develop at a higher intensity than the one actually chosen or available on the LUI schedule, the landowner may offer LUCA greater control over various aspects of the private improvements in exchange for the increase in intensity. Similarly, if LUCA desires to assert greater public control over the private improvements, it may offer the landowner a return of part of the unearned increment or the prospect of less public improvement. In either case, neither LUCA nor the landowner is bound to the change unless an Intensity Modification Contract is entered into and placed of record. Such contracts would be as enforceable as any other private agreement, subject only to "reasonable and necessary" impairment to accommodate the police power..$^{143}$

\section{B. An Examination of the Primary Elements of the Alternative System}

Having outlined the whole of the alternative system, what follows is a closer look at some of its parts. In particular, the proposal to reclassify all undeveloped land to agricultural/open space will be evaluated in light of recent Supreme Court decisions dealing with 
land use regulation and the constitutional requirement that property not be taken for public use without the payment of just compensation.144 Second, the role of the neighbor under the existing system will be explored. ${ }^{145}$ Suggestions will be made for redirecting neighbor participation toward policymaking, rather than policy application. Possible constitutional objections to such redirection are evaluated. Third, the scope of public land use control is narrowed to issues of land use intensity. ${ }^{146}$ Fourth, the treatment of, and objections to, contractual land use agreements under both the existing and alternative systems are examined.147 Recent Supreme Court and state court decisions dealing with the contract clause and the reserved power doctrine are construed to permit the Public Improvement and Intensity Modification Contracts envisioned under the alternative system. Finally, methods of financing public improvements under the existing system are examined in relation to the alternative system's proposal to recapture the unearned increment and apply it to the cost of public improvement. ${ }^{148}$ The similarities and differences to previous land value taxation theories are also discussed.

\section{Reclassification of Undeveloped Land to Agricultural/Open Space}

No land use controversy has been more unresolvable than the "taking issue." 149 The fifth amendment commands that "private property [shall not] be taken for public use, without just compensation" 160 but recitation of this fundamental constitutional principle merely begs the question of when, in fact, property is taken. Numerous scholarly attempts to "draw the line" between takings and police power regulations have been made, ${ }^{151}$ and little will be said here as to their individual success or failure. It is worth observing, however, that the scholarly preoccupation with the taking

144 See infra text accompanying notes 149-73.

145 See infra text accompanying notes 174-231.

146 See infra text accompanying notes 232-49.

147 See infra text accompanying notes $250-303$.

148 See infra text accompanying notes 304-47.

149 See, e.g., B. Ackerman, supta note 40; F. Bossetiman, D. Calties \& J. Banta, supra note 41; Berger, supra note 41; Dunham, $A$ Legal and Economic Basis for City Planning, 58 CoLUM. L. Rev. 650 (1958); Michelman, supra note 40; Sax, Takings, Private Property, supra note 40; Sax, Takings and the Police Power, supra note 40.

160 U.S. Const. amend. V.

151 See supra note 149. 
issue may have diverted needed attention from the deficiencies in the existing land use allocation system.

Judicial challenges to land use regulation based on the just compensation clause have had little success. Although the Court, speaking through Justice Holmes, warned in Pennsylvania Coal Co. v. Mahon ${ }^{152}$ that " $[\mathrm{t}]$ he general rule at least is, that while property may be regulated to a certain extent, if regulation goes too far it will be recognized as a taking," 153 the compensatory limit on land use regulation has been diluted to the point where the Constitution provides little, if any, protection to the landowner. Indeed, the Supreme Court of California has held that even a regulation which destroys "substantially all reasonable use" of a property cannot constitute a compensable taking, but at most will be invalidated as an improper exercise of the police power. ${ }^{154}$

152260 U.S. 393 (1922).

153 Id. 415.

154 Agins v. City of Tiburon, 24 Cal. 3d 266, 598 P.2d 25, 157 Cal. Rptr. 372 (1979) (en banc), aff'd, 447 U.S. 255 (1980).

Whether compensation must be paid for a taking recently was argued before the U.S. Supreme Court in San Diego Gas \& Elec. Co. v. City of San Diego, 101 S. Ct. 1287 (1981). In San Diego Gas, the city rezoned some of the plaintiff's industrial property to agricultural use, while also establishing an open-space plan that included much of the property. The plaintiff alleged a taking and sought damages, as well as mandamus and declaratory relief. A trial resulted in a damage award in excess of $\$ 3$ million; ultimately, however, the California Court of Appeal reversed in light of the California Supreme Court's decision in Agins. Speaking for the U.S. Supreme Court after certiorari had been granted, Justice Blackmun held that the California state court decision, which equivocated on the issue whether any taking had in fact occurred, was not reviewable because of the absence of a "final judgment" pursuant to the requirements of 28 U.S.C. $\$ 1257$ (1976). There also was some dispute over what the California courts had decided in Agins, and refusing to reach the merits allowed the Court a prudential way of deferring decision on the issue. In dissent, Justice Brennan argued that the lower court's decision was a final judgment within the meaning of the jurisdictional statute and thus expressed an opinion on the merits of the taking issue. Specifically, he believed that "[p]olice power regulations such as zoning ordinances and other land-use restrictions. can destroy the use and enjoyment of property" and thus may qualify as a taking within the meaning of the just compensation clause of the fifth amendment. 101 S. Ct. at 1304. He cited with approval language from Agins v. City of Tiburon, 447 U.S. 255, 260 (1980), suggesting that " $[t]$ he application of a general zoning law to particular property effects a taking if the ordinance does not substantially advance legitimate state interests ... or [if it] denies an owner economically viable use of his land." $101 \mathrm{~S}$. C. at 1301. Once it is established that a taking has occurred, "the Constitution demands that the government entity pay just compensation for the period commencing on the date the regulation first effected the 'taking,' and ending on the date the government entity chooses to rescind or otherwise amend the regulation." Id. 1304 (footnotes omitted). As to the chilling effect that requiring payment of compensation may have on the freedom of land use officials, Justice Brennan simply noted that "the applicability of express constitutional guarantees is not a matter to be determined on the basis of policy judgments ....." Id. 1308. Because Justices Stewart, Marshall, and Powell joined in the dissent, id. 1296, and Justice Rehnquist's concurrence in the judgment of the Court noted that he "would have little difficulty in agreeing with much of" the dissenting 
Nonetheless, a proposal to classify all undeveloped land to agricultural/open space under the alternative system warrants some examination of the minimum standard necessary to avoid a findingthat a taking has occurred. Moreover, the examination serves to. highlight the property interests left unprotected by the just compensation clause, and why these interests are protected under the alternative system.

The Supreme Court presented a comprehensive restatement of the taking issue in Penn Central Transportation Co. v. New York City. ${ }^{155}$ At issue was the denial by the New York City Landmarks Preservation Commission of approval for a fifty-three story building to be constructed above Grand Central Station. The station, pursuant to a city act, had been designated a historic landmark, imposing on the owner (Penn Central) certain maintenance duties, and requiring Commission approval for any modification of the existing structure. A designated landmark was subject to these restrictions in addition to all existing zoning regulations. Following denial of two office building proposals, Penn Central brought suit in state court, claiming that its property had been taken without just compensation. The Supreme Court affirmed the New York Court of Appeals in deciding that there had been no taking.

The Court's analysis indicates that if an owner is left with an "economically viable" use, there is no compensable taking. ${ }^{158}$ The Court noted that "the 'taking' issue in [land use regulation] contexts is resolved by focusing on the uses the regulations permit" 157 rather than on the diminution in value related to uses precluded. Penn Central failed to establish that there had been a taking because its present use of Grand Central Station was not abridged. In the words of the Court, "the law does not interfere with what must be regarded as Penn Central's primary expectation concerning the use of the parcel." 158

Although not stated expressly, the Court made it clear that an investment based on speculative uses alone would not provide the

opinion, $i d .1294$, it is quite likely that a majority of the Court agrees with Justice Brennan's interpretation of the taking issue. Indeed, the Court's opinion itself noted that "the federal constitutional aspects of that issue are not to be cast aside lightly. ..." Id. 1294. Thus, preliminary indications are that limiting a landowner's taking remedy to invalidation may ultimately be found unconstitutional. See Kmiec, Regulatory Takings: The Supreme Court Runs Out of Gas in San Diego, 57 IND. L.J. - (forthcoming 1982).

155438 U.S. 104 (1978).

156 Id. 138 n.36; see Agins v. City of Tiburon, 447 U.S. 255, 260 (1980).

157438 U.S. at 131.

158 Id. 136. 
baseline for determining a loss of "economic viability" unless the existing use itself is destroyed. The Court noted, and Penn Central conceded, that prior decisions "uniformly reject the proposition that diminution in property value, standing alone, can establish a 'taking.'" 159 The Court cited cases supporting the proposition that value attributable to development rights is held subject to the police power, and loss of an investment reflecting that value does not constitute a taking. ${ }^{160}$ Thus, in most cases, the just compensation clause protects expectations based on the existing use of the land, or what the Court termed "distinct investment-backed expectations." 161 A number of cases cited with approval by the Court, however, reduce that protection still further. ${ }^{162}$ For example, in Goldblatt $v$. Hempstead, the plaintiff owned a gravel quarry whose existing use was destroyed by regulation, yet no taking was found.163 Thus, it would seem that even when an existing use is destroyed, if some theoretically possible use remains to the plaintiff allowing a return comparable to the return of the destroyed existing use, the land remains "economically viable" and there is no taking.

Because the reclassification to agricultural/open space under the alternative system applies only to undeveloped land, the only possible value loss is speculative value. Under Penn Central, the loss of this value is clearly not a taking. Further, because under the alternative system speculative value is subject to recapture by LUCA at the point of development, ${ }^{164}$ that value is conceded in advance to belong to the community, and hence cannot be "taken." From the point of view of the landowner who wishes to use his land as farmland, the recapture provisions, coupled with requirements that the property's taxation be based upon its existing use, ${ }^{165}$ relieve some of the pressure to sell for development and suggest that farming will remain an economically viable use so long as market demand dictates.

Although not constitutionally mandated, the alternative system permits the development of contemplated uses of undeveloped land in addition to the economically viable agricultural/open space classification. A number of reasons favor affording more development opportunities for the landowner than are constitutionally required.

159 Id. 131.

160 Id. 125.

101 Id. 124.

162 Id. 125-27.

163369 U.S. 590 ( 1962 ).

104 See infra notes 304-47 and accompanying text.

165 See infra notes 341-44 and accompanying text. 


\section{a. Removal of Hidden Growth Impediments}

The alternative system accommodates contemplated uses to ensure that the regulatory process itself is not used as an impediment to rational development, as it often is under the existing system. This does not mean that a community cannot decide to slow its growth. It does mean that any such policy must be either explicitly reflected in the LUI schedule or bargained for under an Intensity Modification Contract, both of which are radical departures from the existing system. Under the existing system, a no-growth attitude is often hidden in numerous and expensive requirements, such as minimum lot and dwelling sizes. ${ }^{166}$ Similarily, a landowner is seldom compensated under the existing system for the decrease in land value associated with growth regulation, whereas the possibility of compensation exists for a landowner if it is successfully negotiated for under an Intensity Modification Contract. ${ }^{167}$

166 See Aloi, Goldberg \& White, Racial and Economic Segregation by Zoning: Death Knell for Home Rule? 1 U. Tox. L. Rev. 65, 74-80 (1969); Bigham \& Bostick, Exclusionary Zoning Practices: An Examination of the Current Controversy, 25 Vand. L. Rev. 1111 (1972); Sager, Tight Little Islands: Exclusionary Zoning, Equal Protection, and the Indigent, 21 STAN. L. Rev. 767 (1968). Compare Simon v. Town of Needham, 311 Mass. 560, 42 N.E.2d 516 (1942) (upholding one acre zoning) with National Land \& Inv. Co. v. Kohn, 419 Pa. 504, 215 A.2d 597 (1965) (invalidating four acre zoning). Justice Roberts in National Land explicitly recognized the relationship between minimum lot size and a no-growth attitude:

Four acre zoning represents Easttown's position that it does not desire to accommodate those who are pressing for admittance to the township unless such admittance will not create any additional burdens upon governmental functions and services. The question posed is whether the township can stand in the way of the natural forces which send our growing population into hitherto undeveloped areas in search of a comfortable place to live. We have concluded not. A zoning ordinance whose primary purpose is to prevent the entrance of newcomers in order to avoid future burdens, economic and otherwise, upon the administration of public services and facilities can not be held valid.

Id. at $532,215 \mathrm{~A} .2 \mathrm{~d}$ at 612 .

For decisions upholding minimum dwelling size requirements, see, for example, De Mars v. Zoning Comm'n, 142 Conn. 580, 115 A.2d 653 (1955); Lionshead Lake, Inc. v. Township of Wayne, 10 N.J. 165, 89 A.2d 693 (1952), appeal dismissed, 344 U.S. 919 (1953). For comments on the Lionshead Lake decision, see Haar, Zoning for Minimum Standards: The Wayne Township Case, 66 Hanv. L. Rev. 1051 (1952); Nolan \& Horack, How Small a House?-Zoning for Minimum Space Requirements, 67 HARv. L. REv. 967 (1953); Haar, Wayne Township: Zoning for Whom?-In Brief Reply, 67 Harv. L. Rev. 986 (1953); Williams \& Wacks, Segregation of Residential Areas Along Economic Lines: Lionshead Lake Revisited, 1969 Wrs. L. Rev. 827.

Professor Williams has noted that "[i]n some counties in northern New Jersey, of the vacant land which is zoned for residence and readily developable for that purpose, about 75 percent is zoned to require houses of not less than 1,200 square feet, and substantial areas are zoned for houses of at least 1,600 square feet." Williams, The Three Systems of Land Use Control, 25 Rutgens L. REv. 80, 93 (1970) (footnote omitted); see also $2 \mathrm{~N}$. Wrrrssss, supra note $2, \S 63.12$.

167 See supra text accompanying note 143. 


\section{b. Increasing Individual Freedom}

The accommodation of contemplated uses also increases the role of private decisionmaking in the land use process. While the application of the Penn Central standard mandates only minimum economic viability, land is frequently economically viable in a range of uses, some more highly demanded than others. The alternative system assumes that public policy should extend sufficient freedom to the landowner to respond to the market with a use that the owner believes would be the most economically viable and personally satisfying.

\section{c. Historical Equity}

Finally, the alternative system allows for the development of contemplated uses in order to uphold, at least partially, subjective investment expectations of individuals who purchased undeveloped land prior to the enactment of the alternative system. Upholding these subjective expectations seems especially appropriate in view of the confusion surrounding the taking issue before, and even after, the Court's decision in Penn Central. ${ }^{168}$

\section{d. Additional Benefits of Reclassification}

Reclassifying all undeveloped land as agricultural/open space also may prevent the premature conversion of viable agricultural

168 To some extent, this confusion was reflected by the Court itself in San Diego Gas \& Elec. Co. v. City of San Diego, 101 S. Ct. 1287 (1981). See supra note 154 .

Implicitly, by leaving the terms "reasonable investment expectations" and "economic viability" undefined, the Court's opinion leaves landowners uncertain as to the extent of their property rights. Moreover, the treatment of these concepts in Penn Central is confusing and somewhat at odds with traditional due process analysis. Specifically, because the Court characterized the landmark preservation ordinance in Penn Central as an exercise of the police, rather than the eminent domain, power, it is not entirely clear why the Court required not only that the landmark ordinance meet the traditional rationality test, but also that it satisfy notions of reasonable beneficial use such as investment expectations and economic viability. Previous Court decisions had suggested that a consideration of the reasonable beneficial use remaining after regulation was relevant only to the threshold categorization of the governmental regulation as either based on the eminent domain or police power. See Goldblatt v. Town of Hempstead, 369 U.S. 590 (1962). Penn Central, however, uses the reasonable beneficial use or economic viability concept as an independent criterion under the police power analysis. Whether this signals an attempt by the Court to engage in more rigorous substantive economic due process analysis, or oppositely, a retreat from constitutional protections of property interests by placing a consideration of the "nature and extent of the interference" with property interests at a point at which it will seldom benefit landowners, is open to question. For a good discussion of Penn Central's ambiguity, see Blumstein, A Prolegomenon to Growth Management and Exclusionary Zoning Issues, 43 Law \& Contemp. Probs. 5, 87-91 \& n.606 (Spring 1979). 
land to homesites. As urban areas expand, adjacent farmland often dramatically increases in value, a fact that does not go unnoticed by local property tax assessors. The corresponding dramatic increase in the property tax, together with the lure of a windfall profit, may result in the development of farmland earlier than may be justified by market demand.

Numerous schemes have been proposed to reduce the value and property tax pressure faced by farm owners. ${ }^{109}$ Generally, these schemes call for a permanent or temporary reduction in the taxable value of farmland or a separate agricultural tax classification. ${ }^{170}$ One way of reducing the taxable value of farmland is through the use of public land use restrictions, such as exclusive farm or large-lot zoning or other more detailed growth management plans. Tax assessors may disregard such public restrictions in calculating tax value, ${ }^{171}$ because the restrictions are often temporary holding zones not truly reflective of market value. ${ }^{172}$

The solution seems obvious: mandate that local assessors value agriculturally classified property in that use until such time as development actually occurs. ${ }^{173}$ The reclassification of all undeveloped land to agricultural/open space, combined with the unearned increment recapture provisions, should sufficiently convince tax as:sessors to reduce the tax value of such property. Some tax assessors may remain unconvinced, and insist on factoring in the value of hypothetical developed uses under hypothetically-selected LUI ratings. If this occurs, such recalcitrant assessors may be convinced by appropriate legislation.

169 See generally Property Tax Preferences for Agrucultural LAND (N. Roberts and H. Brown eds. 1980); Dawson, Compassionate Taxation of Undeveloped Private Land, 3 Zoning \& Plan. L. Rep. 49, 57 (1980).

170 See, e.g., Barrows, Wisconsin's Farmiland Preservation Program (Wisconsin Department of Agriculture, Trade and Consumer Protection, Pub. No. G2890, May 1978); Ellingson, Differential Assessment and Local Governmental - Controls to Preserve Agricultural Lands, 20 S.D.L. REv. 548 (1975); Henke, Preferential Property Tax Treatment for Farmland, 53 OR. L. Rev. 117 (1974); Lapping, Bevins \& Herbers, Differential Assessment and Other Techniques to Pre.serve Missouri's Farmlands, 42 Mo. L. Rev. 369 (1977); Note, Preferential Property Tax Treatment of Farmland and Open Space Under Michigan Law, $8 \mathrm{U}$. MrCH. J.L. REF. 428 (1975).

171 See, e.g., CaL. Rev. \& TAX Code $\$ 422$ (West Supp. 1980) (providing that zoning will not be considered an "enforceable restriction" under terms of the California Constitution, CAL. ConsT. art. XIII, $\$ 8$, allowing for reduced assess-ment of "enforceably restricted" property).

172 See supra text accompanying notes 85-86.

173 Oregon has authorized exclusive farm use zones by statute, Or. REv. STAT. $\$ \$ 197.230,215.243$ (1979), and California has judicially approved of them, -Gisler v. County of Madera, 38 Cal. App. 3d 303, 112 Cal. Rptr. 919 (1974). 


\section{Redirecting Public Participation Toward Land Use Policy Issues}

Surprisingly little thought has been given to the role and scope of public participation in the land use process. ${ }^{174}$ Since the Standard State Zoning Enabling Act provided that "any person aggrieved" could appeal to, and any person aggrieved or any taxpayer could appeal from, the administrative determinations of the board of adjustment, ${ }^{175}$ while also according significant deference to the views of neighbors, and occasionally all taxpayers, with respect to local legislative action, ${ }^{176}$ the role of the neighbor has been assumed to be indispensable. Moreover, to the extent that land use decisions may be the subject of initiatives or referenda, the neighbor's role in policy application under the existing system is superior to that of the legislative body. ${ }^{177}$

\section{a. Misuse of Zoning for Private Purposes}

Generally, a neighbor threatened with a substantial and unreasonable interference with the use and enjoyment of his property may look to the common law of nuisance for relief. ${ }^{178}$ A successful plaintiff was traditionally entitled to injunctive relief, thereby precipitating an unnecessary conflict between a highly valued, but nuisance-creating development and a quantitatively less-injured

174 Krasnowiecki, PUD, supra note 78 , at 55.

175 SZEA, supra note $25, \$ 7$.

170 For example, section five of the SZEA requires a three-quarters majority vote of the legislative body to pass a zoning amendment if a protest is filed by owners of $20 \%$ or more either of the area of the lots included in the proposed change, or of those immediately adjacent to the rear thereof, or of those directly opposite thereto. Id. $\$ 5$.

Professor Krasnowiecki notes that most enabling statutes are silent about neighbor review of local legislative action, "yet the neighbor has been accorded standing." Krasnowiecki, PUD, supra note 78, at 56. Neighbors often are allowed to test the propriety of zoning action by means of an action for declaratory judgment or injunction. Id. 56 n.23. Professor Krasnowiecki points out that the risk of frivolous lawsuits also falls on the developer: "[e]ven a slight possibility that the challenger might win will stop the developer from proceeding with the construction." Id. 55. Among other things, construction lenders will commonly have provided that litigation over the development relieves them of any obligation to pay out on the loan. See, e.g., 4A P. RoHAN, supra note 15, 3.09 [2], at 3-411 to -420 (borrower's representations and warranties as well as conditions precedent to making advances in construction loan and project agreement forms).

${ }^{177}$ See City of Eastlake v. Forest City Enterprises, Inc., 426 U.S. 668 (1976) (upholding provision of the city charter requiring referendum approval of any change in existing land uses by a $55 \%$ margin).

178 See generally J. Crubbet, Prunciples of the LaW of Property 362 (2d ed. 1975); C. Donafrue, T. Kauper \& P. Martin, Cases and Materials on PROPERTY-AN INTRODUCTION TO THE CONCEPT AND THE INSTTTUTION 978-1026 (1974); C. SMrth \& R. Boyer, Survey of the Law of Property 209 (1971). 
plaintiff. 179 Not surprisingly, the plaintiff often lost. Thus, zoning took on the role of protecting individual property interests. Regrettably, the use of zoning as a tool to protect individual property interests limits the capability of the existing system to formulate a rational land use policy for the public at large.

To protect their interests, individual property owners use zoning and zoning litigation to stop development or slow the development process. ${ }^{180}$ Individual property owners know all too well that inhibiting development constricts supply and enhances the market value of their property. In this regard, zoning ordinances impose minimum lot or building sizes or restrict apartment ${ }^{181}$ and manufactured home developments, ${ }^{182}$ not because they are legitimate

179 See, e.g., Bove v. Donner-Hanna Coke Corp., 236 App. Div. 37, 258 N.Y.S. 229 (1932) (court strained to avoid the awarding of an injunction to the plaintiff because of the high utility of the defendant manufacturer); see also Ellickson, supra note 20 , at 720 .

180 In striking down the zoning referendum provision that was ultimately validated by the U.S. Supreme Court in City of Eastlake v. Forest City Enterprises, Inc., 426 U.S. 668 (1976), the concurring opinion of Ohio Justice Stem recognized the predominant interest of the neighbors:

There can be little doubt of the true purpose of Eastlake's charter provision-it is to obstruct change in land use, by rendering such change so burdensome as to be prohibitive. The charter provision was apparently adopted specifically, to prevent multi-family housing, and indeed was adopted while Forest City's application for rezoning to permit a multifamily housing project was pending before the City Planning Commission and City Council. The restrictive purpose of the provision is crudely apparent on its face. . . The proposed change must receive, rather than a simple majority, at least a 55 percent affirmative vote. Finally, the owner of the property affected is required to pay the cost of the election, although the provision gives no hint as to exactly which costs would be billed to a property owner.

There is no subtlety to this; it is simply an attempt to render change difficult and expensive under the guise of popular democracy.

City of Eastlake v. Forest City Enterprises, Inc., 41 Ohio St. 2d 187, 199-200, .324 N.E.2d 740, 748 (1975) (Stern, J., concurring), rev'd, 426 U.S. 668 (1976). 181 See, e.g., Appeal of Girsh, 437 Pa. 237, 263 A.2d 395 (1970). Much of the opposition to apartments is based on erroneous and emotional appeals that treat modern apartment developments as equivalent to the worst big city tene.ments of the 1920's. Very little evidence exists to suggest that apartments "do not pay their own way," create fire hazards, become slums, lower property values, attract transients and low class individuals, or destroy the character of the community. If anything, existing evidence is to the contrary. See Babcock \& Bosselman, Suburban Zoning and the Apartment Boom, 111 U. PA. L. REv. 1040, 1062-72 (1963); County \& Municipal Governanent Study Commission, State - of New Jersex, Housing \& Suburbs; Fiscal \& Soctal Impact of Multifamily Development 1-12 (9th Rep. 1974).

182 See, e.g., Vickers v. Towmship Comm., 37 N.J. 232, 181 A.2d 129 (1962) (upholding a rezoning which prevented the development of a trailer camp or - mobile home community even though the rezoning effectively barred such use from the entire municipality and plaintiff's proposed development was shown not to be detrimental to the immediate neighborhood as it then existed), cert. denied, 371 U.S. 233 (1963). While the case law is not uniformly against mobile homes, see, e.g., Town of Glocester v. Olivo's Mobile Home Court, Inc., 111 R.I. 120, 
nuisances, but because these protect neighbor expectations of property appreciation-expectations premised upon restricting the entrance and competition of comparable land uses in the market. One recent study by Professor Nelson concluded that despite zoning's contrived nuisance-protection justification, it is really a tool employed by some property owners to control the property of others. ${ }^{183}$ Professor Nelson further argued that zoning is inconsistent with basic American beliefs and individual freedom. ${ }^{184}$

The courts, in contrast, refused for a considerable period to acknowledge that individual property interests, and not public policy, was the basis of many zoning decisions. A court would find itself in the awkward position of articulating, and accepting in view of the presumed validity of legislative acts, patently ridiculous justifications for zoning enactments. Time and again, one and two acre minimum lot sizes are deemed necessary to prevent the spread of fire and disease, ${ }^{185}$ notwithstanding that millions of individuals in both urban and suburban areas live on much smaller lots free from immolation or the plague.

In recent years, courts have become less tolerant of contrived justifications for upholding zoning enactments. This has been especially the case when individual property owners have used zoning not only to serve their superior economic positions, but also to keep the community free of certain racial, ethnic, or economic classes. ${ }^{186}$ The Supreme Court has held that zoning decisions resulting from a demonstrated racial intent constitute an equal protection violation. ${ }^{187}$ Moreover, a zoning decision that has a racial effect, even

300 A.2d 465 (1973) (invalidating a zoning ordinance that prohibited the use of land for a mobile home park in excess of 30 units), it is generally true that mobile homes have been excluded from residential districts and relegated to commercial and industrial areas. D. MANDELKER \& R. CunntnghaM, supta note 22, at 368 .

183 R. Nelson, supra note 61 , at 16.

184 Id. $119-20$.

185 In Simon v. Town of Needham, 311 Mass. 560, 42 N.E.2d 516 (1942), the court upheld one acre lots because, inter alia, "the danger from fire from outside sources might be reduced." Id. at 563,42 N.E.2d at 518 . Other rationalizations for large lot zoning include the inducement to the cultivation of flowers, id.; preservation of a rural appearance, Gignoux v. Village of Kings Point, 199 Misc. 485, 491-92, 99 N.Y.S.2d 280, 286 (Sup. Ct. 1950); preservation of the capacity of the soil to absorb rainfall, Bogert $v$. Township of Washington, 25 N.J. $57,64,135$ A.2d 1, 5 (1957); creating an elementary school of the ideal size, Padover v. Township of Farmington, 374 Mich. 622, 636, 132 N.W.2d 687, 694 (1965); the preservation of the water supply, Zygmont v. Planning \& Zoning Comm'n, 152 Conn. 550, 210 A.2d 172 (1965), and providing for some "high class" residential areas, Clary v. Borough of Eatontown, 41 N.J. Super. 47, 124 A.2d 54 (1956).

186 Blumstein, supra note 168 , at 48.

187 Village of Arlington Heights v. Metropolitan Hous. Dev. Corp., 429 U.S. 252, 265 (1977). A showing that a discriminatory purpose motivated the land 
apart from a racial intent, may constitute a violation of the Fair Housing Act. ${ }^{188}$ Some state courts, notably New Jersey, have relied upon state concepts of due process and equal protection to invalidate zoning ordinances that fail to provide for the community's fair share of low and moderate income housing ${ }^{189}$ or that contain re-

use decision, however, does not complete the court's analysis. The local community still has the opportunity to establish that the "same decision would have resulted even had the impermissible purpose not been considered." Id. 270 n.21.

188 Metropolitan Hous. Dev. Corp. v. Village of Arlington Heights, 558 F.2d 1283, 1290 (7th Cir. 1977), cert. denied, 434 U.S. 1025 (1978); accord Resident Advisory Bd. v. Rizzo, 564 F.2d 126, 146-48 \& n.31 (3d Cir. 1977), cert. denied, 435 U.S. 908 (1978); United States v. City of Blackjack, Mo., 508 F.2d 1179, 1184-85 (8th Cir. 1974), cert. denied, 422 U.S. 1042 (1975).

Although the circuit courts uniformly agree that evidence of racial effect may constitute a prima facie case under the Fair Housing Act, 42 U.S.C. $\$ \$ 3601-3631$ (1976 \& Supp. III 1979), the circuits are not in agreement with respect to the analytical approach adopted for evaluating whether a plaintiff has proven a violation. For example, in City of Blackjack, the Eighth Circuit found that after a racial effect is shown by the plaintiff, the burden shifts to the government to show that its conduct promotes a compelling state interest. 508 F.2d at 1185. In contrast, the Third Circuit has sought to avoid placing this heavy burden upon the government and instead requires that the government demonstrate "that no alternative course of action could be adopted that would enable that interest to be served with less discriminatory impact." Rizzo, 564 F.2d at 149.

The Seventh Circuit has adopted an even more elaborate analytical scheme balancing four factors: the strength of the plaintiff's showing of discriminatory effect; whether there is some evidence of discriminatory intent; the interest of the defendant in taking the action that causes the discriminatory effect, and the nature of the relief sought-that is, whether the plaintiff seeks to compel the defendant to construct integrated housing or whether the plaintiff is merely attempting to prevent the defendant from interfering with the construction of integrated housing on his own land. Arlington Heights, 558 F.2d at 1290-93.

189 In Southern Burlington County NAACP v. Township of Mt. Laurel, 67 N.J. 1.J1, 336 A.2d 713, appeal dismissed, 423 U.S. 808 (1975), the court stated:

[W] hen it is shown that a developing municipality in its land use regulations has not made realistically possible a variety and choice of housing, including adequate provision to afford the opportunity for low and moderate income housing or has expressly prescribed requirements or restrictions which preclude or substantially hinder it, a facial showing of violation of substantive due process or equal protection under the state constitution has been made out and the burden, and it is a heavy one, shifts to the municipality to establish a valid basis for its action or nonaction.

Id. at $180-81,336$ A.2d at 728 . Once the burden is shifted to the municipality, it cannot be satisfied, as it can in the federal court, see supra note 187, merely by showing a permissible motivation or legitimate policy objective. Rather, the municipality must demonstrate an overriding governmental interest and specific means aimed at achieving that overriding interest. 67 N.J. at $174 \&$ n.10, 336 A.2d at 724-25 \& n.10. The Mt. Laurel decision triggered an avalanche of commentary. See, e.g., Ackerman, The Mount Laurel Decision: Expanding the Boundaries of Zoning Reform, 1976 U. Ir工. L.F. I; Mallach, Do Lawsuits Build Housing?: The Implications of Exclusionary Zoning Litigation, 6 Rut.-CAM. L.J. 653 (1975); Payne, Delegation Doctrine in the Reform of Local Government Law: The Case of Exclusionary Zoning, 29 RuT. L. Rev. 803 (1976); Rose, Exclusionary Zoning and Managed Growth: Some Unresolved Issues, 6 Rut.-CaM. L.J. 689 (1975); Note, Exclusionary Zoning and Timed Growth: Resolving the Issue After Mount Laurel, 30 Rut. L. Rev. 1237 (1977). Much of the commentary criticizes the notion of 
strictions that impede the production of least cost housing. ${ }^{190}$

These substantive due process and equal protection decisions. are both welcome and regrettable. Because such decisions highlight the misuse of zoning for the protection of individual property interests, the decisions are well-founded. To the extent that they represent the substitution of judicial for legislative policymaking, however, they augur badly. Courts are poorly equipped to undertake the factfinding and analysis necessary to evaluate and accommodate the conflicting demands on a community's property resources. For example, after a brief and frustrating experience with judicial activism, the New Jersey Supreme Court appears to have recognized the limits of judicial capability by agreeing to hear, on a consolidated basis, more than a dozen cases seeking clarification of its earlier decisions. ${ }^{101}$

\section{b. Piercing the Zoning Charade}

If one accepts the argument that neighbors have used zoning to foster their individual interests rather than public policy, two alternatives present themselves: either expressly authorize neighbor control or expressly eliminate it. Professor Nelson has chosen the first alternative; ${ }^{192}$ the second is adopted here.

\footnotetext{
"fair share," 67 N.J. at 174, 336 A.2d at 724, for its ambiguity. In particular, after Mt. Laurel, the government was left to ponder the extent of its duty to provide housing for underserved population groups. See Blumstein, supra note 168, at 26. 180 Oakwood at Madison, Inc. v. Township of Madison, 72 N.J. 481, 495 \& n.3, 512, 371 A.2d 1192, 1198 \& n.3, 1209 (1977). In adopting the notion that municipalities should be under an obligation to adjust their zoning regulations to render the production of least-cost housing feasible, the New Jersey court recognized that developing municipalities do not have an affirmative obligation actually to construct or to sponsor housing projects for low and moderate income individuals. The court viewed its role as one of promoting the concept of "filtering," which suggests that an overall increase in housing stock will ultimately work to the benefit of lower income groups as higher income families move to new units, reducing the demand for, and thus the price of, older units. See W. Grugsby, Housing Markets and Public Policy 84-i30 (1963); C. Hartman, Housing and Soctal Policy 62-63 (1975); J. Lansing, C. CuIfton \& J. Morgan, New Homes and Poor People: A Study of Cerans of Moves (1969); Fisher \& Winnick, A Reformulation of the "Filtering" Concept, $7 \mathrm{~J}$. Soc: Issues 47 (195I).

191 Urban League of Greater New Brunswick v. Mayor and Council, 142 N.J. Super. 11, 359 A.2d 526 (1976), rev'd on other grounds, 170 N.J. Super. 461, 406 A.2d 1322 (1979), cert. granted, 82 N.J. 283, 412 A.2d 789 (1980). The court apparently will clarify its earlier decisions in Mount Laurel, see supra note 189, and in Oakwood, see supra note 190. The latter decision itself represented a narrowing of the judicial role and something of an admission of its limitations in the land use area. As the court stated: "[T]he governmental-sociological-economic enterprise of seeing to the provision and allocation throughout appropriate regions of adequate and suitable housing for all categories of the population is much more appropriately a legislative and administrative function rather than a judicial function to be exercised in the disposition of isolated cases." Oakwood, 72 N.J. at 534, 371 A.2d at 1218 (footnote omitted).
}

192 R. Nelson, supra note 61. 
Nelson declares the public policy nature of zoning to be a sham, ${ }^{193}$ and neighbors, rather than the legislature or zoning board, are expressly given control over the property of adjacent landowners. Characterizing the zoning power as a collective property right, Nelson would transfer that right to a neighborhood association in which all of the individual owners in the neighborhood have "shares." 194 If the owner of undeveloped land within association boundaries wanted to develop, the owner could buy the necessary collective property rights from the association if a substantial majority of the association members approved.

Nelson's proposal validly exposes the artificial public image of zoning and would permit greater land use flexibility, because the sale of collective rights would more likely coincide with the marketplace than with zoning. The proposal, however, perpetuates the existing system's infringement of individual freedom. ${ }^{195}$ The individual is sacrificed to a neighborhood association instead of being sacrificed to the legislature.

The alternative system is predicated upon the antithesis of Professor Nelson's prediction that "in future social systems personal rights may be increasingly superseded by collective rights." 198 In the words of John Rawls, the alternative system seeks to create an allocation device free of "the effects of specific contingencies which put men at odds and tempt them to exploit social and natural circumstances to their own advantage." 197 To do this, public participants in the legislative process and the legislators themselves are urged to evaluate various land use policies on the basis of general considerations, rather than on how they will affect their own particular situation. Specifically, the alternative system allows public participation at the policymaking stage only, ${ }^{188}$ and does away with neighbor involvement in policy application altogether. All regis-

193 In Professor Nelson's words, “[z]oning [is] supported by fictions, evasions, contrived arguments, and other dodging of the fundamental issues." Id. 121.

194 Id. 213.

105 See Kmiec, Private Control of Collective Property Rights (Book Review), 13 VAL. U.L. REv. 589, 594 (1979).

196 R. NELSON, supra note 61, at 119.

$197 \mathrm{~J}$. Rawis, A Theory of Justice 136 (1971).

198 Public participation is important at the policymaking stage. It allows individual citizens and developers the opportunity to evaluate the planner's conception of how, where, when, and to what intensity the community should expand. Here, the public can directly contribute their thoughts concerning the public improvement needs of the community. Once members of the public have communicated their interests to their elected representatives, however, the alternative system looks to those representatives to translate community sentiment into public policy. 
tered voters within the jurisdiction would be invited by mailed notice to participate in a series of legislative hearings on the formulation of the community's intensity policy. On the basis of these hearings and the advice of the community's planning consultants, the legislative body would then publish the LUI rating schedules. If neighbors are dissatisfied with the formulated policy, they are encouraged to use their traditional ballot box remedy.

With regard to policy application, unlike zoning and other existing land use controls, the alternative system does not apply public policy to individual landowners. Rather, land use policy under the alternative system is voluntarily accepted. The alternative system neither prescribes permitted uses nor mandates an intensity level for any specific parcel; instead, it allows the individual landowner to select an intensity level from an available range of possibilities. Thus, actual land use itself is a function of individual choice and market demand.

\section{c. Residual Neighbor Protection}

Although it is recognized that a landowner may select a type of development inimical to surrounding existing development, market forces, the general deterrence of the common law of nuisance, and public control over public improvements ${ }^{199}$ are relied upon to minimize the chances of a substantial conflict. As indicated earlier, strong evidence suggests that the locational land use patterns established by the market differ little from those imposed by the existing system. Few, if any, developers desire to create nuisances; however, imperfect information or inadequate moral or economic incentives may result in externalities or spillovers being imposed upon neighboring properties. Where externalities do exist, modern nuisance law theories provide a reasonable remedy. Whereas nuisance law was at one time characterized as an "impenetrable jungle," 200 many of its imperfections are easily remediable by a deemphasis of injunctive relief. ${ }^{201}$ Through the use of permanent damages, compensated injunctions, and injunctions dissolvable upon the payment of damages, courts would be better able, and more willing, to provide relief that is capable of both determining fault and efficiently resolving the conflict. ${ }^{202}$

190 See supra text accompanying notes 141-42.

200 W. Prosser, The LAW of Torts $\$ 86$, at 571 (4th ed. 197I).

201 See supra note 179 and accompanying text.

202 See, e.g., Boomer v. Atlantic Cement Co., 26 N.Y.2d 219, 257 N.E.2d 870, 309 N.Y.S.2d 312 (1970). For an elaborate reformulation of nuisance law to promote efficiency, see Ellickson, supra note 20, at 719-61. See generally Calabresi 
Frequently, many of the complaints articulated by neighbors at zoning hearings relate to such public improvement matters as water run-off, sewage disposal, traffic patterns, and school overcrowding. ${ }^{203}$ Under the alternative system, all of these matters are directly controlled by LUCA. To the extent of the unearned increment, a landowner can be mandated to construct public facilities that should alleviate any identified problem. Moreover, because these matters. demand some professional training or experience for evaluation, LUCA-rather than the neighbor-is given the responsibility. Neighbors have strong incentives to misuse the public improvement issue in order to mask anticompetitive "no growth" attitudes or to object to housing units that might attract the "wrong element" to the community; ${ }^{201}$ thus, LUCA is made responsible for these decisions.

\section{d. Protection of the Housing Consumer}

Some questions may be raised concerning the protection of housing consumers under the alternative system. Certainly, one of the assumptions made by stringent subdivision plat review under the existing system is that housing consumers are incapable of

\& Melamed, Property Rules, Liability Rules, and Inalienability: One View of the Gathedral, 85 Harv. L. Rev. 1089 (1972); Rabin, Nuisance Law: Rethinking Fundamental Assumptions, 63 VA. L. REv. 1299 (1977).

$203 \mathrm{~A}$ recent book intended to advise laymen on zoning skills recommended that opponents of a zoning amendment always raise the effect of the proposed land: use on public facilities. The authors note:

Members of the civic club have files of current information on the capacity of water lines, sewer lines, storm drainage, schools, and streets. After learning the details of any new zoning proposal, they descend on city hall to ask the professionals there pointed questions about the impact that the proposal is likely to have. The answers given them are used to develop arguments against the proposal.

D. Hinds, N. Carn \& O. Ordway, Winning ax Zoning 139 (1979).

204 These public facility arguments frequently are made by homeowners of a high socioeconomic status, and one often can question the substantive validity of the articulated concerns. It has been noted, for example, that:

Current land use control policies-or the lack thereof-did not arise from happenstance. They persist because they serve the interests of politically active citizens. Local zoning ordinances, building codes, subdivision controls, and statutes on annexation and municipal incorporation have apparently served certain values and interests of citizens of above average [socioeconomic status] well. The "quality" of their neighborhoods has been protected from invasion by undesirable citizens, land uses, and low-cost or multiple-dwelling units. Property values have not only been protected but have risen. Variance procedures have been sufficiently responsive to block undesired developments in their neighborhoods but permit higher [socioeconomic status] citizens to profit from speculation and development.

D. Ervin, J. Fitch, K. Godwin \& W. Sherard, Land Use Control 33 (1977), reprinted in D. HAGMAN, supra note 19, at 225; see also R. BABCOCK, supra note 27 , at $148-50$. 
making proper housing choices. With regard to design and use questions, the alternative system eschews this paternalistic assumption. For example, if there is a market demand for modern, highrise condominiums, the alternative system would expect to see condominiums in a variety of architectural styles voluntarily produced by landowners. From the supply of units produced, the housing consumer is best qualified to address his own design and use preferences.

In contrast, housing consumers are not generally knowledgable on the safety, durability, and comparative advantages of various construction materials or techniques. The consumer, however, has not lacked protection. A majority of jurisdictions has enacted some type of building code. ${ }^{205}$ These codes typically regulate structural, electrical, heating, plumbing, mechanical, energy, fire safety, and gas installations. In addition, most states statutorily require the licensing of architects, construction contractors, electricians, engineers, plumbers, and others involved in the building trade. ${ }^{206}$ Separate health codes often deal with sewage, drainage, light, and ventilation. These codes are more than adequate to protect the safety of the housing consumer and to redress the knowledge imbalance between consumer and developer. If anything, evidence suggests that "increasing regulation is slowing down the building process and making the adoption of current and new potentially cost-saving ideas more difficult and expensive." 207

New housing consumers are also protected by implied warranties of quality, which are now applicable in approximately thirty states. ${ }^{203}$ These implied warranties have their origin in both contract and tort law. To the extent that the implied warranty is viewed as a contract remedy, it has displaced the doctrine of caveat

205 See U.S. Dep'T of Housing and Urban Development, Final Report of THE TASK Force on Housing Costs 35 (1978) [hereinafter cited as Repont on Housing Costs].

206 See Advisory Comm'n on Intergovernmental Relatrons, Bumding Codes: A Program for Intergovernatental Reform 12 (1966).

207 See Report on Housing Costs, supra note 205, at 35.

208 Comment, Home Sales: A Crack in the Caveat Emptor Shield, 29 MERCER L. REv. 323, 330 n.43 (1977). On implied housing warranties in general, see Bearman, Caveat Emptor in Sales of Realty-Recent Assaults Upon the Rule, 14 VAND. L. Rev. 541 (1961); Bixby, Let the Seller Beware: Remedies for the Purchase of a Defective Home, 49 J. URB. L. 533 (1971); Haskell, The Case for an Implied Warranty of Quality in Sales of Real Property, 53 GEo. L.J. 633 (1965); McNamara, The Implied Warranty in New-House Construction Revisited, 3 ReAL EsT. L.J. 136 (1974); McNamara, The Implied Warranty in New-House Construction: Has the Doctrine of Caveat Emptor Been Abolished?, 1 REAL EsT. L.J. 43 (1972); Roberts, The Case of the Unwary Home Buyer: The Housing Merchant Did It, 52 CORNELL L. Rev. 835 (1967). 
emptor for new housing consumers and, in some cases, second purchasers as well. ${ }^{209}$ Tort law extends similar protection to purchasers of used housing under a strict liability theory. ${ }^{210}$ Courts have not demonstrated any willingness to permit builders either to disclaim the implied warranty or to substitute a more limited express warranty. ${ }^{211}$ Builders have been found liable for construction defects, soil problems, and resultant personal injuries. Although few states have codified the requirements for home warranties, ${ }^{212}$ market competition and the judicial implication of these remedies have dramatically extended the warranty's availability.

\section{e. Due Process Objections to Reducing the Neighbor's Role}

It may be argued that redirecting the neighbor toward policy and away from individual application violates constitutional due process. Clearly, the alternative system runs directly contrary to current interpretations of existing enabling legislation. ${ }^{213}$ The alternative system, however, assumes the repeal of existing zoning and subdivision enabling acts and the substitution of more compatible legislation. Nevertheless, compatible enabling legislation may be inadequate support for the alternative system if constitutional due process requires extensive public participation.

The requirements of constitutional due process in the land use context are unclear and unsettled. It is a fair statement of the case law, however, that the neighbor is to be afforded notice and a reasonable opportunity to be heard when the land use decision is made in a quasi-judicial, rather than a legislative, proceeding and when the

209 See Barnes v. Mac Brown \& Co., 264 Ind. 227, 342 N.E.2d 619 (1976). But see Oliver v. City Builders, Inc., 303 So. $2 \mathrm{~d} 466$ (Miss. 1974). See generally Note, Builders' Liability for Latent Defects in Used Homes, 32 STaN. L. Rev. 607 (1980).

210 See, e.g., Schipper v. Levitt \& Sons, Inc., 44 N.J. 70, 207 A.2d 314 (1965) (imposing strict liability on a mass production home developer for the failure to install a mixing valve to moderate water temperatures, resulting in the scalding of a 16-month-old boy); Kriegler v. Eichler Homes, Inc., 269 Cal. App. 2d 224, 74 Cal. Rptr. 749 (1969) (imposing strict liability on a home developer in favor of a second purchaser when a faulty radiant heating system reduced the valve of the house by more than $\$ 5000)$. Thus, strict liability has been found for both personal and property injuries.

211 See, e.g., Smith v. Berwin Builders, Inc., 287 A.2d 693 (Del. Super. Ct. 1972); Smith v. Old Warson Dev. Co., 479 S.W.2d 795 (Mo. Sup. Ct. 1972) (en banc); Staff v. Lido Dunes, Inc., 47 Misc. $2 d$ 322, 262 N.Y.S.2d 544 (Sup. C. 1965).

212 A few states have done so. See, e.g., MD. Real Prop. Code ANN. \$\$10201 to -205 (West Supp. 1980); N.J. Rev. Stat. $\$ \$ 46: 3 B 1-: 3 B 12$ (1977). Federal warranty law also may apply to consumer products intended to be attached or installed in real property. See generally Peters, How the Magnuson-Moss Warranty Act Affects the Builder/Seller of New Housing, 5 REAL EsT. L.J. 338 (1977).

213 See Krasnowiecki, PUD, supra note 78, at 55-56 nn.22-24. 
decision might constitute a substantial or significant deprivation of a property right. ${ }^{214}$ It is not entirely certain, however, when a proceeding is "legislative" and when "judicial," or what constitutes a "substantial" deprivation of property.

(i) The Type of Government Proceeding

That the nature of the government function will dictate the procedure required by due process has long been settled by the Supreme Court. ${ }^{215}$ When a government proceeding requires determinations of fact and the issuance of orders premised upon evidentiary findings, the proceeding is judicial or quasi-judicial in nature and requires notice, a hearing, and perhaps a wide range of other rights guaranteed by due process. ${ }^{216}$ In contrast, when a proceeding is for promulgating policy-type rules or standards, the proceeding is legislative or quasi-legislative in character, and absent a statutory mandate to the contrary, the notice and hearing requirements of due process do not apply. ${ }^{217}$

These basic distinctions have been muddled by federal and state court decisions. For example, in South Terminal Corp. v. EPA, ${ }^{218}$ the First Circuit found that an implementation plan under the Clean Air Act which would apply to one particular polluter was nevertheless a legislative act not requiring a hearing because the result of the administrative process was a general policy that would apply prospectively. The court's characterization is somewhat disingenuous, however, because it imposed substantial liability on only one entity. Similarly in state courts, small tract zone amendments

214 See Cunningham, Due Process Safeguards Mandated for Land Use Hearings, 2 Cax. Real Prop. L. RPtr. 129, 130 (No. 8, 1979) (discussing Horn v. County of Ventura, 24 Cal. 3d 605, 596 P.2d 1134, 156 Cal. Rptr. 718 (1979), in which the California Supreme Court held that a neighbor plaintiff who purchased property after a tentative subdivision map had been approved for adjacent property was entitled to notice and a reasonable opportunity to be heard prior to the final approval of the subdivision). Compare Bi-Metallic Inv. Co. v. State Bd. of Equalization, 239 U.S. 441 (1915) (no right of hearing exists in connection with an overall assessment increase applicable to all properties) with Londoner v. City of Denver, 210 U.S. 373 (1908) (property owner has a constitutional right to be heard in reference to an assessment levied against his particular property).

215 Morgan v. United States, 304 U.S. 1 (1938).

210 See generally Mathews v. EIdridge, 424 U.S. 319 (1976).

217 In United States v. Florida E. Coast Ry., 410 U.S. 224 (1973), the Court stated that '[ $t]$ he term 'hearing' in its legal context undoubtedly has a host of meanings. Its meaning undoubtedly will vary, depending on whether it is used in the context of a rulemaking-type proceeding or in the context of a proceeding devoted to the adjudication of particular disputed facts." Id. 239 (footnote omitted). 
and subdivision approvals are often treated as legislative acts, even though ultimate determination in these cases depends upon the application of general policy to specific parcels. ${ }^{219}$ Some states have recently reappraised the legislative/quasi-judicial distinction, finding governmental proceedings that result in the discretionary application of general standards to particular parcels of property to be quasi-judicial, even if the decision was reached in a legislative forum. ${ }^{220}$

Given that it may be difficult to know when a proceeding is legislative or quasi-judicial, one needs to know whether the distinction is of constitutional dimensions. Again, however, the courts appear divided. Whereas a majority of state courts regard a statutory characterization or the absence of notice and hearing provisions in enabling acts to be conclusive, ${ }^{221}$ some courts have found the quasi-judicial label and the procedural protections that flow therefrom to be mandated by constitutional principle. ${ }^{222}$

219 See Cunningham, supra note 214, at 130-31. The characterization of zoning matters as legislative acts has traditionally prevented a court from mandating a particular use after a finding that the existing zoning classification is unreasonable, arbitrary, and confiscatory. In Stilbell Realty Corp. v. City of New York, 54 A.D.2d 962, 388 N.Y.S.2d 648 (1976), the court noted that a confiscatory zoning ordinance should be replaced by an appropriate zoning classification determined by the legislative body rather than the court. Accord Guhl v. Holcomb Bridge Rd. Corp., 238 Ga. 322, 232 S.E.2d 830 (1977); Brunette v. County of McHenry, 48 Ill. App. 3d 396, 363 N.E.2d 122 (1977). Contra Dade County v. Beauchamp, 348 So. 2d 53 (Fla. Dist. Ct. App. 1977). See generally 4 R. Andenson, supra note 13, \$28.10; Rosenzweig, From Euclid to Eastlake: Toward a Unified Approach to Zoning Change Requests, 82 Drck. L. Rev. 59 (1977).

220 See, e.g., Snyder v. City of Lakewood, 189 Colo. 421, 542 P.2d 371 (1975) (en banc); Sabo v. Monroe Township, 394 Mich. 531, 232 N.W.2d 584 (1975); West v. City of Portage, 392 Mich. 458, 221 N.W.2d 303 (1974); Fasano v. Board of County Comm'rs, 264 Or. 574, 507 P.2d 23 (1973) (en banc); Fleming v. City of Tacoma, 81 Wash. 2d 292, 502 P.2d 327 (1972) (en banc); cf. Maricopa County Bd. of Supervisors v. Bell 51st Investors, 108 Ariz. 261, 495 P.2d 1315 (1972) (en banc) (Planning and Zoning Commission must hold public hearings prior to recommending zoning changes). See generally Freilich, Fasano v. Board of County Commissioners of Washington County: Is Rezoning an Administrative or Legislative Function?, 6 Urb. Law. vii (1974); Land Use, Planning and Zoning, 8 URB. LAw. 747, $780-83$ (1976); Comment, supra note 57.

221 See Cunningham, supra note 214, at 131.

222 See, e.g., Horn v. County of Ventura, 24 Cal. 3d 605, 596 P.2d 1134, 156 Cal. Rptr. 718 (1979). One commentator has stated absolutely that "whether rezoning a specific parcel of land is an administrative decision which therefore requires due process standards . . . is a matter of constitutional, not state, law." Developments in the Law-Zoning, 91 HaRv. L. REv. 1427, 1540 (1978) (footnote omitted). In light of City of Eastlake v. Forest City Enterprises, Inc., 426 U.S. 668 (1976), this would appear to be an overstatement. The Court in Eastlake relied on the Ohio Supreme Court's earlier discussion of the rezoning process to determine that "the City Council's action in rezoning respondent's eight acres . . . was legislative in nature." Id. 673 (footnote omitted). The Court further suggested that it was bound by this finding as an interpretation of state law. $1 d$. 674 n.9. 


\section{(ii) The Nature of the Interest Threatened}

Procedural due process requirements are often triggered when the governmental proceeding threatens a substantial deprivation of significant property rights. Knowing what deprivations are substantial and what property rights are significant, however, is even more difficult than determining the difference between a legislative and quasi-judicial proceeding. As might be expected, the state courts are again divided. California decisions appear to presume the significance of property interests that are alleged to be deprived in land use pleadings. ${ }^{223}$ Other state courts have refused to afford notice and hearing protections to neighbors when only aesthetic sensibilities are offended or when the property deprivation is insubstantial-that is, less than a taking. ${ }^{224}$

(iii) Judicial Evaluation of Neighbor Property Interests Under the Existing System

The significance of the neighbor's property interest has always. troubled American courts in land use controversies, although courts have seldom assessed the difficulty directly. Typically, courts face one of two types of land use cases: those brought by landowners challenging denials of development permission and those brought by neighbors challenging grants of development permission. Court review in the landowner-initiated case presents little problem: the court balances the well-defined landowner interest against the community's interest in the public law or regulation, and the landowner generally loses.25 Court review in the neighbor-initiated case is more problematic. The neighbor's interest is not well-defined; hence, it is difficult for the court to know what to weigh against the public law or regulation, which in this case favors, rather than opposes, development. Consistency would seem to require that, just as the landowner's individual property interest must give way to the public policy against development in the landowner-initiated

223 See Horn, 24 Cal. 3d at 615, 596 P.2d at 1139, 156 Cal. Rptr. at 723.

224 E.g., McGrady v. Callaghan, 244 S.E.2d 793 (W. Va. 1978) (adjoining landowners are not entitled to notice and hearing on the basis of an allegation of aesthetic loss and possible damage to their land and wells resulting from the drilling of a new surface mine on an adjoining property). See Cunningham, supra note 214, at 131. English land use practice agrees with this view, limiting neighbor challenges to a limited group of particularly unneighborly uses, such as. slaughter houses and landfills. See Town and Country Planning Act, 1962, ch. 38, $\$ 15$.

225 See Krasnowiecki, PUD, supra note 78, at 66-69. On the Court's attempt to balance public and private interests generally in the area of zoning, see $1 \mathrm{R}$. ANDERSON, supta note $13, \S 3.23$. 
cases, the neighbor's individual property interest must give way to the expressed.public policy in favor of development in the neighborinitiated case.

The courts, however, have not been consistent. They show a definite proclivity for striking down prodevelopment public law and regulation in the face of a neighbor challenge. ${ }^{226}$ Instead of seriously evaluating the neighbor's interests when they conflict with community policy, the courts have chosen to test the validity of the suspicious "antineighbor" public law or regulation against a few simple litmus tests. Courts inquire, for example, whether the prodevelopment public law or regulation constitutes spot zoning ${ }^{227}$ or whether it carries out the community's comprehensive plan. ${ }^{228} \mathrm{Be}-$ cause these litmus tests assume that the only "good" development is that which extends existing uses-that is, those currently made by the neighbors-the courts are ultimately able to uphold the neighbors' property interests without appearing totally to disregard the public law or regulation. Regrettably, the litmus test application fails to consider the significance of the neighbors' property interest.

\section{(iv) Applying Due Process Concepts to the Alternative System}

Within the context of the alternative system, the individual property interests of neighbors are dealt with in a policymaking, rather than a policy-applying, process. Specifically, the neighbor is afforded an opportunity to advocate public policy that coincides with his individual interests at legislative hearings held periodically

226 Professor Krasnowiecki comments:

[I]n the typical case, if the neighbor suffers loss, it will be . . . (1) because his home is worth less if there is any residential development next door; and (2) because in this development there are homes on smaller lots or garden apartments bringing with them perhaps a different kind of people. . . . [U]nder our system of zoning, the competition in housing matters is weighted heavily in favor of the existing resident and against the newcomer. What we are dealing with is an existing resident who is seeking the help of the courts against the intrusion of additional housing approved by his elected officials.

Krasnowiecki, PUD, supra note 78 , at 73 .

Professor Anderson suggests that the burden of justifying a rezoning is on the developer only in those jurisdictions that literally insist upon a proof of change or mistake in support of a zoning amendment. 1 R. ANDERson, supra note $13, \$ 5.07$. The cases cited by Anderson in which prodevelopment rezoning is judicially reversed on the basis of a spot zoning theory or a claim that the zoning is inconsistent with the comprehensive plan indicate, however, that in reality the burden of justifying a prodevelopment rezoning is often on the developer. See, e.g., Kuehne v. Town Council, 136 Conn. 452, 72 A.2d 474 (1950); Green v. County Planning \& Zoning Comm'n, 340 A.2d 852 (Del. Ch. 1974); Manley v. City of Maysville, 528 S.W.2d (Ky. 1975).

227 See generally I R. ANDERson, supra note 13, $\$ 5.08$.

228 See Fasano v. Board of County Comm'rs, 264 Or. 574, 507 P.2d 23 (1973) (en banc). 
to determine the community's LUI policy. Because that LUI policy is legislatively determined, constitutional doctrine premised on the type of proceeding involved would not appear to mandate procedural due process. ${ }^{229}$ Nevertheless, because neighbor input at this stage is considered important, notice and an opportunity to be heard would be afforded neighbors expressely under the alternative system's enabling legislation.

The alternative system does not encompass any governmental proceeding of the traditional quasi-judicial type; thus, it might seem as if the structure of the alternative system avoids this constitutional issue. The negotiation of Public Improvement and Intensity Modification Contracts, however, involves the exercise of judgment and the careful balancing of conflicting interests, which are the hallmarks of adjudication. These contractual negotiations may affect individual property interests, and if the interests are significant and substantially threatened, constitutional objections can be anticipated if notice and an opportunity to be heard are not provided.

Because the landowner is a party to both negotiations, his interests are adequately protected. The alternative system, however, excludes the neighbor from this part of the land use process on the assumption that his interests will be well protected by market forces, nuisance remedies, and LUCA's pervasive control of the public improvements to be provided. ${ }^{230}$

The question still remaining is whether the neighbors' individual property interest may be constitutionally excluded from the alternative system's analogue to the adjudicatory process. In those jurisdictions that have presumed the significance of the neighbor's property interest and the substantiality of the threatened invasion, the answer is probably no. Most jurisdictions, however, have not made this presumption, but have attempted to measure the significance and degree to which the neighbor's interest may be harmed. Some courts have found no due process implications when the neighbor's aesthetic or more subjective values were offended or when the threatened harm amounted to something less than a taking.

Using the taking standard as the point at which a neighbor is entitled to constitutional procedural due process seems particularly fair. Just as the landowner has no constitutional right to a contemplated use so long as the existing use is economically viable, so too the neighbor should not be afforded constitutional relief, except when the neighbor can demonstrate that the proposed development

229 See supra note 217 and accompanying text.

230 See supra notes 199-204 and accompanying text. 
would make his property economically nonviable as that concept has been defined in the Supreme Court's taking jurisprudence. ${ }^{231}$ Using the words of the existing system, a landowner generally has no constitutionally vested right to anything more than the existing use so long as that use is economically viable. The neighbor has no greater vested right with regard to his own property interest, and no vested right whatsoever with regard to the property rights of an adjacent landowner, unless the adjacent landowner's proposed use would deprive the neighbor of an economically viable use of his land. Thus, because most neighbor claims are less signficant than a taking and because the protection provided by the alternative system should prevent substantial harms from occurring, the occasions when neighbors are constitutionally required to have notice and an opportunity to be heard would be rare.

\section{Regulating Land Use Intensity}

\section{a. Limiting the Scope of Public Regulation}

Zoning, and to a lesser extent subdivision regulation, finds its basic justification in the police power. The criteria for valid police power regulation are whether it promotes the health, safety, morals, and general welfare of the community. Under the vague general welfare banner, zoning has been used to stabilize property values, promote homogeneity of development, control competition, preserve landmarks and natural settings, refine a community's moral and aesthetic values, control population density, and maintain a community's tax base. This Article has contended that many of these matters either should not, or need not, be the subject of public regulation. Thus, the alternative system reflects a belief that it is improper to regulate competition or to impose aesthetic or social preferences, and that public regulation distorts, rather than stabilizes, values.

\section{b. Retaining Public Control of Overall Density}

Fundamentally, the alternative system assumes that public regulation should not define how land is to be used specifically, but should instead articulate general standards which ensure that land will be used-without regard to its specific use-in a manner that is safe and healthful. From the land development standpoint, safety and health issues relate to matters of population density and the 
quantity and quality of public improvements. ${ }^{232}$ The alternative system articulates safety and health standards through the determination of the LUI schedule and the supervision and specification of public improvements. Thus, the alternative system establishes a general framework for guiding private development and a mechanism for supplying complementary public improvement.

(i) Density Regulation Under the Existing System

Under the existing system, density is controlled in a multiplicity of ways. ${ }^{233}$ For example, restrictions defining the minimum size of lots, structures, height, and floor space are common. ${ }^{234}$ Density may also be subtly regulated by restrictive definitions in zoning regulations. ${ }^{235}$ An alternative measure of density that allows the developer considerable freedom to design his structure is the Floor-Area Ratio (FAR). FAR expresses the mathematical relationship between the floor space permitted and the lot area. Thus, a FAR of 1 would permit a one-story building on the entire lot, a two-story building on one-half of the lot, a four-story building on a quarter of the lot, and so forth. ${ }^{236}$

The FAR has been a favored device primarily because it accurately predicts the intensity of use or traffic generated by a given amount of floor space. Public improvement planning is greatly aided so long as the actual physical development justified by market conditions approximates the FAR permitted. Private development is also more amenable to the FAR concept than to a minimum lot size regulation. Minimum lot size is a crude, preset control that applies without regard to the particular features of the site. This produces a rather predictable and monotonous site plan.

232 See generally Deutsch, Capital Improvement Controls as Land Use Control Devices, 9 ENvTL. L. 61 (1978).

233 D. MANDel Ker \& R. CunntnghaM, supta note 22 , at 653.

234 See generally 2 R. ANDERsON, supra note 13, $\$$ 8.05-.07; D. HAGMAN, supra note $17, \$ 59$.

235 The area of most dispute has concerned the definition of "family" in zoning ordinances. Compare Village of Belle Terre v. Boraas, 416 U.S. 1 (1974) with Moore v. City of East Cleveland, 431 U.S. 494 (1977). Although the Supreme Court has allowed restrictive definitions to affect the rights of unrelated individuals, it has upheld the sanctity of the related (blood, marriage, or adoption) family. In addition, by relying upon state constitutional guarantees of privacy, some state courts have invalidated restrictive definitions of "family" that affect unrelated individuals as well. See City of Santa Barbara v. Adamson, $27 \mathrm{Cal}$. 3d 123, 610 P.2d 436, 164 Cal. Rptr. 539 (1980). For a critical commentary of restrictive zoning definitions in this area, see Note, "Burning the House to Roast the Pig": Unrelated Individuals and Single Family Zoning's Blood Relation Criterion, 58 Cornely L. Rev. 138 (1972).

${ }^{236} 1$ N. Wrinams, supra note $2, \$ 37.01$, at 683 . 
In contrast, a FAR control allows a landowner the freedom to design structures having features that are individually suited for the site. Because the FAR concept states a more precise relationship between floor space and lot area than a minimum lot size regulation, a landowner is better able to maximize the number of units produced. ${ }^{237}$ This distinction between FAR and a minimum lot size regulation is especially significant when the planned units are moderately sized and intended for individuals of low or moderate income.

(ii) The LUI System

Density would be regulated under the alternative system by the land use intensity (LUI) system originally devised by the Federal Housing Administration. ${ }^{238}$ Under the LUI system, the FAR is related to five other ratios, each expressing a ratio of some open space use to total floor area. The open space ratio (OSR) is the relationship between total floor space on a parcel and the total area left open, including parking. The OSR is then divided into four subtypes of open space: living space (open space other than parking), recreational space (living space improved for recreation), total car space (open space less living space), and occupant car space (total car space less parking for nonresidents). For each of the four land use schedules, the ratio of each of these open space ratios to FAR can be fixed, and all six of the ratios expressed as a single number or LUI rating. It is important to realize that the fixing of this "ratio of ratios" is an expression of public policy-a decision, for example, that a given floor area of residential use calls for a given area of occupant parking, a given area of recreational use, and so forth. The LUI rating will differ among uses simply because a given FAR will generate different use densities in commercial and residential use and, further, the different uses mandate different

237 For example, under a minimum lot area regulation, two lots of significantly different size may net the same number of units because one lot just had the minimum lot area required and the other was just a few square feet of lot area short of an additional unit. This disparity would not exist under the FAR concept because the number of units permitted with $X$ square feet of lot area would be either the same or just slightly more than the units permitted with a lot size of X-1 square feet.

238 Federal Housing AdMunistration, U.S. Dep't of Housing and Urban Development, FHA No. 2600, Minimum Property Standards for Multi-Famity Housing 33-65, 477-85 (1963); Federar Housing Administration, Land PlanNING BULLETIN No. 7, LAND-USE INTENSITY (1965); see also Bair, How to Regulate Planned Unit Developments for Housing-Summary of a Regulatory Approach, 17 Zonns DrG. 185, 221 (1965); Hanke, Planned Unit Development and Land Use Intensity, 114 U. PA. L. REv. 15 (1965). 
allocations of open space. ${ }^{239}$ In addition, a community may decide that certain of the ratios are inapplicable to commercial and industrial projects. For example, the occupant car and recreational space ratios would likely be excluded for commercial and industrial projects without residential elements. It can be assumed that the LUI ratings will reflect successful existing projects as well as the community's conception of normal or adequate development.

(iii) Application of the LUI System to the Alternative System

Under the alternative system, the local legislative body, with extensive public participation, will devise periodically four separate schedules of available LUI ratings. ${ }^{240}$ These schedules will apply to residential, commercial, industrial, or mixed-use projects. The LUI schedules will not apply to a limited number of uses that historically have been treated as special exceptions because of their unusual character-for example, airports and churches. These uses will continue to be treated as special exceptions. ${ }^{241}$

Within the context of the mixed-use schedule, a community may desire to set some limit on the quantity of land available for commercial or industrial development in relation to the proposed

239 The necessity for adjusting the FAR across uses is noted in 1 N. Wrriams, supra note $2, \$ 37.01$, at $685 \&$ n.3.

240 The legislative body of the community will also determine a minimum parcel or project size for LUI selection. For example, a community may decide that only landowners with parcels of 10 acres or more may make selections. Once the selection is made, of course, the landowner may subdivide the land into smaller parcels or lots for sale rather than development. In that event, the buyers of the smaller lots subsequently would be able to develop the property in any manner consistent with both the original LUI selection and the public improvements installed by the original landowner at the time of LUI selection.

A minimum parcel size for LUI selection parallels similar restrictions placed upon the Planned Unit Development under the existing system. See supra notes 95-101 and accompanying text. The minimum parcel size should encourage "project" rather than lot-by-lot development, thereby benefiting the community in terms of utility and public service planning and the developer by reason of the marketing advantages and economies of scale inherent in the larger project. In addition, establishing a minimum should reduce administrative costs.

The administrative costs of the alternative system can also be reduced by exempting auxiliary residential construction associated with the agricultural/open space classification from the rating selection process. See, e.g., ConN. GeN. STAt. \$8-18 (Supp. 1981) (the subdivision control enabling statute, which excludes "development for municipal, conservation or agricultural purposes" from the definition of "subdivision").

241 Included within this special exception category would be particularly noxious or unneighborly uses, such as landfills and slaughter houses. See supra note 224 and accompanying text. The special exception mechanism would not be used to permit the location of "convenience" commercial uses in residentially zoned areas, as is done under conventional zoning. Thus there would be no public control of the location of gas stations, convenience markets, or laundromats. For a discussion of the special exception or conditional use device, see supra text accompanying notes 91-94. 
residential development and the overall size of the site. ${ }^{242}$ For example, if a mixed residential-commercial development contains in excess of one hundred dwellings, then 25,000 square feet of commercial space may be provided, either separate from, or as part of, the residential structures. Presumably, the exact quantity of each use permitted within the context of a mixed use project will reflect the community's assessment of its relative need for housing or employment or both. The quantity will also reveal how vigorously it desires to pursue a land use policy that forgoes the sanctity of the zoning district in favor of a land use policy that recognizes that separating the work force from its place of residence is not only poor energy planning, but also in many cases unnecessary from a health or safety standpoint.

As previously mentioned, the LUI schedules form the basis of the community's land use policy. From any of these schedules, a landowner may select an LUI rating just prior to development. Thus, a private decision, not public control, determines what type of use will be made and where the use will be located. Based upon Professor Siegan's extensive studies of Houston, the only major nonzoned city in the United States, it appears that private decisionmakers, motivated by market forces, will make type and location decisions quite rationally. Indeed, Siegan's work tends to confirm what one might have suspected: the separation induced by zoning merely mirrors market choices. ${ }^{243}$ In this regard, heavy industry tends to locate near water and transportation resources because they are essential to its productive capacity, not because the zoning map has placed that location within the industrial classification.244

This is not meant to suggest that private decisions will always result in the "correct" choice or location of use. Imperfect knowledge or incentives may result in harmful externalities if land use decisions are made on a totally laissez faire basis. ${ }^{245}$ Harmful ex-

242 See, e.g., Zoning Ordinance of Fredertck County, Maryland $\$ 40-23$ (d)(3) (adopted 1964), reprinted in Hanke, supra note 238, at 31-34.

243 See B. SIEGAN, supra note 20 , at 75.

244 If the zoning map fails to correspond with market factors, one of two responses can be expected: if the cost of amending the community's public controls is perceived by developers as less than the cost of locating at other suitably zoned property in another community, the amendment will be pursued; if the cost of amendment exceeds the cost of relocation, relocation will be pursued. Either way, economic resources have not been maximized, because public control has siphoned resources from productive to adaptive behavior.

245 Economists refer to this as the divergence between social and private cost. These costs may diverge "when firms use resources they do not regard as scarce, when the best alternative use of a resource is not the same for a firm and for society, and when there is no market by which the firm can be reimbursed for 
ternalities would be most likely to surface where land is not clearly suitable for any particular use-that is, where land is equally suitable for any one or more of a number of uses. This possibility, however, does not justify highly-collectivized public control. ${ }^{246}$

The alternative system recognizes that some private decisions may result in harmful externalities, and that some public control may therefore be justified. It must, however, be carefully structured to protect individual liberty and to create greater economic efficiency by minimizing needless prevention and administrative costs.

The LUI system meets these requirements. What constitutes a harmful externality is largely defined by a community's conception of normalcy. The alternative system assumes that the community will translate its normalcy standard into the LUI rating schedules. ${ }^{247}$ Because normalcy standards may change over time, as community demographics change or housing and employment needs are fulfilled, the alternative system provides for the revision of the LUI rating schedule periodically.

\section{(iv) Landowner Freedom and Influences Thereon}

Beyond the initial collectivized statement of normalcy (in the form of an overall limit on density), the alternative system favors individual freedom and less collectivized methods of control. For example, the individual landowner selects the type and location of use. In addition, the landowner determines, in reference to market demand, unit size and building and site design. This freedom opens up possibilities for architectural competition and supplies flexibility to meet changing consumer preferences for units of different sizes.

benefits a different policy might yield." R. LIPSEY \& P. STEINER, Economas 220 (2d ed. 1969).

${ }^{246}$ Highly collectivized public control also may fail to maximize economic resources. This is especially true when the public control is premised upon rigid zone segregation and the unrealistic desire to eliminate every conceivable harmfu] externality, a desire which disregards the basic economic principle of diminishing returns. Moreover, a highly collectivized public control is antithetical to individual freedom and the concept of property which historically has been used to uphold personal liberty. See generally B. ACKErman, supra note 40; A. JonEs, LnFE, Limerty and Property: A Study of Conflict and a Measurement of ConFuJCtING Rights (1964); Glennon, Constitutional Liberty and Property, $51 \mathrm{~S}$. Cax. L. REv. 355 (1978); Henely, Property Rights and First Amendment Rights: Balance and Conflict, 62 A.B.A.J. 77 (1976); Horwitz, The Transformation in the Conception of Property in American Law, 1780-1860, 40 U. CFr. L. REv. 248 (1973); Powell, The Relationship Between Property Rights and Civil Rights, 15 Hastings L.J. I35 (1963); Stone, Law, Property, and Liberty: A Polemic That Fails, 42 AM. J. ORtzopsych. 627 (1972).

- 247 These schedules will express the community norms as to desired density and rate of growth of the community. The community's conception of normalcy will also enter into adjudications of nuisance suits between neighboring landowners. See supra notes 200-02 and accompanying text. 
Overarching existing market forces are three other major influences on a landowner's "free" choice of use, location, and design. In their order of increasing collectivity, the three major influences are: nuisance law, development contracts, and the public control over public improvements. The general deterrence of common law nuisance standards has already been discussed in reference to neighbor participation. ${ }^{248}$ Public control over public improvements will be considered later in conjunction with the unearned increment/ revenue device that will be used to fund public improvements. 249 Thus, our next concern will focus on the nature, influence, and constitutionality of development contracts.

\section{Public Improvement and Intensity Modification Contracts}

\section{a. Judicial Hostility to Bargaining Under the Existing System}

Although private-public bargaining has always been an implicit part of the land use process, ${ }^{250}$ it has been treated with some distaste. ${ }^{251}$ This dislike of bargaining can be traced to the fear that

248 See supra notes 200-02 and accompanying text.

249 See infra notes $304-47$ and accompanying text.

250 One commentator has remarked:

[M] any jurisdictions use techniques which make development "as of right" a rare event. Almost every development comes under the specific review and approval of the local agency. We already have, in effect, an ad hoc development-permission system. This de facto permit system provides "the discrete institutional acts onto which a system of selling development permission can be grafted." Furthermore, ... in "exchange" for these permits, government is now imposing substantial exactions, fees in lieu thereof and taxes, suggesting that we may already be selling development permission.

Glickfeld, Sale of Development Permission: Zoning on the Auction Block, in WINDFAILS FOR WIPEOUTS 376, 377 (D. Hagman \& D. Misczynski eds. 1978) (footnotes omitted) (quoting Wexler, Betterment Recovery: A Financial Proposal for Sounder Land Use Planning, 3 YALE REv. L. \& Soc. AcTron 192 (1973)). In this regard, the real debate is no longer whether land use decisions should be the subject of bargaining, but whether the bargaining should go on overtly or under the guise of mechanisms that appear to preserve the self-administering nature of the zoning ordinance. For a proposal to sell zoning overtly, see Clawson, Why Not Sell Zoning and Rezoning? (legally, that is), CRY CAL., Winter 1966-67, at 9.

251 The English have been more adroit in developing bargaining mechanisms that allow public and private parties to enter into an agreement with respect to the use and development of land, and that often contain other provisions requiring the private party to confer some benefit upon either the public authority or the community-at-large. See English Town and Country Planning Act, 1971, ch. 78, 52(1); Grant, Developers' Contributions and Planning Gains: Ethics and Legalities, $1978 \mathrm{~J}$. PLAN. \& ENvTL. L. 8; JoweL, The Limits of Law in Urban Planning, 30 Cunzent Legal Probs. 63 (1977).

California has recently passed a statute governing development agreements, CAx. Gov't CODE $\$ 65864-65869.5$ (West Supp. 1980), which is at least partially intended as a means for exacting infrastructure and other public improvements from a private developer which might, under the conventional zoning and subdivision control, be impossible to obtain. For a discussion of the California devel- 
encouraging the practice would heighten the possibility of corruption, thereby adding credence to the commonly held belief that a favorable zoning decision results more from who you know than the merits of a given proposal.

Judicial wariness of bargaining under the existing system has surfaced most frequently in the context of agreements that accompany zone amendments. Courts may invalidate an amendment by denominating the practice as impermissible contract zoning. ${ }^{262}$ In this regard, some courts have held that contract zoning is invalid per se on the grounds that it contracts away the police power, lacks uniformity, constitutes spot zoning, or violates a community's comprehensive plan. ${ }^{253}$ Other courts find this categorical condemnation to be unwarranted, suggesting instead that contract zoning be reviewed for these infirmities like any other rezoning petition. ${ }^{254}$ Of course, when there is clear evidence that the rezoning was "bought," it will be struck down as an abuse of the police power in derogation of the existing enabling legislation. ${ }^{285}$

opment agreement, see Holliman, Development Agreements and Vested Rights in California, 13 URB. LAw. 44 (1981).

It has been noted:

An auction or negotiated sale of development permission is unlikely to be acceptable in the U.S. in the near future. This is due to the combination of ... high transition costs, the problems of combining a revenue-raising device and a regulatory device into one, the problems of valuation, the potential special problems of inequity between large and small developers, poor and rich cities, and, finally, problems of planning and quality control. However, perhaps the biggest constraint to acceptance of such a system is the change in philosophy which it requires. For as much as one can demonstrate how similar sale of development permission is to current practice, it is still different and somewhat repugnant philosophically, especially to planners and courts.

Glickfeld, supra note 250, at 393.

252 See generally Note, Contract and Conditional Zoning: A Tool for Zoning Flexibility, 23 Hastivgs L.J. 825 (1972).

253 See, e.g., Hartnett v. Austin, 93 So. 2d 86 (Fla. 1956) (en banc); Baylis v. City of Baltimore, 219 Md. 164, 148 A.2d 429 (1959); Houston Petroleum. Co. v. Automotive Products Credit Ass'n, 9 N.J. 122, 87 A.2d 319 (1952).

254 See, e.g., Cross v. Hall County, 238 Ga. 709, 235 S.E.2d 379 (1977). Even in a per se jurisdiction, a court will sometimes characterize the agreement as something other than contract zoning and examine it under a less severe standard. See, e.g., Scrutton v. County of Sacramento, 275 Cal. App. $2 \mathrm{~d} \mathrm{412,79}$ Cal. Rptr. 872 (1969) (conditional zoning imposed for benefit of neighboring community is valid); Sylvania Electric Products, Inc. v. City of Newton, 344 Mass. 428, 183 N.E.2d 118 (1962) ("voluntary" adoption of restrictions by landowner induced "willingness" of city to amend zoning ordinance); State ex rel. Zupancic v. Schimenz, 46 Wis. 2d 22, 174 N.W.2d 533 (1970) (contract between homeowners and developer, to which city is a third party beneficiary, is valid).

255 See Hedrich v. Village of Niles, 112 11. App. 2d 68, 250 N.E.2d 791 (1969) (developer, in exchange for a rezoning, optioned land for a golf course, found a bond purchaser, and made certain donations to the government); see also. 
In contrast, a number of courts have been more sympathetic to zoning-related bargains. These courts use the more favorable term "conditional zoning" to describe the transaction. ${ }^{256}$ It is often difficult to discern what accounts for the more favorable treatment accorded the bargained-for elements by these courts. It is sometimes stated that conditional zoning is valid because under such zoning only the landowner is bound, whereas under contract zoning both the community and landowner are subject to an agreement. This statement, however, is more conclusory than analytical. ${ }^{257}$ Nevertheless, the existence of an agreement, if it is a contract, may bind the legislature only to approve the initial zoning amendment; it may not bind the legislature not to change its mind, at least until certain other events occur such as substantial landowner reliance in good faith upon a valid building permit ${ }^{258}$ or binding preliminary site plan approval..$^{259}$

In part, the greater acceptability of conditional zoning may result from the express or implied authority of enabling legislation. ${ }^{200}$ In other cases, however, the difference in treatment appears more substantive insofar as the bargained-for element is upheld because it is directly related to the fulfillment of public needs that will be generated by the rezoning. ${ }^{201}$ For example, where a large

Andres v. Village of Flossmoor, 15 III. App. 3d 655, 304 N.E.2d 700 (1973) (condition on rezoning requiring developer to pay $\$ 1000$ per building for general village purposes held invalid).

256 See, e.g., Sylvania Electric Products, Inc. v. City of Newton, 344 Mass. 428, 183 N.E.2d 118 (1962); Church v. Town of Islip, 8 N.Y.2d 254, 168 N.E.2d 680, 203 N.Y.S.2d 866 (1960).

257 See M. Meshenberg, The Admintstration of Frexdrde Zoning TechNrQues 36 (American Society of Planning Officials, Planning Advisory Service Report No. 318, 1975).

258 See, e.g., Andgar Assoc., Inc. v. Board of Zoning Appeals, 30 A.D.2d 672, 291 N.Y.S.2d 991 (1968).

259 See, e.g., N.J. STAt. ANN. $\$ 40: 55 \mathrm{D}-49$ (West Supp. 1981). But see supra note 133 (citing sources). See generally Krasnowiecki, Abolish Zoning, 31 SYracuse L. REv. 719, 738 (1980).

260 See, e.g., R.I. Gen. Laws $\$ 45-24-4.1$ (1980), which provides:

[T] he town or city council may in approving a zone change limit such change to one (1) of the permitted uses in the zone to which the subject land is rezoned, and impose such limitations and conditions upon the use of land as it deems necessary. The responsible town or city official shall cause the limitations and conditions so imposed to be clearly noted on the zoning map.

This provision was upheld in Sweetman v. Town of Cumberland, 117 R.I. 134, 364 A.2d 1277 (1976).

201 In Scrutton v. County of Sacramento, 275 Cal. App. $2 d 412,79$ Cal. Rptr. 872 (1969), the California Court of Appeal stated:

[C]onditions imposed on the grant of land use applications are valid if reasonably conceived to fulfill public needs emanating from the landowner's proposed use. 
shopping center project requires that an arterial road be redesigned, widened, or signaled, such burdens appropriately may be placed on the developer rather than the public at large.

\section{b. Bargained-For Land Use Control Under the Alternative System}

The alternative system involves bargaining at two junctures: first, the public improvements to be provided by the developer will be incorporated into a Public Improvement Contract; second, an increase or decrease from the LUI selected by the landowner can only be accomplished pursuant to an Intensity Modification Contract. ${ }^{202}$

For the most part, the arguments made against contract zoning seem inapposite to the contract devices of the alternative system. Because zoning itself has been eliminated, neither contract can constitute spot zoning. Similarly, because the comprehensive planning requirement found in existing enabling legislation will not be incorporated into the enabling legislation for the alternative system, this objection also becomes irrelevant.

\section{(i) Corrupt Behavior}

The bargaining envisioned under the alternative system should not encourage corrupt behavior. The alternative system obligates the developer to provide all public improvements up to the objectively determined value of the unearned increment, ${ }^{263}$ and any part of the unearned increment not used for public improvement is retained by the community. Thus, the landowner has little reason to "bribe" members of the LUCA staff for favorable treatment. Effectively, the Public Improvement Contract merely confirms the landowner's statutory obligation and translates that obligation into

The California decisions illustrate two kinds of need: the community's protection against potentially deleterious effects of the landowner's proposal ... and the community's need for facilities to meet public service demands created by the proposal .... While decisions invalidating the exaction rely upon theories of constitutional invasion, their springboard is the lack of relationship between the exaction and the proposed use ....

Id. at 421-22, 79 Cal. Rptr. at 879 (citations omitted).

262 See supra text accompanying notes $138-43$.

203 Of course, it is possible that the cost of the public improvements required will exceed the value of the unearned increment. In that event, the community would fund the excess public improvement cost from the general property tax, unless it could demonstrate that the excess was due to improvements historically financed by special assessment. This should promote historical equity among landowners. See infra note 310 . In addition, placing an absolute limitation on the developer's obligation provides certainty and encourages the community to be reasonable, both in formulating an LUI schedule and in making public improvement demands. 
the specific public improvements required with respect to the landowner's project. Moreover, because the unearned increment is determined separately and in advance of the Public Improvement Contract, ${ }^{284}$ it is unlikely that any corrupt motivations of either the landowner or the LUCA staff would infect the valuation of the unearned increment or the extent of the landowner's public improvement obligation.

Intensity Modification Contracts, as the analogue to the amendment or variance device under the existing system, may provide an opportunity for corrupt behavior. In most cases, however, the landowner initially will have selected the LUI rating most advantageous to his project and will not need any modification. If LUCA initiates the negotiations, a corrupt official could offer to reduce the landowner's public improvement obligation in exchange for nominal control over building design and a personal "kickback." To this extent, the alternative system, like any system that provides for official discretion, is subject to possible corruption. Eliminating the discretion will substantially eliminate the opportunity for corrupt behavior, but will also eliminate the system's flexibility.

The alternative system has limited the chances of corrupt activity, not by reducing flexibility, but by giving the flexibility to the landowner. Use, location, and design are now within the landowner's-not a government official's-discretion. Some official discretion does remain in the negotiation of Public Improvement and Intensity Modification Contracts. Theoretically, this discretion also could be eliminated either by making the development process totally laissez faire or by mandating in advance public improvement requirements for all projects and providing no mechanism for modification of an intensity level once it has been selected by a landowner. Neither of these choices is acceptable. If neighbor participation is to be reduced, some mechanism for ensuring that harmful externalities are generally prevented-before they become a nuisance or endanger health and safety-must exist. Public control of public improvements is that preventive device. Preestablished requirements for public improvements would be unaccepta-

264 The amount available for public improvement from the developer is a function of the land use intensity rating voluntarily chosen by the developer. The LUI rating is chosen in advance of any public determination of the public improvements required by the developer's project. Thus, unlike the existing system in which public officials may require dedications and exactions as a condition precedent to the desired rezoning, the alternative system immunizes the zoning (intensity) decision from public abuse of discretion by making it a totally private decision. Moreover, because the total unearned increment is paid to the community whether it is spent on public improvement or not, public officials should have no incentive to increase the public improvement expense arbitrarily. 
ble, and very likely inefficient, by imposing either too much or too little control on any given project. ${ }^{265}$

Whether or not an intensity modification device must be part of the alternative system is a closer question. One might want to impress upon the local legislative body the significance of the intensity schedules by not providing for changes except at regular intervals. Because of the flexibility afforded to the landowner by the alternative system, few landowners would likely object to the omission of the intensity modification device. Omission of the device, however, effectively would eliminate any possibility of ongoing public control over private improvements. Such an omission would stand in stark contrast to the increasing level of public control under the existing system ${ }^{268}$ and would eliminate flexibility on LUCA's part to deal with the special public needs that a particular project might generate. Moreover, the omission arguably is unjustified on more general policy grounds. Although this Article has demonstrated that prestated public controls tend to be unfair, inefficient, and inflexible, there is some reason to believe, based upon the PUD experience under the existing system, that sensitive public input or control of individual projects would be valuable. Because the public control contemplated by the alternative system could only occur pursuant to a bargained-for contract with the landowner, the chances of public control being wielded arbitrarily or insensitively are remote. In addition, the Intensity Modification Contract affords public decisionmakers a method of directly influencing private development without public purchase of the fee or other interest.

For all of the above reasons, both contract devices are incorporated into the alternative system, notwithstanding the fact that the discretion inherent in contract negotiation may be abused by an improperly motivated official or landowner. An attempt has been made to limit the number of opportunities for corrupt behavior by requiring that both contracts be made matters of public record. Beyond this, it is hoped that LUCA's internal monitoring and

265 For a discussion of specification standards, see supra note 71 .

266 The increasing level of public control is exemplified not only by the increased number of specialized land use or environmental regulations, but also by the type of regulation. The increased use of special exceptions, floating zones, conditional zoning, and site plan review all illustrate the trend toward particularized land use restrictions. The site plan provisions of the existing system generally require a developer to illustrate the proposed layout of buildings and open space, including parking areas, and the provisions for access to and from the public street system. "[M]any zoning ordinances require site plan reviews as a prerequisite to most forms of new land development except the construction of one- or two-family houses on single lots." D. MANDELKER \& R. ConnInGhaM, supta. note 22 , at 738 . 
management control, together with the criminal process, would adequately deter corruption.

\section{(ii) Improper Contracting Away of the Police Power}

Perhaps the most serious objection to contractual land use agreements is that they constitute the improper contracting away of the police power. This objection concerns the limitations placed on a state's exercise of its police power by the federal contract clause prohibiting the impairment of obligations, ${ }^{267}$ or what has become known as the reserved power doctrine. ${ }^{288}$

Throughout the nineteenth century, the Supreme Court utilized the contract clause to invalidate legislation that impaired private property rights. ${ }^{269}$ The contract clause was used to restrict a state's ability to modify or repeal public, as well as private, contracts. Beginning with the term of Chief Justice Taney, however, the Court began narrowing the applicability of the clause. With reference to public obligations in Charles River Bridge v. Warren Bridge, ${ }^{270}$ for example, the Court refused to find that the public charter of the Charles River Bridge Company was impaired by a later charter to the Warren Bridge Company. Effectively, the Court was able to avoid finding an impairment by narrowly construing the first charter as nonexclusive and by strictly construing the public contract in favor of the government's freedom to act. Similarly, it was the Taney Court that first enunciated the reserved power principlethat certain powers, such as the police power or the power of eminent domain, could not be made the subject of contract. The Court

267 U.S. CONST. art. I, $\S 10, \mathrm{cl} .1$ provides in relevant part: "No State shall ... pass any ... Law impairing the Obligation of Contracts ...."

268 The reserved power doctrine can be traced to a decision of the New York Supreme Court in 1826. Corporation of the Brick Presbyterian Church v. Mayor of New York, 5 Cow. 538 (N.Y. Sup. Ct. 1826). In Brick Presbyterian, the plaintiffs had entered into a lease with the city in 1766 providing that certain property could be used as a cemetery. Subsequently in 1823, the city passed an ordinance probibiting the use of the premises as a cemetery, and the plaintiff brought suit alleging a breach of the covenant of quiet enjoyment under the lease. In finding for the city, the court stated that the legislative body had no authority to enter into a contract "which should control or embarrass their legislative powers and duties." Id. 540. The principle enunciated in Brick Presbyterian became known as the reserved power doctrine when it was adopted by the United States Supreme Court in West River Bridge Co. v. Dix, 47 U.S. (6 How.) 507 (1848), in which the court found a legislative promise in a corporate charter not to exercise the power of eminent domain to be unenforceable because the legislature never had the power to convey away the power of eminent domain.

269 See J. Nowak, R. Rotunda \& J. Young, supra note 80 , at 424 . For an insightful discussion of the importance of the contract clause, see B. SIEGAN, Economic Liberties aNd the Constitution (1980).

27036 U.S. ( 11 Pet.) 420 (1837). 
reiterated this opinion thirty years later in Stone $v$. Mississippi. ${ }^{271}$ That decision upheld the state repeal of a previously granted public charter to establish a lottery business with the terse statement that "the legislature cannot bargain away the police power of a State." 272 Ultimately in 1965, the Supreme Court upheld legislation which abrogated a state's obligation under certain land contracts, simply noting that the land purchaser's rights or expectations under the contract were matters left unprotected by the Constitution..$^{273}$

In the context of a state exercise of police powers affecting private contracts, the Court in Home Building \& Loan Ass'n v. Blaisdell, 274 fashioned a reasonableness analysis, focusing on "whether the legislation is addressed to a legitimate end and the measures taken are reasonable and appropriate to that end." 275 The Blaisdell Court upheld a Minnesota law, enacted during the depression, which gave state courts the authority to extend the redemption period after a foreclosure sale. In light of the national economic emergency and the fact that the legislation protected the residual value of the mortgagee's claim, the Court found the law and the resulting contractual impairment to be reasonably related to a valid public purpose. Although Blaisdell can be seen as part of the Supreme Court's narrowing of the contract clause generally, its private contract context must be borne in mind. Decisions contemporaneous with Blaisdell, ${ }^{276}$ as well as the Court's recent treatment of the contract clause, reveal that the absence of the state's self-interest invites less judicial scrutiny of state legislation.

With legislative impairments of both public and private contracts being readily sustained, it certainly seemed as if the contract clause retained little, if any, viability. The state could always defend itself against an impairment claim by asserting either (1) that the contract was itself invalid as an improper delegation of the police power or (2) that the impairment, even assuming the contract's validity, was reasonable and rationally related to a legitimate state interest. Under the alternative system, these defenses might be urged upon a state by neighbors seeking to intervene in the

271101 U.S. 814 (1880).

272 Id. 817.

273 City of El Paso v. Simmons, 379 U.S. 497, 509 (1965).

274290 U.S. 398 (1934).

$2751 d .438$.

276 See W.B. Worthen Co. v. Kavanaugh, 295 U.S. 56 (1935) (statutes diminishing the remedies available on municipal bonds held invalid under contract clause); W.B. Worthen Co. v. Thomas, 292 U.S. 426 (1934) (statute exempting insurance funds from judicial process held invalid under contract clause). 
policy application associated with Public Improvement and Intensity Modification Contracts.

At least that was the situation when the Court decided United States Trust Co. v. New Jersey ${ }^{277}$ in 1977. In U.S. Trust, the contract consisted of a covenant between the States of New York and New Jersey and bondholders of the Port Authority of New York and New Jersey which restricted the use of Port Authority revenue. The New Jersey and New York legislatures repealed the covenant in order to subsidize a failing metropolitan commuter rail system. The Court invalidated the repeal as an unconstitutional impairment of contract.

The Court did not ignore the reserved power doctrine in U.S. Trust; however, the Court refused to be as categorical as its earlier opinions seemed to be. Specifically, the Court appears to state that a contract is not invalid $a b$ initio merely because its subject is that of the police power. ${ }^{278}$ Rather, the relevant inquiry becomes whether the agreement results in the contracting away of an essential attribute of sovereignty.

Two elements of the U.S. Trust decision require that any analysis of the decision be tentative. As might be expected, the Court left for another day the determination of what attributes of sovereignty are essential. Thus, if it turns out that the police power is always essential and the taxing or spending powers are not; the Court's language merely disguises, but does not alter, the previous formalism. Equally ambiguous is the fact that the Court's entire discussion of the reserved power question as it relates to the police power was dicta insofar as the dispute at issue presented an exercise of the spending power, ${ }^{279}$ which has long been held to be a permissible subject of contract. ${ }^{280}$

277431 U.S. I (1977).

278 Speaking for the Court in U.S. Trust, Justice Blackmun states:

In deciding whether a State's contract was invalid $a b$ initio under the reserved-powers doctrine, earlier decisions relied on distinctions among the various powers of the State. Thus, the police power and the power of eminent domain were among those that could not be "contracted away," but the State could bind itself in the future exercise of the taxing and spending powers. Such formalistic distinctions perhaps cannot be dispositive, but they contain an important element of truth.

Id. 23-24 (footnote omitted).

279 In the words of the Court, "[t] and thus as a threshold matter may not be said automatically to fall within the reserved powers that cannot be contracted away." Id. 24-25 (footnote omitted).

280 New Jersey v. Wilson, II U.S. (7 Cranch) 164 (1812); see also W.B. Worthen Co. v. Kavanaugh, 295 U.S. 56 (1935); Louisiana v. Pilsbury, 105 U.S. 278 (1882). 
Arguably, U.S. Trust should be read as applying to the police power. This should be the case if for no other reason than to carry out the Court's desire to eliminate the formalism that the Court implied may have been dispositive in some of the Court's earlier decisions. Formalism should be avoided because, in an appropriate case, either the spending or police power could constitute an essential attribute of sovereignty. For example, in the U.S. Trust case, the ability or inability of the state to apply Port Authority revenue to the deficit-ridden rail system certainly had great bearing on the ability of the state to solve the area's mass transit problems. To obscure that fact by categorizing the contract as being financial or police power in nature seems highly artificial and detrimental to a clear determination of what is, in fact, essential to sovereignty. Thus, it can be argued that no classification of state power need be undertaken and that essential attributes of sovereignty are adequately preserved by the test the Court applied to determine when the state should be allowed to impair a contract.

The test enunciated by the Court in U.S. Trust preserves essential attributes of sovereignty not by invalidating contracts with respect to certain state powers, but rather by allowing such contracts, subject to impairment when reasonable and necessary. ${ }^{281}$ It is suggested here that adding the requirement that impairments be not only reasonable, as earlier established under Blaisdell, but also necessary ("reasonableness-plus") is the device chosen by the Court to avoid formalistic distinctions between state powers. The Court's opinion provides little guidance on how deferential the judiciary should be to the legislative judgment under the reasonableness-plus standard. Nevertheless, the opinion does suggest that "complete deference to a legislative assessment of reasonableness" is inappropriate, especially when the impairment affects a public contract and "the State's self-interest is at stake." 282

Based upon this analysis, a court should require that an impairment meet the reasonableness-plus standard whenever a state seeks

281 The Court in U.S. Trust states: "We can only sustain the repeal of the 1962 covenant if the impairment was both reasonable and necessary to serve the admittedly important purposes claimed by the State." 431 U.S. at 29. Whether this is the test the court will apply to all governmental powers, or just the state's financial powers, is left somewhat unclear by the Court's opinion. See supra note 278 and accompanying text.

282431 U.S. at 26.

The Court does go on to discuss the reasonableness of the legislative repeal of the covenant "in light of the surrounding circumstances." Id. 31. That discussion focuses on the foreseeability of the need for improved mass transit services at the time that the original covenant was entered into, id. $31-32$; see id. 32 (Burger, C.J., concurring), so that foreseeability is at least one factor to be considered when determining the reasonableness of a legislative action. 
to modify or repeal its own obligations, ${ }^{283}$ regardless of the powers to which they relate. That the heightened judicial scrutiny of the reasonableness-plus standard is intended to extend to all state obligations and all state powers is revealed by the Court's discussion of how the necessity element of that standard may be fulfilled. Specifically, the state must show that the impairment is "necessary" to serve an important public purpose or to secure an essential attribute of sovereignty. Thus, the purpose or value of the reasonablenessplus standard enunciated in U.S. Trust to private parties is twofold: it provides greater assurance to those contracting with the state by defining the circumstances when an impairment is justified and it enlarges the scope of permissible state obligations to include police power subjects. 284

In applying the reasonableness-plus standard, the Court will scrutinize the legislative action to determine whether it is the least intrusive alternative. In U.S. Trust, the Court determined that less drastic alternatives to the repeal of the bond covenant would have advanced the state's interest in "[m]ass transportation, energy conservation, and environmental protection." 285 Moreover, the Court distinguished the repeal of the covenant in U.S. Trust from previous decisions of the Court in which the surrounding circumstances suggested that the state did not foresee certain events at the time it entered into the contract. ${ }^{286}$ In this regard, the Court observed that the need for mass transportation was well-known at the time the rcovenant was entered into by the state and that "[i]ndeed, the covenant was specifically intended to protect the pledged revenues...

283 As the Court later commented in Allied Structural Steel Co. v. Spannaus, 438 U.S. 234 (1978) (invalidating a state pension reform law that impaired the pre-existing pension plan obligations of a private employer): "[I]mpairments of a State's own contracts would face more stringent examination under the Contract Clause than would laws regulating contractual relationships between private parties ...." Id. $244 \mathrm{n} .15$ (citation omitted). When legislation impairs the rights and responsibilities of two private contracting parties, the Court analyzes the impairment from the standpoint of reasonableness.

284 Of course, the ambiguity surrounding the Court's disavowal of the formalistic categorization of state powers tempers this conclusion. If the Court continues the formalism of earlier decisions, then presumably the necessity element relates - only to the state's burden in justifying the impairment.

285431 U.S. at 28-30.

288 The Court stated:

[I]n the instant case the need for mass transportation in the New York metropolitan area was not a new development, and the likelihood that publicly owned commuter railroads would produce substantial deficits was well known. As early as 1922, over a half century ago, there were pressures to involve the Port Authority in mass transit. It was with full knowledge of these concerns that the 1962 covenant was adopted.

.Id. 31-32. 
against the possibility that such concerns would lead the Port $\mathrm{Au}$ thority into greater involvement in deficit mass transit." ${ }^{287}$

Significantly, the Court has not confined the U.S. Trust analysis to public contracts. In Allied Structural Steel Co. v. Spannaus, 288 decided during the Term following U.S. Trust, the Court invalidated a Minnesota statute which required employers of more than 100 employees, at least one of whom lived in Minnesota, to pay a "pension funding charge" if they provided certain pension benefits to their employees, and if they either closed an office or plant in Minnesota or discontinued their pension plan. The charge was in an amount sufficient to provide full pensions for all employees cut off from pension benefits who had accumulated ten years of service with the company; periods prior to the passage of the act were to be counted towards the ten year period. The Court found an impairment of the contract between employer and employee and, applying the U.S. Trust analysis, held it to violate the contract clause.

Spannaus is noteworthy because it seems to blur any distinction between public and private contracts for purposes of contract clause analysis. The absence of the state's self-interest may ultimately lead the court to defer to legislative judgment with regard to the issues of reasonableness and necessity when the state seeks to impair a private-rather than a public-contract; ${ }^{289}$ nevertheless, Spannaus suggests that the regulatory powers of the state will be limited by the contract clause whether or not a financial obligation of the state is involved. In the Court's words, "[i] $\mathrm{f}$ the Contract Clause is to retain any meaning at all, . . . it must be understood to impose some limits upon the power of a State to abridge existing contractual relationships, even in the exercise of its otherwise legitimate police power. ${ }^{290}$ Thus, recent Supreme Court decisions appear to lend support to the contractual regulation implicit in the alternative system.

The contractual basis of the alternative system also finds support in state case law. For example, the contract involved in Sonoma County Organization of Public Employees $v$. County of Sonoma 201 was a wage agreement between various cities and counties and a labor organization representing public employees. The alleged im. pairment occurred when the state legislature, as part of its distribu-

287 Id. 32.

288438 U.S. 234 ( 1978 ).

289 This argument was made by Justice Brennan in dissent. Id. 251.

290 Id. 242 (emphasis in original).

20123 Cal. 3d 296, 591 P.2d 1, 152 Cal. Rptr. 903 (1979) (en banc). 
tion of state surplus funds to local government bodies, invalidated any wage agreement that called for a cost of living increase in excess .of that allowed for state employees. While admittedly the initial -wage agreement may be characterized as an exercise of the spending -power, the California Supreme Court engaged in none of the formalism implicitly disfavored by the U.S. Supreme Court in U.S. Trust. Instead, the California court, expressly looking to U.S. Trust for guidance, first determined the severity of the impairment; finding it severe, the court then considered whether the impairment was reasonable and necessary to an important public purpose. Recognizing that complete deference to the legislative assessment of reasonableness and necessity was not appropriate when the government's self-interest was at stake, the court determined that the fiscal conditions alleged to justify the impairment had been mitigated by other legislation; hence, the contract impairment was impermissible under the contract clause.

(iii) The Reserved Power Doctrine and the Existing System

Very few cases specifically in the land use context contain any significant analysis of the tension between the contract clause and the reserved power doctrine. As noted earlier, courts unfavorable to contract zoning tend to focus on the statutory requirements of uniformity and the potential for official abuse presented by departure from uniform application. A few decisions seemingly add as an afterthought that a public body cannot surrender its legislative functions; ${ }^{292}$ these decisions add little in the way of substantive analysis. Similarly, decisions approving contract or conditional zoning tend to be equally unenlightening. ${ }^{293}$

Nonetheless, the land use area is not without precedent upholding the ability of a government entity to enter into contracts with private parties that to some degree restrict the government's ability to exercise its police power in the future. For example, in Morrison Homes Corp. v. City of Pleasanton, ${ }^{294}$ the Cailfornia Court of Appeal upheld a number of annexation agreements under which the developer agreed to pay an annexation fee and make certain site improvements in exchange for the city's promise to annex, zone, and

292 See, e.g., Harnett v. Austin, 93 So. $2 \mathrm{~d}$ 86, 89 (Fla. 1956) (en banc); Houston Petroleum Co. v. Automative Products Credit Ass'n, 9 N.J. 122, 130, 87 A.2d 319, 322 (1952).

293 See, e.g., Church v. Town of Islip, 8 N.Y.2d 254, 168 N.E.2d 680, 203 N.Y.S.2d 866 (1960); State ex rel. Zupancic v. Schimenz, 46 Wis. 2d 22, 174 N.W.2d 533 (1970).

29458 Cal. App. 3d 724, 130 Cal. Rptr. 196 (1976). 
provide adequate capacity in the city's sewage facility. All went well until a regional water quality board issued an order preventing further sewer hook-ups. When the developer brought an action for specific performance and damages, the city argued that it was not liable because annexation was a police power function which could not be "contracted away." The court disagreed, finding that the agreements did not amount to a total surrender of municipal control but rather, insofar as the annexation agreements coincided with the master plan and zoning ordinance, they carried out municipal policy. Thus, the Morrison opinion recognized that a municipality can contract with reference to its police power and that such contracts are not void $a b$ initio. In addition, the opinion can be read as finding that the city's reasons for failing to honor the agreement were unreasonable and unnecessary to the carrying out of an important public purpose. With reference to this last point, Morrison can perhaps be criticized for failing to discuss adequately the possibility that public health standards might at some point justify an impairment of the agreement under the U.S. Trust standard.

Other state court decisions support the general contours of the Morrison opinion. For example, a city's contract to install subdivision improvements has been enforced against a successor city council,,95 and a city has been estopped from applying a zoning ordinance that undermines a previous guarantee of a specified density given in exchange for a land dedication. ${ }^{296}$ In still another case, a court has held a municipality to a contract that bound the municipality to cooperate with the state-created housing authority. ${ }^{297}$

The recent enactment of a California statute authorizing socalled development agreements lends credence to the belief that a government entity can contract with respect to its police power. ${ }^{298}$ The statute is an attempt to bring some certainty to the state's land development process, which has been characterized by frequent change in government regulation and a correspondingly inadequate and late judicial vesting rule. ${ }^{299}$ Recognizing that this lack of certainty has wasted economic resources and escalated the cost of hous-

295 Carruth v. City of Madera, 233 Cal. App. 2d 688, 43 Cal. Rptr. 855 (1965).

296 Mayor of Baltimore v. Crane, 277 Md. 198, 352 A.2d 786 (1976).

297 Housing Authority v. City of Los Angeles, 38 Cal. 2d 853, 243 P.2d 515 (en banc), cert. denied, 344 U.S. 836 (1952). This decision partially relies upon a state statute that authorizes cooperation between the authority and city as support for the position that the agreement was not an unauthorized attempt to contract away the police power.

298 CAL. Gov'T CoDE $\$ \$ 65864-65869.5$ (West Supp. 1980); see Holliman, supra note 251.

209 See supra notes 107-34 and accompanying text. 
ing, the development agreement mechanism ostensibly allows a private developer and a government entity to agree in advance as to such matters as permitted use, density, height, and size; such advance agreement shall govern "notwithstanding any change in any applicable general or specific plan, zoning, subdivision, or building regulation." 300 Thus, unlike the proposed alternative system which reduces the level of public control, the California statute retains extensive public control over land use, while trying to provide assurance that the nature of the control will not be altered substantially during construction. ${ }^{301}$ The fact that the California legislature passed the statute, with the concurrence of the League of California Cities, tends to indicate that both believe that contracts which restrict the future exercise of the police power are possible, at least with express statutory authority.

\section{(iv) The Reserved Power Doctrine and the Alternative System}

At last, we are in a position to speculate as to the effect of the reserved power doctrine on the alternative system. Our speculation is aided by distinguishing Public Improvement from Intensity Modification Contracts. Public Improvement Contracts should not run afoul of any conception of the reserved power doctrine. Because the Public Improvement Contract merely defines the quantity and quality of the public improvement to be constructed with public money, the contract can be characterized as an exercise of the spending power. Thus, if past formalism survives U.S. Trust, contrary to the analysis suggested earlier, the Public Improvement Contract should survive an initial determination of validity. Whether or not LUCA or the local legislative body subsequently could modify or repeal a Public Improvement Contract would depend upon the impairment's reasonableness and necessity. While there may be cases in which necessity might justify impairment, the burden of that justification would be with the community, as it was in U.S. Trust. ${ }^{302}$

300 CAL. Gov't Code $§ 65865.4$ (West Supp. 1980).

301 Whether the development agreements authorized by the California statute will provide the needed certainty is an open question insofar as it may leave intact a battery of discretionary actions, as well as the possibility that a city, through some cooperating governmental entity or related body of regulation not subject to agreement, may frustrate the agreement's entire purpose. See Hagman, supra note 134, at 70 .

302 An argument can be made that the community's burden for justifying certain impairments of a Public Improvement Contract should be less because of the inherent nature of the alternative system. Specifically, it can be argued that asking the landowner to increase the quantity or quality of public improvements is 
Intensity Modification Contracts clearly run contrary to the formalistic application of the reserved power doctrine. The subject matter of such a contract, as its name indicates, may relate to the intensity of development and the public's role, if any, in defining: permitted uses, height, size, and overall design of the private improvements. Under the existing system, all of these matters are traditional police power concerns; hence, a court which insists on confining U.S. Trust to its spending power facts would likely find an Intensity Modification Contract to be void $a b$ initio and the state would be free to modify unilaterally any agreement entered into with a developer. This analysis would be unfortunate, not only because it would be an impediment to the alternative system, but also because it would represent the substitution of simple-minded categories for substantive analysis to determine whether a given Intensity Modification Contract preserves the essential attributes of sovereignty.

In the context of the alternative system, it is possible to argue that Intensity Modification Contracts not only preserve but also promote a community's sovereignty. Because the landowner, and not a public entity, retains discretion over substantially all land use issues, the motivation for entering into an Intensity Modification Contract is most likely to originate with LUCA. If LUCA desires public control over aspects of a particular private development, it can endeavor to obtain that control through the Intensity Modification Contract mechanism. Thus, the contract would likely increase, rather than decrease, sovereign control over the land development process.

Even if U.S. Trust is construed narrowly, the passage of the alternative system's enabling legislation should enhance the acceptability of the Intensity Modification Contract. By authorizing such contracts, the legislature is presumably indicating that the contracts

not asking him to do any more than what LUCA could have required as a maximum obligation in the first place-that is, improvement up to the value of the unearned increment. This argument is valid to the extent that a court balances the police power against the landowner burden created by the improvement as part of its determination of necessity. The premise underlying the argument, however (that a landowner is always liable for public improvement up to the value of the unearned increment even after the Public Improvement Contract is negotiated), should not be made into a general principle. Doing so would ignore the extent to which the landowner has relied upon the Public Improvement Contract in making private improvements. If the landowner has relied substantially on the originally accepted public improvement plan, the community's justification of any impairment should be more, not less, rigorous. This latter statement is entirely consistent with U.S. Trust, which suggested that a sliding scale approach be adopted. 431 U.S. at 29-31. Thus, not only is the impairment of a publiccontract more strictly reviewed than an infringement of a private contract, but also the severity of the impairment itself will dictate the level of review. 
are not inherently inconsistent with the exercise of sovereign power. Moreover, it has long been held that a state can define the extent of local governing power and even, under some circumstances, withdraw that power at will. ${ }^{303}$ In this regard, the alternative system's enabling legislation will contain a withdrawal of the preestablished, pervasive local power over land use and a substitution of the negotiated public control embodied by the Intensity Modification Contract. The alternative system represents a fundamental change in perspective from a pervasive government to one of limited control.

\section{The Unearned Increment: Its Recapture and Use for Public Improvements and General Revenue}

In any decision to purchase undeveloped land, land value will be calculated not onily in reference to the land's current use, but also with respect to any possible future use. The value of agricultural land will be the present value of the agricultural production as well as the discounted present value of the land's future developed use. Thus, the price of agricultural land is equal to the sum of the capitalized value of the current use plus the capitalized value of any future use discounted to the present. The value of any future use will depend upon the intensity of future development, the time of development, and the property's holding costs-principally interest and taxes.

The alternative system recaptures the difference between the future use value, represented by the voluntarily-selected LUI rating, and the value of the land's current agricultural/open space use. The recaptured amount is termed the unearned increment, and it will be used primarily to fund any public improvements required by the Public Improvement Contract. Any portion of the unearned increment not used by the developer for public improvements will be paid to the community as general revenue. Following current practice, public improvements will be required to be completed, or an adequate bond supplied, in advance of subdivision recordation and the sale of lots..$^{304}$ Mechanically, the payment of surplus un-

303 One treatise notes that "[t]he cases reinforcing the right of a state to alter or retract at will the terms of its agreement with a smaller governmental entity are legion." J. NowAK, R. RorundA \& J. Young, supra note 80, at 425 n.47 (citing cases).

304 See generally Green, Land Subdivision, in Prunciples and Practice of Urban Planning 443, 449-54 (W. Goodman \& E. Freund eds. 1968). For a discussion of performance bonds, see supra note 37 . It should also be noted that subdivision recordation does not mean subdivision control as it is presently constituted. The alternative system utilizes subdivision recordation as a procedural device to ensure accurate land titles, not as a substantive control. Thus, if the 
earned increment will be secured by a lien of first priority on the subject property. Payment of the surplus itself will occur over the life of the development project in accordance with a schedule incorporated into the Public Improvement Contract.

\section{a. The Property Tax and Public Improvement}

Historically, considerable public improvement was financed by means of the general property tax. ${ }^{305}$ Property tax and expenditure limitations, ${ }^{306}$ as well as competing community needs such as education, increasingly have made the property tax an inadequate source of revenue for infrastructure purposes, ${ }^{307}$ especially the infrastructure associated with a heightened housing demand. Even without statutory limits on the property tax, few communities are willing to finance the infrastructure needed for new development preceived as benefiting only "outsiders." In addition, most communities recognize that controlling the supply of new housing drives up the price of existing housing, thereby benefiting "insiders"; hence, as Professor Hagman has noted, "it would hardly be financially astute for an existing community of homeowners to use funds raised from them by property taxes ... to put in the infrastructure necessary for new development." 308 Thus, if infrastructure is to be provided at:

developer fulfills the terms of his Public Improvement Contract and does not exceed the land use intensity voluntarily selected by him, subdivision recordation is automatic.

305 See Ellickson, supra note 3 , at 465 .

306 Perhaps the best known of these limitations is Califormia's Proposition 13 , CAL. Const. art. XIIIA, $\S 1$, which limits the ad valorem tax on real property to one per cent of the full cash value of such property. California, however, has not been alone in its efforts to control property taxes. For example, long before California enacted Proposition 13, Indiana froze its property taxes at 1973 levels. IND. REv. CODE \$6-1.1-18-2 (Supp. 1980). Professor Hagman suggests that property tax limits can be traced as far back as 1870 to Rhode Island. D. HAcMAN, supra note 19 , at 867 .

307 Professor Hagman notes:

The consequences of Proposition 13 on land use and the development of land were substantial. Consider them. Since general revenues were reduced substantially, to the extent provision of infrastructure was regarded as the "fat" rather than the "bone" of governmental expenditure, eliminate provision of infrastructure from general funds [sic]. Since general obligation bonds were no longer issuable because an unlimited property tax rate to pay them could no longer be assured, infrastructure became difficult to finance by bonding. So-called limited obligation excise-tax bonds, e.g., pledging revenues from such as sales taxes, and revenue bonds, could still be used to finance some infrastructure. Interest rates likely rose because the security of such bonds was lower.

D. HAGMAN, supra note 19 , at 869 .

308 Id. 920. 
all, most communities have sought ways of placing its cost with the developer.

\section{b. Impact Fees and Construction Taxes}

Under the existing system, two principal methods exist for passing on the cost of the public improvements to developers: impact fees or exactions, and general taxes on the construction process. As mentioned earlier, no satisfactory rationale has emerged for determining when impact fees are appropriate. ${ }^{309}$ Some courts require that the particular fee or public improvement be "specifically and uniquely attributable" to the development, others demand some "rational nexus," and still others find that the fees are justified so long as the community uses the funds reasonably. All these rationales have been criticized elsewhere, ${ }^{310}$ and for present purposes, it is enough to note that they are imprecise ${ }^{311}$ and generally poor tests of the fairness of any particular exaction.

The general tax alternative under the existing system is neither precise nor fair. For this reason, courts have been reluctant to allow communities to impose a general tax on development without express statutory authority. ${ }^{312}$ Thus, a community is generally pro-

309 See supra note 34.

310 See Ellickson, supra note 3, at 450-75. Professor Ellickson has argued that the judicial rationales are deficient because they fail to address the issue of horizontal fairness among landowners. Specifically, he states that "if a municipality mixes special and general revenues in financing a service, the portion financed by general revenues should presumptively be distributed equally per dwelling unit." Id. 460 (footnote omitted).

In addition to problems of horizontal fairness among landowners, it is important to realize that new development may impose a number of different types of costs. on a community, and that courts may not treat all such costs as equally valid reasons to exact special fees. For example, much case law restricts the use of subdivision exactions as a device to exclude housing of a lower aesthetic quality than currently exists in the community. In contrast, courts are more receptive to subdivision exactions that address the congestion and fiscal costs of new development. See Blumstein, supra note 168, at 36-38; see also M. Brooks, Mandatory Dedication of Land on Fees in Liev of Land for Parks and Schools (American Society of Planning Officials, Planning Advisory Service Report No. 266, 1971); Adelstein \& Edelson, Subdivision Exactions and Congestion Externalities, 5 J. Legax. Stud. 147 (1976); Johnston, supra note 33; Note, Subdivision Land Dedication: Objectives and Objections, 27 Sran. L. Rev. 419 (1975).

311 Even the most stringent exaction requirement may be evaded in practice. See Platt \& Moloney-Merkle, Municipal Improvisation: Open Space Exactions in the Land of Pioneer Trust, 5 UrB. LAw. 706 (1973).

312 Dean McCarthy notes:

Fees are customarily exacted for the award or renewal of licenses and permits [by a local government]. While one might conceptually demonstrate that the costs of regulation are expenses of government like all others and that methods of obtaining revenues to pay government expenses constitute taxation, the power to exact license and permit fees has been considered to be within the penumbra of the police, not the 
hibited from raising revenue from fees charged for development permits. When a community has the express power to tax or levy user fees, however, courts will sustain such fees, except when the tax or user fee is confiscatory or when it contains classifications not rationally related to the carrying out of a legitimate legislative goal. ${ }^{313}$ Because taxes seldom constitute a substantial percentage of the sale price of each dwelling unit, they are rarely found to be confiscatory. Moreover, because tax classifications are presumed rational until proven otherwise, fine distinctions between residential developers and commercial builders, ${ }^{314}$ and between the construction of new dwellings and additions to existing dwellings, have been easily sustained. ${ }^{315}$ The primary danger of the general tax alternative stems from the fact that the taxing power, once granted, is construed broadly without meaningful legal constraints or limits. Recognizing that "the power to tax is the power to destroy," ${ }^{316}$

\begin{abstract}
taxing, power. As a result, such fee exactions cannot be intended to be revenue producing vehicles, and licensing for revenue must be distinguished from licensing for regulation.... [I]n order to license for revenue, the municipality must be empowered by state delegation of such taxing authority, and such regulations will be evaluated under the rubrics applicable to local taxation.
\end{abstract}

D. McCarthy, Locax Government Law 120-21 (1975). For a case in the land use area acknowledging this general principle, see Contractors \& Builders Ass'n v. City of Dunedin, 329 So. 2d 314 (Fla. 1976), cert. denied, 444 U.S. 867 (1979). See also Merrelli v. City of St. Claire Shores, 355 Mich. 575, 96 N.W.2d 144 (1959) (en banc); Strahan v. City of Aurora, 38 Ohio Misc. 37, 311 N.E.2d .876 (1973).

313 See, e.g., Westfield-Palos Verdes Co. v. City of Rancho Palos Verdes, 73 Cal. App. 3d 486, $141 \mathrm{Cal}$. Rptr. 36 (1977) (upholding an environmental excise tax of $\$ 500$ per dwelling unit); Hartman v. Aurora Sanitary Dist., 23 Ill. $2 d 109,177$ N.E.2d 214 (1961) (deferring to the legislature and upholding a $\$ 160$ charge for connection to the city's sewer line).

314 See Associated Home Builders v. City of Newark, 18 Cal. App. 3d 107, $95 \mathrm{Cal}$. Rptr. 648 (1971) (upholding a larger bedroom tax on residential development than commercial and industrial development, because the former could conceivably require greater fire and police protection).

315 The California Court of Appeal has stated:

[W] can conceive of a valid distinction between residential developers and contractors sufficient to sustain the instant [bedroom tax] ordinance against an equal protection attack. Thus, there are significant differences both in business function and in the scope of development which justify the developer-contractor classification. That is, a developer normally plans an entire subdivision and then mass produces the homes within a somewhat expensive tract. ... [T] he contractor usually custom designs homes pursuant to individual contracts with the owners. Given such distinctions, the fact that the burden of the license tax may be borne unequally among the different classifications is of no constitutional significance.

Westfield-Palos Verdes Co. v. City of Rancho Palos Verdes, 73 Cal. App. 3d 486, 496, 141 Cal. Rptr. 36, 43 (1977) (citations omitted).

316 McCulloch v. Maryland, 17 U.S. (4 Wheat) 316 (1819). 
some communities have employed the tax not to raise the revenue necessary for public improvement but to halt or substantially impede housing construction of all types. The fact that a permanent no-growth attitude may exceed the community's police power may be of little consequence when a local governing body may achieve social and economic ends by the manner in which a tax is imposed, even if such objectives might otherwise exceed the governing body's. regulatory power. ${ }^{317}$

That existing nonproperty tax methods for imposing the public improvement cost on developers may be unworkable, uncontrollable, or undemocratic does not mean that it is improper to impose such costs pursuant to a mechanism that fairly represents the benefits received. A compelling case can be made that if prior public and private activity has made a community a desirable place to live, developers should not be free to impose unexpected and uninternalized costs on a community at will. Certainly, it is unrealistic for developers to refuse to bear their own costs and then assume that a community will not adopt some antigrowth measure that will make the infrastructure cost issue academic.

The recapture of the unearned increment and its application to. public improvement under the alternative system is a workable and fair method for imposing infrastructure costs on the developer. Unlike impact fees or exactions, which are justified on the basis of vague judicial standards, the unearned increment could be objectively determined by an appraiser mutually acceptable to the community and the developer. Unlike the construction or business license taxes which have been imposed without legal limitation, the amount of unearned increment recoverable from any given landowner under the alternative system will be expressly limited to the amount determined by the appraiser. ${ }^{318}$

317 See, e.g., Andrews v. Lathrop, 132 Vt. 256, 315 A.2d 860 (1974) (upholding Vermont's land gains tax). For a discussion of land value taxation, see infra notes 322-36 and accompanying text.

318 The alternative system both simplifies and complicates land appraisal. As previously indicated, land value is a function of present and discounted future value. Future value under the existing system is difficult to assess because of the unpredictability of future uses. Nevertheless, valuation practice requires that valuebe determined in reference to all potentially available-though not merely speculative-uses. See $1 \mathrm{~L}$. Orgen, Valuation under the Law of Eminent Domatn $\$ 30$ (2d ed. 1953). Because under the alternative system appraisal is conducted at a time when the future use has been defined by the LUI selection of the landowner, future value can be determined with reference to that particular use. WhileOrgel suggests that valuing property in its "best use," rather than with respect to "all available uses," leads to the undervaluation of property, id. $\$ 30$, at 149 , his remarks are properly confined to the condemnation process where the object is the determination of a purchase price, rather than an unearned increment related to. 


\section{c. Arguments Against Unearned Increment Recapture}

Landowners may make two arguments against unearned increment recapture under the alternative system. As a matter of historical equity, landowners may point out that to the extent the infrastructure in the existing community was financed with the property tax, which they (or a predecessor in title) paid, the unearned increment recapture constitutes double taxation. ${ }^{319}$ While such an argument is historically accurate, and theoretically valid, it loses sight of the present-day reality that inflation and the general cost of money have made today's infrastructure more costly than yesterday's, and that statutory limits and political pressure have kept the property tax from keeping pace. Nevertheless, the argument has current validity to the extent the property tax is still being used to finance the capital construction of new or replacement public improvements which benefit the existing community. Clearly, there would be an inequity, as some courts have recognized with regard to school facilities, "if new construction alone were to bear the capital cost of new schools while also being charged [through property taxes] with the capital costs of schools serving other portions of the school district." 320

The alternative system proposes to eliminate this potential inequity, not by refusing to recapture the unearned increment from the developer, but by also recapturing it from landowners in the existing community. Specifically, when a landowner in the existing community is specially benefited by capital construction, that unearned increment will be recaptured by means of a special assess-

the recoupment of windfall gain for public facility purposes. Thus, part of the valuation guesswork is eliminated by the alternative system.

The alternative system, however, also complicates appraisal by removing the viability of one of the appraiser's easiest valuation techniques: comparable sales of similar property proximate to the time of valuation. Such evidence is unhelpful under the alternative system because sale prices should no longer reflect the prospective land value windfall or unearned increment which is being recaptured. While appraisers might look to sales of comparably developed property or undeveloped property prior to the implementation of the alternative system (adjusted for inflation), such evidence may be tainted by the existing system's artificial scarcity of certain use classifications. In this regard, Orgel cites numerous cases in which temporary depressions, id. $\$ 24$, periods of "boom prices," id. $\$ 25$, and certain government regulation, $i d$. $\$ 26$, have been excluded from the value determination. Nevertheless, the case law is clearly divided, and an appraiser might be well-advised to avoid the difficulty altogether by using an alternative valuation technique, such as anticipated income or business profits, $i d$. $\$ \S 155-175$, or estimated rental value, $i d$. $\$ \$ 176-187$.

319 See generally Ellickson, supra note 3, at 450-89.

320 West Park Ave., Inc. v. Township of Ocean, 48 N.J. 122, 126-27, 224 A.2d $1,4(1966)$. 
ment. In this way, the developer's property tax should be reduced -because that source of revenue will no longer bear the liability of capital construction for the existing community-and the alleged inequity of prospective double taxation will be eliminated.

The second argument a landowner may make against unearned increment recapture relates, not to its application to the cost of public improvement, but to its retention beyond that cost as a source of general revenue. Specifically, the developer may argue that such recapture will inevitably make the high cost of housing even higher and that it unjustifiably deprives the landowner of land value to which he is entitled as an incident of ownership. Whether or not housing costs will rise is a debatable proposition. To the extent that housing demand is elastic, the landowner-developer will find passing on the cost to the housing consumer to be difficult. ${ }^{321}$

This is not to suggest that the recapture cost is merely written off, at least not by the developer. Up to this point, we have been treating the original landowner and developer as having the same or related interests; however, allocating the recapture cost may cause those interests to diverge. A developer purchasing land knows his material and labor costs as well as his expected margin of profit. One can be fairly certain that to the extent the developer is unable to pass the recapture cost forward he will pass the cost backward to other participants in the construction process. If the recapture cost cannot be made up in this manner, the cost will be borne by the original landowner insofar as he will find it necessary to sell to the developer at a lower price.

321 In discussing the incidence of a land gain tax, Dean Misczynski states:

[T]he "Simply Pass It On" theory, . . . enjoys remarkable popular credibility despite almost universal denegration [sic] by tax experts. The notion is that if a landowner, houseowner, or builder must pay a gains tax, he will simply raise the price of his property by enough to cover the tax. ... There are a number of problems with this view. An initial one is, if the owner could easily sell his property at a price higher by the amount of the tax, why would he not do so even if there were no tax? Surely sellers are anxious to sell for the highest price they can get. A more sophisticated version of this theory is that if all sellers expect to be able to pass the tax on, and if they all hold out for higher prices, they will effectively shift up the short-run supply curve, raising the short-run price. This proposal raises some relatively complicated issues, but a simple critique is that if the shift in supply leads to higher housing prices, then fewer properties will be sold (unless the demand for housing is such that quantity demanded does not change at all with price, and there is considerable evidence that this is not the case). Hence, some owners will be frustrated in their effort to sell property, and will eventually drop their price.

Misczynski, The Question of Incidence, in Windfalls For WrPEOurs 112, 127-28 (D. Hagman \& D. Misczynski eds. 1978). 


\section{d. Henry George and the Land Value Tax}

Is a landowner entitled to a return of the unearned increment not necessary for public improvement (the surplus unearned increment)? A strong argument was made by nineteenth-century philosopher Henry George that a landowner has no justifiable claim to any land value, much less the surplus unearned increment. ${ }^{\mathbf{3 2 2}}$. George's. position was premised on the fact that land as a commodity is totally inelastic; hence, increasing the tax on land will not reduce its supply in a competitive market. In this regard, everything a landowner earns from the land itself-as distinguished from any improvement to the land-constitutes economic rent. The amount a landowner earns from land is a function of its location and physical features and not of individual landowner effort. Thus, any tax on such landrelated value merely recaptures value that has been generated by nature or other public and private activity of the community; value which the individual landowner did not earn and hence to which he has no entitlement.

George's theory has been heralded as a source of municipal wealth, an incentive for rational development and urban renewal, and a disincentive to land speculation. ${ }^{323}$ There is some evidence that the land value tax has the capacity to do all those things. For example, rational development may be fostered because a land value tax would be heaviest on the land in central cities with the most value, which from a planning standpoint of lowering utility extension and energy costs ought to be developed before hinterland. Similarly, the land value tax may encourage urban renewal because any new improvement would be exempt from tax and existing improvements would be well-maintained in order to generate sufficient income to pay the land value tax. Finally, land speculation may be reduced because of the dramatic increase in holding costs precipitated by the land value tax.

A pure land value tax, however, may also have its drawbacks. For example, land value assessments tend to be very crude. ${ }^{324}$ All

822 H. George, Progress aNd Poverty 358-67 (1962).

${ }^{323}$ See Hagman, The Single Tax and Land-Use Planning: Henry George Updated, 12 U.C.L.A. L. Rev. 762 (1965).

324 Professor Hagman notes:

The assessors were having ... practical difficulty with the tax. They were, of course, to assess the land at market value. But when an area was developed so that the only sales were of developed sites, the sales prices were no longer the best evidence of the actual value of the land. Moreover, the original purchase price of the site became irrelevant as evidence in a few years because of the rapid rise in values.

Id. 774 (footnote omitted). 
land situated near a particularly desirable public improvement would likely be assessed at a very high land value despite the fact that, because of limited demand, only a few parcels close to the improvement could attract a use that would justify the tax. In addition, assessing land in core areas at a high land value requires high density improvements to pay the tax. Absent any other density control, the densities generated would likely be intolerably high. Moreover, a land value tax might lower land prices to such an extent that development would inevitably replace a disproportionate amount of agricultural land.

Despite these drawbacks, variations of the land value tax have been continuously experimented with to the present day. Perhaps this experimentation continues because of George's inherently sound position that the community, rather than the landowner, has the just claim to land value. Professor Hagman's "windfall recapture/ wipeout mitigation" proposal impliedly carries forward George's ideas. ${ }^{325}$ Under Hagman's proposal, any increase in land value not caused by inflation or the owner is recaptured and, at least in part, used to mitigate wipeouts or certain decreases in land value. While using windfalls to mitigate wipeouts appears to be pure Hagman, ${ }^{226}$ the salutory by-products of recapturing the windfall land value is essentially George. Like George, Hagman cites fairness, the reduction in land speculation, and better planning-not biased by windfallers supporting plans for the wrong reasons or by potential windfallers distorting plans through bribery and other inveiglementas reasons supporting his proposal. . $^{327}$

Henry George's ideas have been of more than academic interest. Land value taxation schemes have been enacted in England, ${ }^{328}$

825 See Hagman, supra note 54.

320 The idea itself, as Professor Hagman notes, can be traced to the English Housing, Town Planning, \&c. Act, 1909, 9 Edw. 7, ch. 44, $\$ 58$, reprinted in D. Hagnear, supra note 19, at 950, which provided until the mid-1940's as follows:

Where, by the making of any town planning scheme, any property is increased in value, the responsible authority shall be entitled to recover from any person whose property is so increased in value one-half of the amount of that increase. Any person whose property is injuriously affected by the making of a town planning scheme shall be entitled to obtain compensation in respect thereof from the responsible authority.

327 Hagman, supra note 54.

328 The Finance (1909-10) Act, 1910, 10 Edw. $7 \& 1$ Geo. 5, ch. 8. The tax levied a duty of $20 \%$ on the value of land, and was collected on sale, lease in excess of 14 years, death, and periodically in the case of corporations and unincorporated associations. The administrative costs of collecting the tax far exceeded the revenue produced and the Finance Act was repealed in 1920. See R. YardLey, Land Value Taxation and Rattang 260-73 (1929). 


\section{Canada, ${ }^{329}$ New Zealand, ${ }^{330}$ and Australia. ${ }^{331}$ In this country, variations of his ideas appear in the statues of California, ${ }^{332}$}

329 Unearned Increment Tax Act, ch. 10, 2d Sess., 1913 Alta. Stat. $46.2 \mathrm{~d}$ Sess., ch. 10. The tax applied to the "increased value of ... land over and above the value thereof according to the last ... value for the purposes of this Act, excluding in all cases the cost of improvements or of development work actually made or done upon or in connection with the . . . land." Id. $\S 3$. The tax was collected on sale and was required to be paid prior to land registration. The tax was continued at various rates until its repeal in 1956. Act of Mar. 29, 1956, ch. 57, 1956 Alta. Stat. 377. In June 1974, the province of Ontario enacted the Land Speculation Tax Act which taxed certain speculative gains in land value at the rate of 50\%. Act of June 3, 1974, ch. 17, 1974 Ont. Stat. 83; see Glickfeld \& Hagman, Special Capital and Real Estate Windfalls Taxes (SCREWTS), in Windfarts For WIPEouts 437, 463-69 (D. Hagman \& D. Misczynski eds. 1978). 330 Originally, New Zealand followed the 1909 English model of betterment recapture. As of August 1973, however, New Zealand is operating under the Property Speculation Tax Act of 1973 which is aimed at land speculators who force up the sale of land value without contributing anything in the way of development value. See Glickfeld \& Hagman, supra note 329, at 459-62. In addition, New Zealand has amended its Land and Income Tax Act of 1954 by adding $\$ 88 \mathrm{AA}(1)$ (ca). This amendment taxes profits which arise from the increase in value attributable to the

rezoning of land, from the likelihood of rezoning, because of development of a particular industry or project in an area or even the gradual encroachment of a town or a city. In these circumstances, as the community has, in a sense, increased the profits of the landowner when he sells, it was considered proper that he in turn should pay income tax back to the community on those profits.

Id. 463.

331 The state of New South Wales, Australia adopted an unearned increment tax in April 1970. Land Development Contribution Act, No. 24, 1970 Stat. N.S.W. 487; Land Development Contribution Management Act, No. 22, 1970 Stat. N.S.W. 334. The tax applied to land in defined areas laying between urbanized Sydney and rural areas. The tax was designed to recapture the unearned increment associated with rezoning. The Minister for Local Government of New South Wales who proposed the betterment levy stated: "those lands which will derive a very considerable benefit in increased value from rezoning, and will require massive public investment in the provision of essential services, should contribute some proportion of this gain towards the public expenditure necessary for their development." Glickfeld \& Hagman, supra note 329, at 454 (quoting parliamentary debates). The tax proved politically unpopular and was repealed after a change of the party in power on December 20, 1973. Id. 458-59.

332 Notions of land value taxation are implicit in California's rural special districts, which have raised substantial tax revenues based solely on land. Special districts are authorized in California under 193 separate statutory provisions. The California controller classifies these districts into 54 types, and 16 of them have land only as their tax base. These "land only" taxes produced in excess of $\$ 40$ million in revenue in 1972-73; that money was used to finance a variety of services, "including water utility, drainage and drainage maintenance, flood control and water conservation, reclamation, streets, levee management and maintenance, soil conservation, water conservation, waste disposal, recreation and park, electric utility, and pest control." Hagman, Land-Value Taxation, in WrNofAIIs For WrPeours 399, 419 (D. Hagman \& D. Misczynski eds. 1978); see id. 415-21. In addition, California has considered, but not adopted, two other Georgist proposals. One bill tied an unearned land value tax to a fund to provide grants to local agencies for open space/recreational land acquisition, and a second proposal would enact a similar tax to fund compensation for landowners precluded from developing their land by reason of governmental laws or regulations. See Glickfeld \& Hagman, supra note 329 , at 475-76. 
Hawaii, ${ }^{333}$ and Vermont. ${ }^{334}$ England appears to have had the most statutory varieties, although most British efforts have had a history of nonenforcement and repeal, reflective of the swings in political power and philosophy from liberal to conservative. ${ }^{335}$

338 From 1963 to 1977, Hawaii had a graded property tax which reflected Georgist ideas. Act 142, 1963 Hawaii Sess. Laws 174 (repealed 1977). While administratively complicated, the tax was basically designed to have improvement taxed at a lesser rate than land. See Hagman, supra note 332, at 411-12.

334 Vermont has enacted a land gains tax both to create a fund for property tax relief as well as to deter land speculation. VT. STAT. ANN. tit. 32, $\$ 10001$ (1973). The rate of the Vermont tax is directly proportional to the percentage of gain and inversely proportional to the holding period. For example, the maximum rate of $60 \%$ is imposed on land held less than one year and sold at a gain of $200 \%$ or more. The minimum rate of $5 \%$ is imposed on land held between 5 and 6 years and sold at a gain of $99 \%$ or less. In Andrews v. Lathrop, 132 Vt. 265, 315 A.2d 860 (1974), the Supreme Court of Vermont upheld the constitutionality of the $\operatorname{tax}$ against an equal protection claim that the classifications providing for no tax after six years were without reasonable basis and that the stated purpose of the tax (property tax relief) was unrelated to the real purpose (the curbing of land speculation). The Vermont Supreme Court found that regardless of the stated purpose, it was a legitimate legislative interest to deter speculation which netted a high gain over a relatively short holding period. Consequently, the holding periods specified by the Act were deemed reasonable. The court also found that the plaintiffs, three land developers and a large land holder, failed to introduce sufficient evidence establishing discrimination between rural and city sellers or between residents and nonresidents.

Because the stated and implied purposes of the Vermont Act are in conflictthat is, taxes which discourage sales will not raise tax revenues if, in fact, sales are reduced in number-it was inevitable that only one of the Act's purposes would be fulfilled. Preliminary indications suggest that the tax has had some effect on reducing the overall rate of land speculation. See Glickfeld \& Hagman, supra note 329 , at $470-75$.

Professors Glickfeld and Hagman note that the District of Columbia, Virginia, Montana, Oregon, Washington, and California have all considered imposing land gains taxes based, at least partially, on the Vermont model. For the most part, these proposals are ostensibly designed to lower the rate of land conversion or speculation. Thus, most of the bills focus on short-term gains. Id. 475-76. Disregarding the concern with land speculation, there is no particular reason to limit the recapture of the unearned increment to merely short-term gains.

335 While both the Labor and Conservative Parties accepted the idea of recapture in principle, they differed as to its administration: the Labor Party wanted it to be a betterment levy administered separately by a land commission, while the Conservatives wanted it to be incorporated into the capital gains tax. See Glickfeld \& Hagman, supra note 329 , at 449 .

Currently, England is experimenting with the Development Land Tax Act of 1976 which includes a betterment levy recapturing upward of $80 \%$ of the development or land value. The Act is reprinted in D. HAGMAN, supra note 19, at 1275-77.

While the taxation of undeveloped land under the Internal Revenue Code (IRC) is beyond the scope of this article, some thought obviously must be given to how the recapture of the unearned increment under the alternative system affects, if at all, the existing tax structure. Undeveloped land under the IRC may be taxed in various ways depending upon its characterization as property held solely for "investment" or for "use in a trade or business" or "primarily for sale to customers." Compare I.R.C. $\$ 1221$ (1976) with id. \$1231. Thus, while gains and losses realized on the sale or exchange of investment property are taxed as capital transactions, short- or long-term as the case may be, the gain on property 
The land value taxation scheme most analogous to the alternative 'system was Australia's Land Development Contribution Act of $1970 .^{336}$ Like the alternative system, the Act applied to essentially undeveloped, but developing, areas. In addition, the tax was calculated on the basis of the difference between a parcel's appraised undeveloped.value and its value at such time as the planning scheme (rezoning) was designated for the property. The primary purpose of the tax was to finance the cost of infrastructure, but the tax proved to be politically unpopular and was repealed three and one-half years later.

\section{(i) Recapturing Windfalls and Eliminating Wipeouts}

While changes in political ideology may partially explain the ups and downs of land value tax programs, much of the their unpopularity can be traced to the fact that the tax has been imposed to recapture the land value windfall without providing any corresponding benefit to the landowner. Specifically, the landowner has been asked to forfeit all, or most, of the land value while being left to face a system of public land use control that has been variously described as "byzantine" ${ }^{337}$ or a "bubbling cacophony of

held primarily for sale to customers (the typical dealer/developer situation) is treated as ordinary income.

It is anticipated that normally a developer will pay the unearned increment under the alternative system, although there is nothing in theory preventing the developer from shifting this cost back to either a farmer or passive investor from whom he purchased the property. Whether or not the developer should be allowed to deduct the amount of unearned increment paid from his federal tax liability is a question related to the underlying purpose of unearned increment recapture. Specifically, if the recapture of unearned increment is directed primarily at a reduction in land speculation, then the developer should not be allowed to deduct the amount of unearned increment from his federal tax liability, for diminishing the latter will tend to negate the dampening effect of the former on land speculation. In contrast, if the unearned increment is being recaptured primarily as a mechanism of recouping community-conferred value, the issue of deductibility comes down to a policy choice reflecting one's attitude toward whether federal revenues should be increased or decreased. If one factors in the additional mystery of tax incidence (who the tax ultimately falls on), the deductibility issue becomes even more complicated. Without addressing these significant issues, the author's predisposition is to allow deductibility.

836 New South Wales Land Development Contribution Management Act and Land Development Contribution Act, Nos. 22, 241970 Stat. N.S.W. 334, 487 (repealed 1973). Despite its similarity to the alternative system, there are significant differences. First, the taxable increment was the difference between a based value and the value of land under a publicly imposed planning scheme. Second, taxable property included both land and improvements. Third, the tax was collected on sale or the final grant of development consent. In comparison, the alternative system does not publicly impose the developed use, taxes only land, and the tax is only due upon development.

337 Address by F. Bosselman, ALI-ABA Land Planning and Regulation of Development Course (March 18, 1976); cited in Hagman, supra note 54, at 20. 
multitudinous edicts." 38s In this regard, the tax has provided an incentive to develop, while public land use control has made development difficult, risky, and often economically infeasible. Professor Hagman has recognized this inequity by suggesting that windfalls be used as a source of compensation for wipeouts, which in many cases are caused by public regulation. ${ }^{832}$ While one may question whether the administrative costs of identifying wipeout victims and monetizing the extent of the wipeout caused by any given regulation is feasible, one cannot fault Hagman's notion that fairness requires "minimizing downside losses and socializing upside gains." 340

One can seriously question, however, whether a system of public regulation that results in extensive downside losses should be perpetuated. The alternative system suggests that it is better to eliminate, rather than mitigate, wipeouts. Once wipeouts are eliminated, the recapture of unearned increment windfalls is highly equitable.

\section{(ii) Land Value Recapture Under the Alternative System}

In recapturing the unearned increment, the alternative system accepts the principles enunciated by Henry George with a few modifications. First, the entire land value is not recaptured, only that amount in excess of the property's agricultural/open space value. The alternative system exempts the agricultural/open space value from taxation in order to give a tax preference to the agricultural/ open space use. ${ }^{341}$

Whether or not agricultural tax preferences under the existing system are equitable and accomplish their preservation purpose is much disputed. ${ }^{342}$ Some have contended that the preference is nothing more than a one-time windfall, likely to be enjoyed by a high-stakes investor as much as a cash-poor farmer. ${ }^{343}$ In any event, say those in opposition to the tax preference, if the farmer has trouble coming up with the tax money, he can either sell to another investor or get a loan. Economically, the tax preference is opposed

338 Hagman, supra note 54, at 20.

${ }^{339}$ Professor Hagman's proposal would also compensate for wipeouts caused by private activity. The alternative system relies upon nuisance law compensation in such circumstances.

340 Hagman, supra note 54, at 24.

341 See generally D. HAGMAN, supra note $17, \S 192$.

842 See supra note 2 (citing materials).

$\$ 43$ Roberts, supra note 2 , at 74 . 
as an insubstantial subsidy to keep land in agricultural use when the developed value of the land is five to ten times greater. ${ }^{344}$

While some of these arguments may have merit in the context of the existing system, they are less applicable to the alternative system. As the previous analysis suggested, one of the drawbacks to a pure land value tax is that it encourages development indiscriminately. An agricultural/open space tax preference solves this problem by exempting the preferred class of property from the pressure to develop. The unearned increment recapture of the alternative system should not create the density problems associated with a pure land value tax because of the alternative system's overall density control embodied in the periodically-revised LUI schedules and the density control available to the community pursuant to an Intensity Modification Contract. Moreover, from an economic standpoint, a tax preference under the alternative system should result in more preservation because the landowner, be he farmer or investor, ${ }^{345}$ is not entitled to the developed use value. Thus, the decision to develop will not be based on a comparison of dramatically different land values but a determination that a market demand exists which makes development profitable even net of the unearned increment.

Finally, the recapture of the unearned increment under the alternative system differs slightly from previous land value recapture programs concerning when the tax is due. Previous schemes have either called for collecting the tax upon sale or development, or for collecting it periodically like other general property taxes. ${ }^{346}$ Under the alternative system, the tax is collected only upon development. Again, this reflects the belief that so long as the land remains in an agricultural or open space use, it should be taxed accordingly, regardless of a change in ownership. Under previous schemes, the tax was collected at the point of sale because of the liquidity created by sale and because the increase in land value was determined in reference to publicly imposed development value. Because the development value is voluntarily selected by

344 Id. 71-72.

345 Recent studies indicate that perhaps as much as $77 \%$ of the farmland in the United States is rented to farmers by land speculators. See Wall St. J., Oct. 6,1981 , at 1, col. 6. Interestingly, the Secretary of Agriculture has suggested a type of land value recapture to reduce the level of speculation. Specifically, the Secretary suggests that the favorable capital gains tax rate only apply to that amount of capital investment required for "the most efficient-sized farm," which he says is about 1,000 acres. Any gain on the investment not attributable to farming would be taxed at higher ordinary income rates. Id. 16, col. 4 .

346 Hagman, supra note 54, table 20-1. 
the landowner at the time of development, this becomes the only relevant tax-triggering event. Thus, the sale of undeveloped land under the alternative system should not result, by itself, in a change to a developed use. In addition, the unearned increment is recaptured only once. This should avoid the problem of annually applied land value schemes which may force older, perhaps historic, structures under the bulldozer because of their inability to produce sufficient income to pay the land value tax..$^{347}$

\section{Conclusion}

The existing land use allocation system for undeveloped land is unfair, inefficient, inflexible, and uncertain. The alternative free enterprise development system suggests that deregulating the process will substantially overcome these shortcomings.

The alternative system promotes procedural fairness by redirecting citizen/neighbor participation toward policymaking, rather than application. Removing the neighbor from policy application prevents the misuse of land use controls as devices for preserving the status quo and excluding newcomers. Distributional fairness is enhanced through the recapture of the unearned increment traditionally associated with development permission under the existing system. Correlatively, reducing public discretion over private development minimizes the likelihood of being wiped out by public control and the motivation for corrupt behavior. This is underscored by linking public control of density and public improvement with the amount of unearned increment recaptured.

The efficiency gains of the alternative system relate primarily to lowering the administrative costs of land use regulation. The alternative system consolidates control in one agency. With one exception, that agency is limited to the ministerial administration of the four density schedules established by the local legislative body. The one exception relates to the negotiation of Intensity Modification Contracts. This device has been retained within the alternative system as a mechanism of public control within, rather than opposed to, the market. Prevention costs should also be less under the alternative system because of the substitution of the general deterrence of nuisance law for the specific, pre-set regulation of the existing system. While public improvement is specified under the alternative system, it is done on a sensitive, case-by-case basis. 
Because the alternative system is premised upon individual decisionmaking, it is highly flexible. The location of uses, size of lots and structures, and building and site design are decisionsall placed with the landowner. Subject to the restrictions of the building code and express or implied warranties of fitness, the selection of construction materials is also an individual matter.

The proposed alternative brings certainty to the land development process by replacing the ambiguous and economically wasteful vesting rules of the existing system with the automatic vesting implicit in the landowner's selection of a land use intensity rating. Moreover, although the specific public facility requirements are not known in advance of the administrative determination of the Public Improvement Contract, the maximum cost to the landowner is known in advance in the form of the unearned increment, which should be capable of reasonable appraisal.

The alternative system demarcates the appropriate concerns of public and private decisionmaking. Public land use control is limited to defining acceptable community standards for population density and safety in terms of public improvement. Private decisions determine everything else.

Public improvement decisions are best made publicly because of the natural limits on the information and economic motivations of private decisionmakers. Clearly acknowledging public control in this context should eliminate many of the deficiencies associated with the existing system and should reduce markedly the possibility of negative externalities from private development.

Private improvement decisions are best made privately. The deregulation of the land use allocation process represented by the alternative system requires an abandonment of the strained fictions and evasions of the existing system that permit wholesale interference in the land market motivated by the desire for social, economic, and racial segregation and hidden behind a generalized and often spurious concern with the "public interest." The public interest is a vacuous concept designed to prevent the disclosure of the actual private interests being served. Recognizing that the use of land is essentially a private matter should right the failings of the existing system and restore the individual freedom that has been all too frequently sacrificed beneath the vague banner of the general welfare. 